\title{
Clinical studies on hereditary thrombophilia : a focus on resistance to activated protein $\mathrm{C}$ (factor V:Q506)
}

Citation for published version (APA):

Martinelli, I. M. (1997). Clinical studies on hereditary thrombophilia : a focus on resistance to activated protein C (factor V:Q506). [Doctoral Thesis, Maastricht University]. Universiteit Maastricht. https://doi.org/10.26481/dis.19971217im

Document status and date:

Published: 01/01/1997

DOI:

10.26481/dis.19971217im

Document Version:

Publisher's PDF, also known as Version of record

\section{Please check the document version of this publication:}

- A submitted manuscript is the version of the article upon submission and before peer-review. There can be important differences between the submitted version and the official published version of record.

People interested in the research are advised to contact the author for the final version of the publication, or visit the DOI to the publisher's website.

- The final author version and the galley proof are versions of the publication after peer review.

- The final published version features the final layout of the paper including the volume, issue and page numbers.

Link to publication

\footnotetext{
General rights rights.

- You may freely distribute the URL identifying the publication in the public portal. please follow below link for the End User Agreement:

www.umlib.nl/taverne-license

Take down policy

If you believe that this document breaches copyright please contact us at:

repository@maastrichtuniversity.nl

providing details and we will investigate your claim.
}

Copyright and moral rights for the publications made accessible in the public portal are retained by the authors and/or other copyright owners and it is a condition of accessing publications that users recognise and abide by the legal requirements associated with these

- Users may download and print one copy of any publication from the public portal for the purpose of private study or research.

- You may not further distribute the material or use it for any profit-making activity or commercial gain

If the publication is distributed under the terms of Article $25 \mathrm{fa}$ of the Dutch Copyright Act, indicated by the "Taverne" license above, 


\section{CLINICAL STUDIES ON HEREDITARY THROMBOPHILIA}

$A$ focus on resistance to activated protein $C$ (factor $V: Q 506$ ) 
Martinelli, Ida Marianna

Clinical studies on hereditary thrombophilia:

a focus on resistance to activated protein C (factor V:Q506)

Ida Marianna Martinelli

Thesis Madstricht - with ref.

ISBN $90-9011197-2$

Subjects headings: blood coagulation/thrombosis/

APC resistance/factor V:Q506/risk factors 


\section{CLINICAL STUDIES ON HEREDITARY THROMBOPHILIA}

$A$ focus on resistance to activated protein $C$ (Factor V:Q506)

\section{PROEFSCHRIFT}

Ter verkrijging van cle graad van doctor ann de Universiteit Maastricht op gezag van de Rector Magnificus, Prof. Mr. M.J. Cohen, volgens het besluit van het College van Decanen, in het openbaar te verdedigen op woensdag 17 december 1997 om 12.00 uur

door

Ida Marianna Martinelli

Geboren te Milaan 
Promotores:

Prof. Dr. H.C. Hemker

Prof. Dr. P.M. Mannucci, University of Milan

Beoordelingscommissie

Prof. Dr. J. Troost (voorzitter)

Prof. Dr. M. Berrettini, University of Perugia

Prof. Dr. J.P.M. Geraedts

Prot. Di. W. Th. Hermens

Prof. Dr. P.B. Soeters

Prof Dr. J.P. Vandenbroucke, Rijksuniversiteit Leiden

Cover: "Art that heats". Protective scroll (detail), parchment. Callection: Musée National des" Ars d'Afique et d'Oceanie, Paris.

This thesis has been prepared at Angelo Bianchi Bonomi Hemophilia and Thrombosis Center, IRCCS Ospedale Maggiore, University of Milan, Italy

Financial support by Rhône-Poulenc Rorer S.p.A., Origgio (VA), Italy, for the publication of this thes is is gratefully acknowledged 
Alla menoria di mio padre

A mia madre per la sua saggezza e a Massimo per il suo anore 


\section{Acknowledgements}

\section{Chapter 1}

General Introduction

Page 11

\section{Chapter 2}

\section{MUTANT FACTOR VINITALIANS}

Frequency of factor V Arg506Gln in Italians

Page 20

Thromb Haemost 1996;75:694

Prevalence of mutant factor $\mathrm{V}$ in Italian

Page 23

patients with hereditary deficiencies of

antithrombin, protein $\mathrm{C}$ or protein $\mathrm{S}$

Thromb Haemost 1996; 75:694-5

\section{Chapter 3}

COAGULATION DEFECTS ASSOCIATED WITH INHERITED THROMBOPHILIA

Resistance to activated protein $\mathrm{C}$ in unselected

patients with arterial and venous thrombosis

Am J Hematol 1997;55:59-64

Differential risks of thrombosis for four coagulation

Page $\quad 39$

defects associated with inlerited

thrombophilia. A study of 150 families

Ann Intern Med, submitted

\section{Chapter 4}

Heightened thrombin generation in individuals 


\section{Chapter 5}

RISK FACTORS FOR RARE MANIFESTATIONS

OF VENOUS THROMBOSIS

Factor $\mathrm{V}$ gene mutation is a risk factor for

Page 64

cerebral venous thrombosis

Thromb Haemost 1996;75:393-4

Oral contraceptives are a risk factor for

Page 70

cerebral vein thrombosis

Thromb Haemost 1996;74:477-8

Risk factors for deep venous thrombosis

Page 72

of the upper extremities

Ann Intern Med 1997; 126:707-11

Low prevalence of factor V:Q506 in patients

Page 83

with isolated pulmonary embolism

Thromb Haemost 1997;77:440-3

\section{Chapter 6}

Arg506Gln factor $\mathrm{V}$ mutation and cerebral ischemia in the young

Stroke 1996;27:1697-8

\section{Chapter 7}

Hyperhomocysteinemia as a risk factor for

deep-vein thrombosis

Page 95

N Engl J Med 1996; 335:974.5

\section{Chapter 8}

Summary and Perspectives

Page 99

\section{Curriculum Vitae}




\section{Acknowledgements}

This work was carried out at the "Angelo Bianchi Bonomi" Hemophilia and Thrombosis Center, IRCCS Ospedale Maggiore and University of Milano, in 1995-97. The publication of this thesis has been financed by Rhône-Poulenc Rorer, which is gratefully acknowledged.

First of all I would like to thank my supervisor Prof. Pier Mannuccio Mannucci for his incentives and for infusing me with his enthusiasm for research. His lifelong experience and constructive criticism have been the basis of my work.

My deepest thanks to Prof. Marco Cattaneo, who has given invaluable scientific support and enormous help in discussing new ideas. He is a person I always can rely on and ask all sort of questions; other than competent guidance, he has given me the support of a good friend.

I also thank all the people working with me at the Clinic and at the Epidemiology Unit for their interest in my work, collaboration and friendship; they have been all very precious for me. Furthermore, I am grateful to all the staff working in the labs for their competence and skilful assistance.

I would also express my thanks to all the patients at the Thrombosis Center and to their friends or partners who came as healthy controls. Without them, there would be no thesis.

Finally, I want to thank all my friends for their support; my mother Marina and my dearest Massimo are thanked for being there, helping me with their encouragement and optimistic attitude during this period. 


\section{Chapter 1}

\section{GENERAL INTRODUCTION}

Venous thrombosis is a serious, potentially lethal health problem, which has an overall incidence of 1 in 1000, being rare in the young and more frequent with advancing age. This tendency to thrombosis is called thrombophilia and, when a genetic explanation is likely, it is called hereditary thrombophilia: occurring in families, often causing thrombosis among family members at a young age and without apparent causes, and often recurring. This term acknowledges the presence of an inherited factor that itself predisposes thrombosis but, due to the episodic nature of thrombosis, requires interaction with other factors (inherited or acquired) before the onset of the disease. In fact, the development of thrombosis is often thought to be caused by interaction between genetic and acquired factors, the latter being best recognized in advancing age, major surgery, immobilization, pregnancy, puerperium, oral contraceptives, malignancies and the antiphospholipid syndrome.

The concept of hereditary thrombophilia has changed in the past decades, with progress in the knowledge of coagulation mechanisms. It was originally based upon early presentation of thrombosis, usually associated with an inherited phenotypic abnormality of one of the naturally occurring inhibitors (antithrombin, protein $\mathrm{C}$, protein S). In 1965 , the first kindred with antithrombin deficiency was described (1) and for many years the deficiency of this naturally occurring anticoagulant protein was the only identified cause of inherited thrombophilia. In the early 1980s the identification first of protein C deficiency $(2)$ and then of protein S deficiency $(3,4)$ was a crucial step towards the knowledge of additional causes of inherited thrombophilia.

Biochemically, the two principal endogenous anticoagulant pathways, the antithrombin-heparan sulphate pathway and the protein C/protein $\mathrm{S}$ pathway, involve close interactions between plasma proteins and the endothelial cell surface (Figure 1). The presence of heparin-like molecules on the endothelial cell surface accelerates antithrombin-dependent inactivation of coagulation proteases, and the endothelial cell membrane 


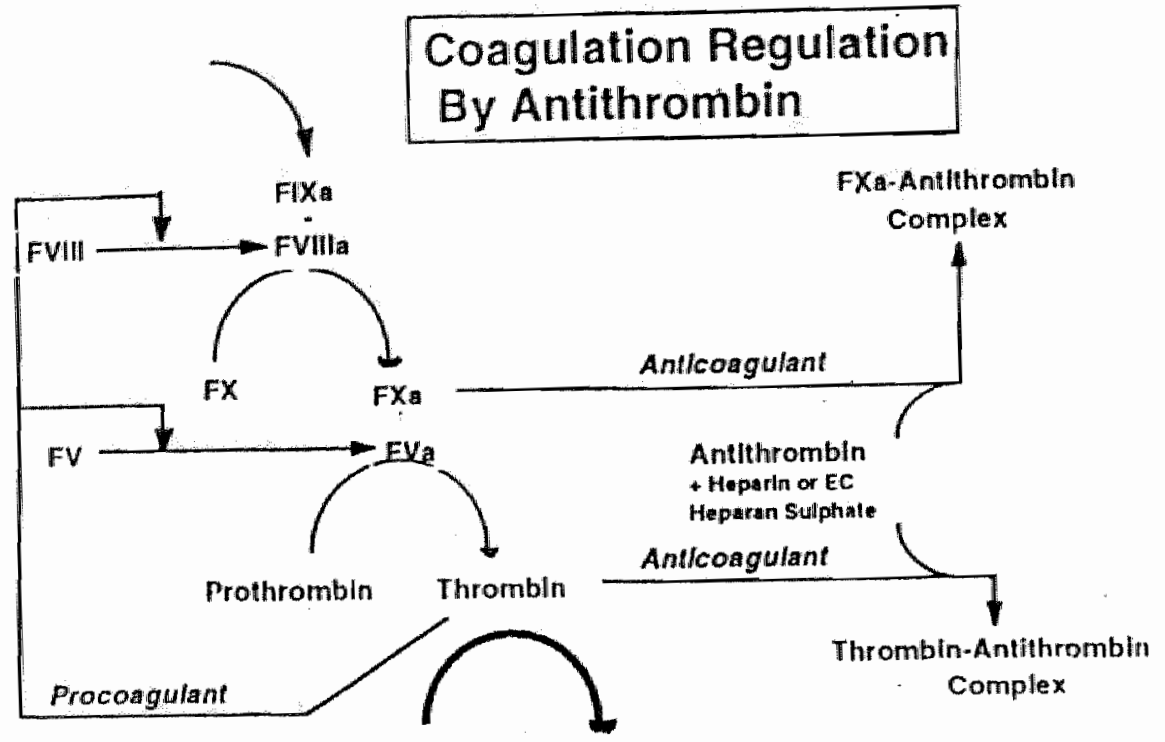

Fibrinogen Fibrin
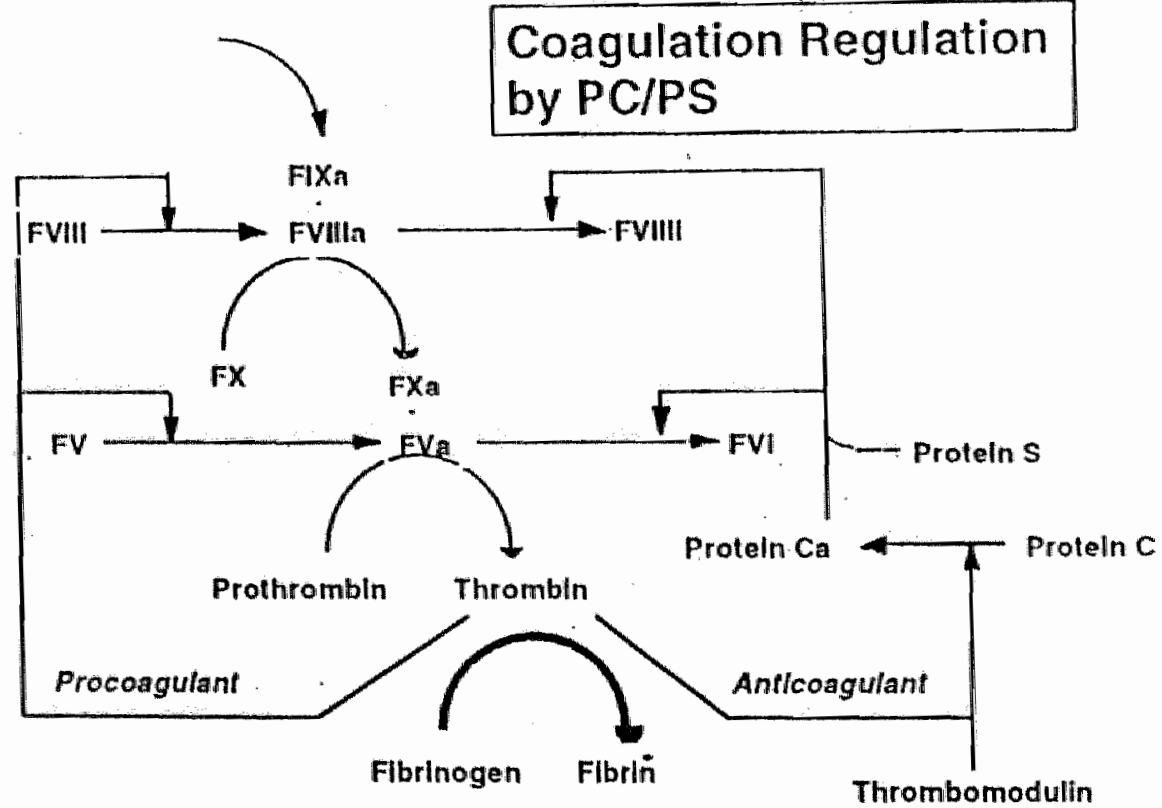

Fugure 1. To the lef of the frgare is a simplified wew of the congration cascade, showing the procoagulant loops by which

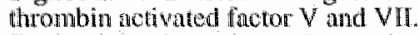

To the righ, the anticonguant pathways by wheh excessive activation of coaguhtion is prevented 
protein thrombomodulin binds thrombin with high affinity, thereby altering its substrate specificity. Thrombin bound to thrombomodulin loses its procoagulant activity and becomes a potent activator of protein $\mathrm{C}$.

Antithrombin, protein $\mathrm{C}$ and protein $\mathrm{S}$ deficiencies account altogether for only less than $15 \%$ of selected cases of early-onset and/or recurrent venous thrombosis and for less than $10 \%$ of unselected cases of venous thrombosis (5). In 1993 it was observed that plasma samples from certain individuals with inherited thrombophilia were in part resistant to the anticoagulant action of activated protein $\mathrm{C}$ (APC), which normally inactivates the activated factors V and VIII (6). A genetic defect was suggested by a positive family history and by the identification of APC resistance in several family members. To elucidate the molecular background, several mechanisms that theoretically could cause the defect were investigated. A mutated serpin functioning as an efficient APC inhibitor, functional protein S deficiency, mutation in the genes for factor VIII or $\mathrm{V}$ resulting in APC resistant molecules, and the involvement of an unknown APC cofactor were judged to be potential mechanisms for inherited APC resistance (6). The answer came one year later, when to elucidate the nature of a protein fraction of normal plasma able to correct APC resistance, normal plasma was subjected to protein fractionation procedures, and a plasma protein that corrected the APC resistance in a dose-dependent manner was isolated and found to be identical to factor V (7). Linkage studies in two large families, one from the Netherlands and the other from Sweden, supported the concept that APC resistance was caused by a factor $V$ gene defect $(8,9)$, and a single point mutation was found to co-segregate with $\mathrm{APC}$ resistance $(8,9)$. The mutation involved a $\mathrm{G}$ to $\mathrm{A}$ transition of nucleotide 1691 in exon 10, which predicts the synthesis of a variant factor $\mathrm{V}$ molecule (factor V:Q506, with an Arg instead of Gln at position 506, also named factor $V$ Leiden). Since the mutation is located in one of the APC cleavage sites of factor $V$, it causes a hypercoagulable condition by slowing the inactivation of activated factor $V$ by APC (10,11). This is the most frequent cause of inherited thrombophilia, being found in about $50 \%$ of families with thrombophilia and in $20 \%$ of consecutive patients with venous thrombosis $(12,13)$. In contrast to other genetic defects associated with thrombosis whose prevalence in the general population is less than 1\%, the prevalence of factor V:Q506 has been found up to $7 \%$ in Caucasian populations, but a much lower prevalence (around 0\%) has been reported in the Japanese and other Eastern populations $(14,15)$. Due to the high prevalence of APC resistance in the general population, its combination with other genetic defects is not exceptional (16-19), even though in Italy it is relatively uncommon (20).

The most common clinical manifestations of antithrombin, protein $\mathrm{C}$ or protein $\mathrm{S}$ deficiency are deep vein thrombosis of the lower limbs with or without pulmonary embolism, that account for approximately $90 \%$ of all thrombotic episodes. Unusual sites of venous thrombosis, such as the mesenteric or cerebral veins, account for less than $5 \%$ 
of the total episodes in patients with antithrombin, protein $\mathrm{C}$ or protein $\mathrm{S}$ deficiency. In antithrombin deficiency, the overall risk of thrombosis is considered greater than in protein $\mathrm{C}$ or protein $\mathrm{S}$ deficiency (21). On the other hand APC resistance is associated with a lower thrombotic tendency than antithrombin, protein $\mathrm{C}$ or protein $\mathrm{S}$ deficiency, as indicated by the higher prevalence of asymptomatic individuals beyond the young age $(22,23)$ and by the higher frequency of relatively mild thrombotic symptoms (24). In fact, although deep vein thrombosis of the lower limbs is the most common symptom also in APC-resistant subjects, a mild thrombotic manifestation such as superficial thrombophlebitis is more frequent in APC resistance than in the other three defects. There is no clear evidence that antithrombin, protein $C$, protein $S$ deficiency or APC resistance increase the risk of arterial thrombosis (12). Another step forward in the knowledge of thrombophilia was made during the last few years with the identification of hyperhomocysteinemia as a risk factor for venous thromboembolism. It was already known that mildly increased plasma homocysteine levels were associated with arterial thrombosis (stroke, myocardial infarction, peripheral arterial disease, and extracranial carotid artery stenosis), independently by the presence of other risk factors like smoking, hyperlipidemia, hypertension, and diabetes (25-28). Hyperhomocysteinemia as a risk factor for venous thromboembolism was first described in $19 \%$ of patients with juvenile venous thrombosis, and their family history showed that in most cases the abnormality was inherited (29). This finding was widely confirmed by further studies that supported the role of hyperhomocysteinemia in the development of premature and/or recurrent thromboembolic disease (28). The reported prevalence of the defect in unselected patients with a first venous thrombosis was $10 \%$ and that in the general population was approximately $5 \%(30)$. Homocysteine plasma levels are strictly dependent on vitamin status, and an inverse relationship between homocysteine and folate or vitamin B 12 plasma concentrations has been shown (28). Elevated homocysteine is also associated with inherited enzymatic defects (25), other than with low plasma levels of folate, vitamin B 12 or vitamin B6 (26). Homocysteine intracellular metabolism occurs through remethylation to methionine or transulphuration to cysteine (Figure 2). The key-enzymes are cystationine- $\beta$-synthase, involved in the transulphuration pathway, and methylenetetrahydrofolate reductase, involved in the remethylation pathway. Gene defects in both of these metabolic enzymes are implicated in mild hyperhomocysteinemia, and a recently described mutation with thermolability of methylenetetrahydrofolate reductase may in the homozygous state be a significant and frequent cause for mild hyperhomocysteinemia (31).

The mechanisms by which hyperhomocysteinemia contribute to atherogenesis and thrombogenesis are not completely understood, and have been reviewed recently (28). In vivo studies in baboons have shown that hyperhomocysteinemia causes a toxic effect on endothelial cells, smooth-muscle-cell proliferation, and intimal thickening. In vitro 


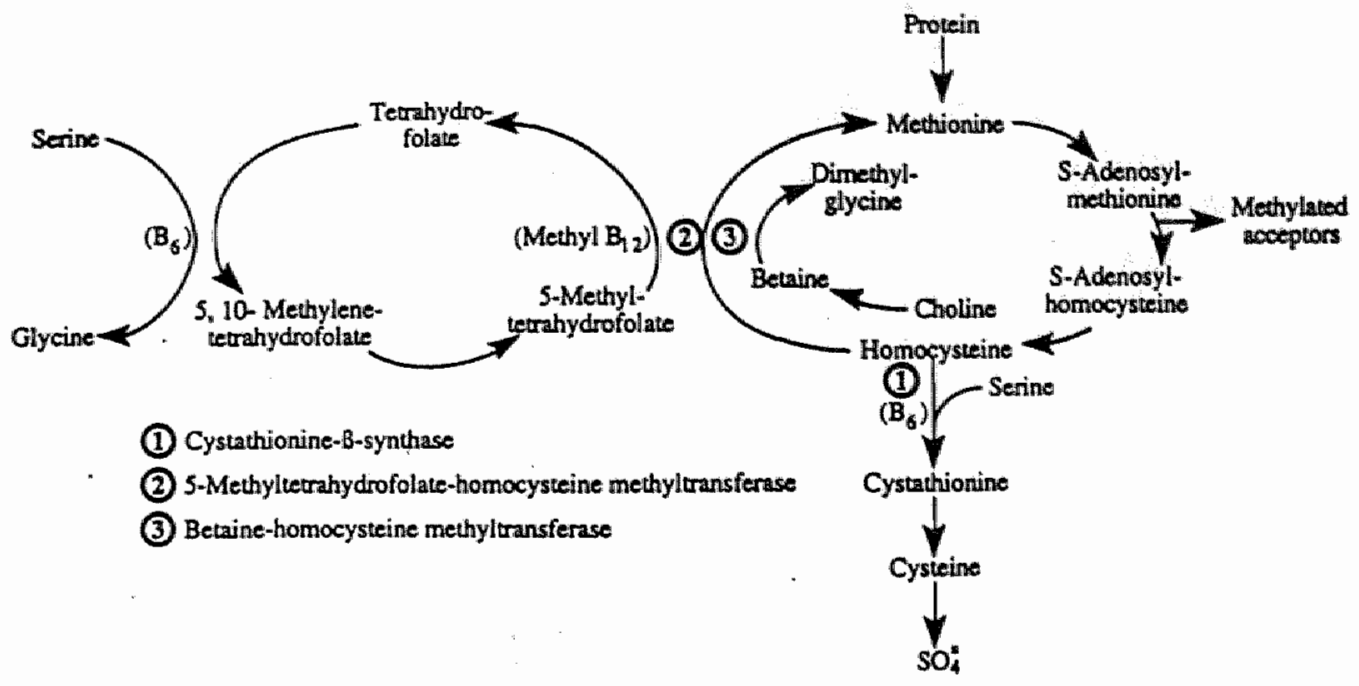

Figure 2. Pathways for homocysteine metabolism: 1: methionine synthetase; 2 : methylenetetrahydrotolnte reductase: 3: betaine-homocysteine methyltmanferase; 4 : cystathionine- $\beta$-synthetase; Cbl: cobalamine;

PLP: pyridoxal-5"-phosphate.

studies have shown that the toxic effect of high homocysteine concentrations on endothelial cells also result in increased platelet adhesion, activation of factor $\mathrm{V}$ and interference with protein $\mathrm{C}$ activation and thrombomodulin expression, impaired generation of nitric oxide and prostacyclin (which are potent antiaggregating and vasodilating agents), inhibition of tissue plasminogen activator, induction of tissue factor activity, and suppression of the expression on the vessel wall of the anticoagulant substance heparan sulphate. However, it must be born in mind that most in vitro effects of hyperhomocysteinemia are seen when plasma concentrations are highest, usually at least one order of magnitude greater than the concentration found in patients with homozygous homocystinuria. Although further experiments are required, it is likely that elevated homocysteine exerts its effects on more than one system.

Very recently, a novel cause of hereditary thrombophilia has been discovered: it is a nucleotide change (a $G$ to $A$ transition) at position 20210 in the sequence of the 3 '-untranslated region of the prothrombin gene (32). The prevalence of this genetic variation is $2.3 \%$ in the general population, $18 \%$ in selected thrombophilic patients and $6.2 \%$ in unselected consecutive patients with a first episode of venous thrombosis. The risk of thrombosis in carriers of the variant prothrombin is moderate, being 2.8 times higher than in non-carriers. A preliminary analysis of our patient's population and healthy 
controls (unpublished data) showed similar results to those reported by the Dutch investigators. The identification of this novel coagulation defect is too recent to be included in the works contained in this thesis.

The purpose of the work contained in this thesis was to gain more insight into the epidemiology and pathophisiology of venous thrombosis, in particular, with respect to the role played by APC resistance (factor V:Q506). Its role in patients with various thrombotic manifestations, venous or arterial, and the risk carried by itself or in association with other genetic or circumstantial situations have been investigated.

The thesis has been structured as follows: the prevalence of APC resistance in the Italian general population and the co-segregation of the defect with other inherited thrombophilic defects is first presented (Chapter 2). Subsequently, we investigated the prevalence of APC resistance in consecutive unselected patients with arterial and venous thrombosis (Chapter 3 ) and we estimated the risk of thrombosis associated with the defect in a large family study, making a direct comparison with the other inherited thrombophilic defects (antithrombin, protein $\mathrm{C}$ and protein $\mathrm{S}$ deficiency). Heightened thrombin generation was found in individuals with APC resistance, similarly to what previously observed in patients with other thrombophilic defects (Chapter 4). To investigate whether or not coagulation defects predisposing to thrombosis play a different pathogenetic role in various sites, studies on patients with rare thrombotic manifestations, such as cerebral vein thrombosis, deep vein thrombosis of the upper extremity and isolated pulmonary embolism, were performed (Chapter 5). The association between inherited thrombophilia and arterial thrombosis is uncertain and, if it exists, weaker than that with juvenile venous thrombosis. In order to evaluate whether or not APC resistance was associated with an increased risk to develop cerebral ischemia at a young age (i.e., in the absence of atherosclerotic plaques) a case control study was carried out (Chapter 6). It is well known that hyperhomocysteinemia is a risk factor for arterial thrombosis. In 1994, we were the first to demonstrate that hyperhomocysteinemia was associated not only with an increased risk of arterial thrombosis, but also of venous thrombosis. In our opinion, the diagnosis of hyperhomocysteinemia should be based on measurements of plasma homocysteine levels both after overnight fasting and after an oral methionine loading. Prevalence of hyperhomocysteinemia in patients with deep vein thrombosis and healthy controls, and the importance of methionine loading are shown (Chapter 7).

\section{REFERENCES}

1. Egberg O. Inherited antithrombin III deficiency causing thrombophilia. Thromb Diath Haemorth 1965,13,516-30

2. Griffin J, Ewat $B$, Zimmermann $T$, Kletss $A$, Wideman C. Deficiency of protein $C$ in congenital thrombotic disease, JCllin Inwest 1981;68:1370-3 
3. Comp P. Esmon C. Recurnent venous thromboembolism in patients with a partal deficiency of protein S. N Engl J Med 1984:311:1525-31

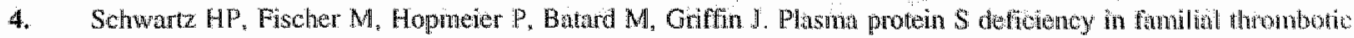
diserse. Blood 1984:64:1297-300

5. Allart CF, Brièt E. Familial venous thrombophilia. In: Bloom AL, Forbes CD, Thomas DP, Tuddenhan EOD (eds); Haemostasis and Thrombosis. London, UK., Churchill Livingstone 1994, pl 349

6. Dahlbäck B, Carlsson M, Skensson PJ. Familial thrombophilia due to a previously unecognized mecganism characterized by poor anticoagulant response to activated protein C. Proc Natl Acad Su USA 1993;90:1004-8

7. Dahlbaick $B$, Hildebrand $B$. Resistanxee to activated protein $C$ is contected by anticoagulant colaclor activity found to be a property of factor V. Proc Natl Acad Sci 1994:91:1396-400

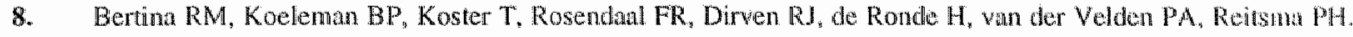
Mutation in blood coagulation factor $\mathrm{V}$ associated with resistance to activated protein C. Nature 1994:369:64-7

9. Zöller B, Dablbäck B. Linkage between inheribed resistance to activated protein $C$ and frotor $V$ gene muntion in venous thrombosis. Lancet 1994:343:1536:8

10. Grifin JH, Heeb MU, Kojima $Y$, Fenandez JA, Hackeng TM, Greengard JS. Activaled protein C resistance: molecular mechanisms. Thromb Haemost 1995;74:444-8

11. Kalafatis $M$, Bertina RM, Rand MD, Mann KG. Characterization of the molecular defect in factor V R $506 \mathrm{Q}$. J Biol Chem 1995;270:4053-7

12. De Stefano V. Finazzi G, Mannucci PM. Inherited thrombophilia: pathogenesis, elinical syndromes, and management. Blood 1996;87:3531-44

13. Lane DA, Marnucci PM, Bauer KA, Bertina RM, Bochov NP, Boulyjeakow W, Chandy M, Dahlbaick B, Ginter EK, Miletich JP, Rosendaal FR, Seligsohn U. Intuerited thrombophilia; part I. Thromb Haenost 1996;76:651-62

14. Rees DC, Cox M, Clegg JB. World distribution of factor V Leiden. Lincet 1995;346:1133344.

15. Mannucci PM, Duca F, Peywandi F, Tagliahue L, Merati G, Martinelli I, Cattaneo M. Frecuency of fractor V Argso6 Gln in italians. Thromb Haemost $1996 ; 75: 694$

16. Koeleman BPC, Reitsma PH, Allaart CF, Bertina RM. Factor $Y$ Leiden: an additional risk factor for thrombosis in protein $C$ deficient families. Blood 1994; 84:103:-5

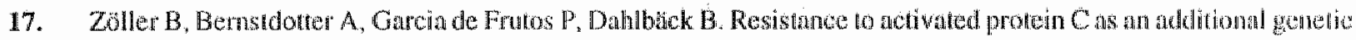
risk factor for thrombosis in hereditnry deficiency of protein S. Blood $1995 ; 85,3,518-23$

18. Koeleman BPC, wan Rumpt D, Hamulyak K, Reitsma PH, Bertina RM. Factor V Leiden an additional fisk lintor for thrombosis in protein $S$ deficient families? Thromb Haenost 1995;74:580-3

19. van Bowen HH, Reisma PH, Rosendaal FR, Bayston 'TA, Chowdhury V, Bauer KA, et al. foctor V Leiden (PFV $\mathrm{R} 506 \mathrm{Q})$ in families with inherited antithombin deficiency. Thromb Hacmost 1996;75:417-21

20. Martingtli I, Magatelli R, Cattaneo M, Marmeci PM. Prevalenco of mutant factor $V$ in Italjam paticns with hereditary deficiencies of antithrombin, protein $C$ or protein S. Thromb Haemost 1996;75694

21. Finazzi $G$, Barbui $T$. Different incidence of venous thrombosis in patients widh inherited deficiency of antithrombin 111. protein C and protein S. Thromb Hacmost 1994;71:15 19

22. Svensson PJ, Dahlbäck B. Resistance to activated protein $C$ as a basis for venous thrombosis. $N$ Engl I Med $1994: 330: 517-22$

23. Zöller $B$, Svensson PI, He $X_{n}$ Dahlback. B. Identification of the same factor $V$ gene mutation in 47 oul of 50 thrombosis-prone families. Blood 1994;94:3444-8

24. Martinetli I, Mannucci PM, De Stefano V, Taioli E, Rossi V, Crosti F, Paciaroni K. Leone G, Faioni EM Differential risks of thrombosis for four coagutation defects associated with inheri ted thrombophilia. Ann Iniem Med, in press 
25: Mainow MR. Homocysteyine and arterial occlusive disedses. In Med 1994,236:603

26. Sellub J, Jacques PF, Boston AG, D Agostino RB, Wilson PWF, Belariger AJ, OLesry DH, Wolf PA, Schaeffer

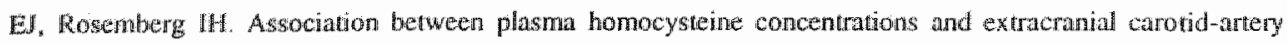
stenosis. N Engl J Med 1995;332,286-91

27. Mudd SH, Levy HL, Skovby F. Disorders of transulfuration. In: the ntetabolic basis of inherted disease. Scriver CR, Benudet AL, sly WS, Valle D (eds). McGraw Hill, Mew York 1989; pp693

28. D Angelo A, Senlub J. Homocysteine and thrombotic disease. Blood 1997;90:1-11

29. Falcon CR, Caitaneo M, Panzeri D, Martineli I. Mannuci PM. High prevalence of layperhomocysteinemia in patients with jwvenille venous thrombosis. Arteriosel Thromb 1994; 14:1080-3

30: den Heijer M, Koster T, Blom HI, Bos GMI, Briet E, Reitsma PH, Vandenbroucke JP, Rosendall FR. Hyperhomoeystememia as a risk Gactor for deep vein thrombosis. N Engl J Med 1996;334:759-62

31. Fiosst P. Blom HI, Milos R, Goyette P. Sheppard CA, Mathews RG, Boers GHI. A candidate genetic risk factor for vaschlar disense: a common mutation in methylentetrafolate reductase. Nathe Genetics $1995 ; 10: 111-3$

32. Poort SR, Rosendaal FR, Reitsma PH, Bertina RM. A common genetic variation in the 3'-untranslated region of the prothombin gene is associated will elevated plasma prothombin levels and an increase in venous hrombosis. Blood 1996;88:3698-703 


\section{Chapter 2}

\section{MUTANT FACTOR V IN ITALIANS}

Frequency of factor $\mathrm{V}$ Arg $506 \mathrm{GIn}$ in Italians

Thromb Haemost 1996; 75: 694

Prevalence of mutant factor $V$ in Italian patients with hereditary deficiencies of antithrombin, protein $\mathrm{C}$ or protein $\mathrm{S}$ Thromb Haemost 1996; 75: 694-5 


\section{FREQUENCY OF FACTOR V Arg506GIn IN ITALIANS}

Pier Mannuccio Mannucci, Francesca Duca, Flora Peyvandi, Liliana Tagliabue, Giuliana Merati, Ida Martinelli, Marco Cattaneo

"A. Bianchi Bonomi" Hemophilia and Thrombosis Center, Institute of Internal Medicine, IRCCS Ospedale Maggiore, University of Milan, Italy

Thromb Haemost 1996;75:694 
In a study of 49 Italians Rees et al (1) found there were no cartiers of the coagulation factor $\mathrm{V}$ mutation (substitution of Arg 506 with GIn) which causes resistance to activated protein $\mathrm{C}$. The blood samples had been obtained initially for community-based surveys of hemoglobinopathies and the sex and age of the subjects was not reported. In view of the small number of individuals studied, the findings of Rees et al should not be taken as evidence that the factor $V$ mutation is absent or has a particularly low frequency in Italy. Using PCR analysis (2), we have looked for the mutation in 344 individuals from Northern Italy who were chosen as controls for our studies on the frequency of the mutation in patients with thrombotic diseases and who have been divided into 4 groups (Table 1).

Table 1. Factor V Arg506GIn in 344 Italians

\begin{tabular}{lccccc}
\hline $\begin{array}{l}\text { Group } \\
\text { Composition }\end{array}$ & No & $\begin{array}{c}\text { Median age } \\
\text { (range) }\end{array}$ & $\begin{array}{c}\text { Males/ } \\
\text { fernales }\end{array}$ & $\begin{array}{c}\text { Heterozygotes } \\
\text { s }\end{array}$ & $\begin{array}{c}\text { Allele } \\
\text { frequency } \\
(\%)\end{array}$ \\
\hline $\begin{array}{l}\text { Clinical and laboratory staff } \\
\begin{array}{l}\text { Community population } \\
\text { Milan) }\end{array}\end{array}$ & 59 & $40(25-68)$ & $16 / 43$ & 3 & 2.5 \\
$\begin{array}{l}\text { Community population } \\
\text { Vicenzan) }\end{array}$ & 75 & $63(31-75)$ & $15 / 60$ & $2 / 48$ & 1.4 \\
$\begin{array}{l}\text { Non-thrombotic } \\
\text { hospital }\end{array}$ & 100 & $42(26-61)$ & $86 / 14$ & 1 & 1.3 \\
$\begin{array}{l}\text { admissions } \\
\text { Total }\end{array}$ & 344 & $43(19-75)$ & $179 / 165$ & 9 & 1.0 \\
\hline
\end{tabular}

In 59 members of the clinical and laboratory staff of the University Institute of Internal Medicine, the frequency of the abnormal altele was $2.5 \%$. In 1.10 individuals from the community of Milan (North-Western Italy), chosen as sex-and age-matched controls for a study of out-patients referred to our institution with suspected inherited thrombophilia, the allele frequency was $2.4 \%$. In 75 individuals from the community of Vicenza (North Eastern Italy), chosen as controls for a study of patients with cerebral vein thrombosis, the allele frequency was $1.3 \%$. In 100 patients admitted to hospital for non-thrombotic heart disease and chosen as controls for a study of young patients with myocardial infarction, the allele frequency was $\mathbb{\%}$. In the entire group of 344 Italians the allele frequency was $1.3 \%$ (95\% C.I. 0.6-2.6) (Table). Our findings indicate that the factor $V$ mutation which is very frequent in Northern Europeans, is also present in Southem Europeans. The results are consistent with allele frequencies of $7 \%$ found by Rees et al (1) in Greeks and Greek Cypriots and of $1 \%$ found by Emmerich et al (3) in the population of South-Western France. 


\section{REFERENCES}

1. $\mathbb{R e e s} D C_{b}$ Cox $M_{,}$Clegg JB. Wonld distribution of factor V Leiden. Lancet 1995; 346:1133-1134.

2. Bertina RM, Koeleman BPC, Koster T, Rosendal FR, Dirven RJ, de Ronde $H_{*}$ wan der Velden PA, Reitsma PH. Mutation in blood coagulation factor $V$ associated with resistance to activated protein C. Nature 1994; 369:64-67.

3. Emmerich J, Poirier O, Evans A, Marques-Vidal P, Arveiler D, Luc G, Aulach M, Cambien F. Myocardial infarction. Arg 506 to Ghi factor V mutation, and actiwated protein C resistance. Lancet 1995; 345: 321. 


\section{PREVALENCE OF MUTANT FACTOR V IN ITALIAN PATIENTS WITH HEREDITARY DEFICIENCIES OF ANTITHROMBIN, PROTEIN C OR PROTEIN S}

Ida Martinelli, Renata Magatelli, Marco Cattaneo, Pier Mannuccio Mannucci

"A.Bianchi Bonomi" Hemophilia and Thrombosis Center, Institute of Internal Medicine, IRCCS Ospedale Maggiore,

University of Milan, Italy

Thromb Haemost 1996;75:694-5 
Resistance to activated protein C (APC) is caused by the substitution of arginine with glutamine at position 506 in the factor $\mathrm{V}$ gene, involving one of the two cleavage sites by $A P C$ of activated factor $V$ which is rendered partially resistant to inactivation (1). APC resistance is detected in $20-40 \%$ of unselected patients with venous thrombosis, and in 2-7\% or more of the general population (2). The associated increase in the risk of venous thrombosis is estimated to be 5- to 10-fold (3). Previous studies on Swedish and Dutch populations showed a high prevalence of mutant factor $\mathrm{V}$ in symptomatic probands with deficiencies of protein $\mathrm{C}(19 \%)$ or protein $\mathrm{S}(38 \%)$, indicating that the concomitant presence of more than one genetically determined thrombophilic condition confers a higher risk of venous thrombosis than single abnormalities (4-6). By contrast, an Italian study based upon the use of an APTT-based assay to diagnose APC resistance found no APC resistant case in symptomatic patients with protein $\mathrm{C}$, protein $\mathrm{S}$ or antithrombin deficiencies, nor in their asymptomatic relatives (7). Low incidence of thrombosis observed in the Italian families or different frequencies of the abnormal factor $\mathrm{V}$ allele in the Italian and Northern European populations (2) might account for the discrepant results.

We investigated 133 individuals belonging to 30 families with inherited deficiencies of antithrombin, protein $\mathrm{C}$ or protein $\mathrm{S}$ for the presence of the factor $\mathrm{V}$ mutation Arg506GIn, using the method of de Ronde et Bertina (8). Thirty-four individuals ( 16 of them were symptomatic) belonging to 10 families had antithrombin deficiency; 33 (16 symptomatic) belonging to 10 families had protein $\mathrm{C}$ deficiency; 28 (13 symptomatic) belonging to 10 families had protein $\mathrm{S}$ deficiency. The remaining 38 relatives had neither coagulation abnormalities nor previous thrombotic symptoms (Table 1). Heterozygosity for the mutant factor $V$ was found in $2 / 16(12.5 \%)$ symptomatic patients with antithrombin deficiency, in $2 / 13(14.3 \%)$ with protein $S$ deficiency, and in none of the 14 with protein $\mathrm{C}$ deficiency. The overall prevalence of the mutant factor $\mathrm{V}$ in the symptomatic deficienct subjects was $9.3 \%$ (95\% CI: 0.6-18). The mutant factor $\mathrm{V}$ was not found in the 52 asymptomatic deficient relatives nor in the 38 mon-deficient relatives. The difference

Table 1. Factor $V$ mutation in symptomatic patients with deficiencies of antithrombin protein C or protein $\mathrm{S}$, their asymptomatic family members with deficiencies, and their asymptomatic family members without deficiencies

\begin{tabular}{lccc}
\hline & \multicolumn{3}{c}{ No. with factor V mutation/No. tested } \\
\cline { 2 - 4 } type of defect & $\begin{array}{c}\text { symptomatic deficient } \\
\text { probands and relatives }\end{array}$ & $\begin{array}{c}\text { asymptomatic deficient } \\
\text { relatives }\end{array}$ & $\begin{array}{c}\text { asymptomatic } \\
\text { non-deficient relatives }\end{array}$ \\
\hline antithrombin & $2 / 16$ & $0 / 18$ & $0 / 6$ \\
protein C & $0 / 16$ & $0 / 19$ & $0 / 16$ \\
protein $\mathrm{S}$ & $2 / 13$ & $0 / 15$ & $0 / 16$ \\
Total & $4 / 43$ & $0 / 52$ & $0 / 38$ \\
\hline
\end{tabular}


between symptomatic and asymptomatic deficient individuals was statistically significant (Fisher's exact test, $\mathrm{p}=0.04$ ).

Prevalences of symptomatic individuals among the relatives with the defect were $25 \%$ (6/24) for antithrombin-, $17 \%$ (4/23) for protein $\mathrm{C}$ - and 17\% (3/18) for protein S-deficient relatives. These percentages are higher than those reported by Simioni and colleagues ( $8 \%$ for antithrombin, $6 \%$ for protein $\mathrm{C}$ and $14 \%$ for protein $\mathrm{S}$ ), but lower than those reported in the Northern European studies ( $31 \%$ for protein $C_{\text {, }} 19 \%$ to $67 \%$ for protein $S$ (4-6).

We conclude that in Italian families with the index cases affected by antithrombin, protein $\mathrm{C}$ or protein $\mathrm{S}$ deficiency the overall prevalence of the heterozygous state for factor $\mathrm{V}$ mutation is low $(3 \%)$. In our cohort factor $\mathrm{V}$ mutation was present only in symptomatic deficient subjects, confirming that the presence of combined coagulation abnormalities confers an increased thrombotic risk. The difference with the data of Simioni and colleagues could be explained by the higher prevalence of thrombosis in our cohort and by the fact that the DNA test used by us for the diagnosis of APC resistance may be more accurate than the APTT-based assay used by Simioni et al.

\section{REFERENCES}

1. Kalafatis $M$, Rand $\mathrm{MD}_{\mathrm{s}} \mathrm{Mam} \mathrm{KG}$. The mechanism of inactivation of human factor $\mathrm{V}$ and human factor $\mathrm{V}$ a by activated protein $\mathrm{C}$. Biol Chen 1994:269:3869-80

2. Rees DC, Cox M, Clegg JB. World distribution of tactor $V$ Leiden. Lancet 1995,346:1 133-4

3. Dalaback $B$. Intherited thombophifia: resistance to activated protein $C$ as a pathogenic factor of venons thrombocmbolism. Blood 1995:85:607-14

4. Koetemen BPC, Reitsma PH, Allatit CF, Bertina RM. Aciwated protein C resistance as an additional risk fâctor for thrombosis in protein $C$ deficient families. Blood 1994;84:10:31 *35

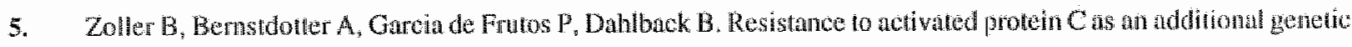
risk factor in hereditary deficiency of protein $S$. Blood 1995:85:3518-23

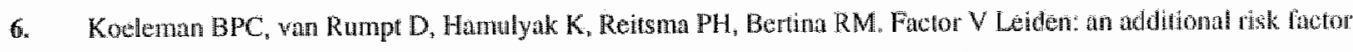
for thrombosis in protein $S$ deficient familes? Thromb Haemost 1995;74:580-3

7. Simioni P, Prandoni P, Grolami A. Patients with AT III, protein C or protein S defects stow no associnted hereditary APC-resistance. Thromb Hatrost $1994: 72: 481-2$

8. de Konde $H_{8}$ Bertina RM. Laboratory diagnosis of APC-resistance a dritical evaltwation of the test and the development of diagnostic criteria. Thuomb Haemost 1994:72:880 


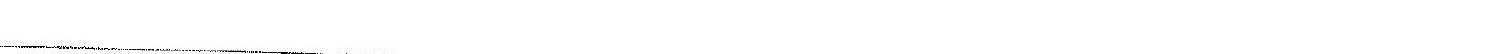




\section{Chapter 3}

\section{COAGULATION DEFECTS ASSOCIATED WITH INHERITED THROMBOPHILIA}

Resistance to activated protein $\mathrm{C}$ in unselected patients with arterial and venous thrombosis Am J Hematol 1997; 55: 59-64

Differential risks of thrombosis for four coagulation defects associated with inherited thrombophilia. A study of 150 families

Ann Intern Med, submitted. 


\title{
RESISTANCE TO ACTIVATED PROTEIN C IN UNSELECTED PATIENTS WITH ARTERIAL AND VENOUS THROMBOSIS
}

\author{
Elena Maria Faioni, Cristina Razzari, Ida Martinelli, \\ Daniela Panzeri, Franca Franchi, Pier Mannuccio Mannucci
}

"A. Bianchi Bonomi" Hemophilia and Thrombosis Center, Institute of Internal Medicine, IRCCS Ospedale Maggiore,

University of Milan, Italy

Am J Hematol 1997; 55:59-64 


\section{ABSTRACT}

Four hundred and ninety-three consecutive patients referred for arterial or venous thrombosis were screened for congenital and acquired abnormalities of blood congulation predisposing to thrombosis and were compared to 341 age- and sex-matched controls. The aim of the study was to determine the prevalence and clinical characteristics of resistance to activated protein C (APC), a defect shown to have different prevalences in different ethnic groups and to be associated with an increased risk of thrombosis. Seventy-three (15\%) patients had both APC resistance and the $1691 \mathrm{G}$ to A factor $\mathrm{V}$ gene mutation, compared to $6 / 341(2 \%)$ controls. Seven patients had antithrombin $(1.4 \%), 11$ protein $\mathrm{C}(2.2 \%)$, and 4 protein $\mathrm{S}(0.8 \%)$ deficiency. The relative risk of thrombosis in APC resistant patients was 9.4. Resistance to APC was associated mainly with venous thrombosis, the most frequent being deep vein thrombosis of the lower limbs. Fifty-eight percent of the APC-resistant patients had an associated risk factor at the first thrombotic event: pregnancy and oral contraceptive intake were associated with the first thrombotic episode in $35 \%$ and $30 \%$ of women respectively. APC resistance is the most frequent defect of blood coagulation in the general population and in the unselected thrombotic population studied by us.

\section{INTRODUCTION}

APC resistance is common in individuals of European ancestry and is the most frequent inherited defect associated with idiopathic venous thromboembolism (1). In the majority of cases $A P C$ resistance is the phenotypic manifestation of a point mutation ( $G 1691$ to $A$ ) in the gene of coagulation factor $V$ which predicts an amino acid substitution (Arg 506 to $\mathrm{Gln}$ ) in one of the cleavage sites for APC (2). The mutant factor $\mathrm{V}$ is clegraded more slowly by APC and this leads to less efficient inhibition of thrombin generation (3).

APC resistance can be diagnosed by functional assays that detect a shorter prolongation of clotting times induced by the addition of APC to plasma compared to normals (4). In addition, the genetic defect can be unravelled by DNA techniques (2). A very large variability in the prevalence of APC resistance has been observed both in patients with thrombosis (12-58 \%) (5-11) and in the general population $(0-15 \%)(2,6,8-10,12-14)$. The sensitivity and the specificity of the methods employed to diagnose APC resistance, the criteria used to select the patient populations and true ethnic variability all contribute to generate this wide range of prevalence values.

Few studies have analyzed in detail the clinical characteristics of thrombotic symptoms associated with APC resistance. The aim of our study was to analyze a large number of consecutive patients with arterial or venous thrombosis to determine the prevalence of APC resistance, the type of thrombotic symptoms associated with this defect, the risk 
factors associated with the first thrombotic event and the relative risk of thrombosis of APC-resistant patients compared with a control group taken from the general population.

\section{PATIENTS AND METHODS}

\section{Patients and Controls}

Five hundred and twenty-five consecutive patients with at least one objectively diagnosed episode of venous or arterial thrombosis were referred to the Thrombosis Center between January 1st 1993 and September 30th 1995. Of these, a total of $32(6 \%)$ patients were excluded from the stady due to the presence of a prolonged APTT or al condition that did not allow a reliable estimate of APC resistance with the functional method used for screening. Of the 32 excluded patients, 3 were pregnant, 6 had liver, renal or meoplastic disease, 6 had lupus anticoagulant and 17 other causes for a prolonged APTT. A total of 493 patients were included.

Deep vein thrombosis was diagnosed by ultrasonography or venography; pulmonary embolism, by ventilation-perfusion scan or angiography; superficial thrombophlebitis, by ultrasonography or clinical observation; cerebral vein or arterial thrombosis, by angiography, computerized tomography (CT) or magnetic resonance imaging (MRI); visceral vein thrombosis, by ultrasonography or CT scan; retinal vein thrombosis, by retinal fluorescein angiography. Acute myocardial infarction was diagnosed when an elevation of cardiac enzymes or specific alterations in the ECG or both were present; stroke by CT scan or MRI; a transient ischemic attack was diagnosed when focal neurological signs appeared ex novo and disappeared within 24 hours, whether or not alterations of CT or MRI were detected.

The personal and family history of all patients was collected, and for each thrombotic event the diagnostic procedure used, the type and site of thrombosis, the presence of associated risk factors and recurrences were documented. Pregnancy and the post-partum period, surgery, prolonged immobilization, trauma, oral contraceptive use, varicous veins (only for supeficial thrombophlebitis) and intravenous drug therapy (only for superficial thrombophlebitis) were considered risk factors for venous thrombotic events. Hypertension (systolic blood pressure $>160$ and/or diastolic blood pressure $>95 \mathrm{~mm} \mathrm{Hg}$, on at least two separate occasions), smoking (in excess of 10 cigarettes per day), dyslipidemia ( $>220 \mathrm{mg} / \mathrm{dl}$ blood cholesterol), overweight ( $\geq 20 \%$ excess over ideal body weight) and hyperglicemia ( $\geq 140 \mathrm{mg} / \mathrm{dl}$ fasting venous plasma glucose on at least two separate occasions) were considered risk factors for cardio- and cerebro-vascular events.

Three hundred and forty-one individuals recruited from the same geographical community of the patients were studied as a control group. They had a negative personal history of thrombosis as assessed by a validated questionnaire (15) and were chosen as 
they matched the patients for sex and age.

In patients and controls the following laboratory tests were performed (in patients at least three months after the thrombotic event); prothrombin time, activated partial thromboplastin time, fibrinogen, anticardiolipin antibodies, lupus anticoagulant, antithrombin, protein C, protein S and APC resistance (see below for methodology). When an abnormal result was found, the test was repeated after one month for confirmation and a family study was performed. When an abnormal result of the functional assay for APC resistance was confirmed, DNA analysis to detect the factor $V$ mutation was carried out.

\section{Methods}

APC resistance was measured using an APTT-based clotting assay slightly modified (7) from the original assay described by Dahlbäck et al (4). Specificity and sensitivity were 94 and $98 \%$, respectively. Results were expressed as normalized ratio (7). Search for the G1691 to A mutation in the factor $V$ gene was conducted by specific DNA amplification and digestion as described (16). Throughout this paper with the term "APC resistant" we refer to patients who have both APC resistance measured with the functional clotting test and the factor V G1691 to A mutation.

Antithrombin was measured by a commercially available functional assay (Coamatic Antithrombin, Chromogenix AB, Mölndal, Sweden) that evaluates its anti-Xa activity in the presence of heparin. In the presence of low values, the anti-thrombin activity (in the presence and absence of heparin) as well as the antigenic concentration were evaluated.

Protein $\mathrm{C}$ was measured by a functional clotting assay (IL Test ProClot, Instrumentation Laboratory S.p.A., Milano, Italy) after activation by a snake venom (Protac(B). In the presence of low values, the amidolytic activity and antigenic concentration were also measured.

Concentration of total and free protein $S$ were measured by ELISA with polyclonal anti-protein $\mathrm{S}$ antibodies (7). Free protein $\mathrm{S}$ was separated from that bound to $\mathrm{C} 4 \mathrm{~b}$-bind ing protein after precipitation of sample plasma with polyethylenglycol 6000 (3.5\% final concentration).

Anticardiolipin antibodies were measured by ELISA as described elsewhere (17).

\section{Statistical analysis}

Relative risk was determined as unadjusted odds ratio; $95 \%$ confidence intervals of prevalences and risk values were calculated by the normal approximation to the Poisson distribution (18). Statistical significance of the observed differences was determined by Fisher's test. 


\section{RESULTS}

\section{Characteristics of the consecutive patients}

Table 1 illustrates the type and prevalence of first thrombotic events that occurred in the 493 consecutive patients ( 303 women, 190 men, median age 39 years, range 1-75) included in this study. Median age at first event was 32 years (range 0-73), 31 years in women (range 0-66), 37 years in men (1-75). The most common event was deep vein thrombosis of the lower limbs $(38 \%)$, followed by ischemic stroke $(16 \%)$. On the whole, $34 \%$ of the referred patients had an arterial thrombotic event.

Table 1. Types of first thrombotic event in 493 consecutive patients with venous and arterial thrombosis referred to the Thrombosis Center over a 33 month time period

\begin{tabular}{lc}
\hline Type of event & $\mathrm{n}^{\circ}$ of palients (\%) \\
\hline Deep vein thrombosis & $188(38)$ \\
Stroke & $77(16)$ \\
Superficial thrombophlebitis & $72(15)$ \\
Transient ischemic attack & $55(11)$ \\
Myocardial infurction & $29(6)$ \\
Pulmonary enbolism & $24(6)$ \\
Cerebral vein thrombosis & $17(4)$ \\
Retinal vein thrombosis & $15(4)$ \\
Visceral thrombosis & $11(2)$ \\
Peripheral arterial thrombosis & $4(1)$ \\
Intracardiac thrombosis & $1(-)$ \\
\hline
\end{tabular}

* 2 renal infarctions, 1 Budd-Chiari syndrome, 4 splenic and/or portal thrombosis, 2 caval thrombosis, \& intestinal infarction and I multiple placental infarction

Associated risk factors at the first thrombotic episode were present in 301/493 $61 \%$, $95 \%$ C.I.: $54-68 \%$ ) of patients, and are shown in Table 2 . The two most common were oral contraceptive use ( $55 \%$ of women) and pregnancy and post-partum ( $19 \%$ of women).

\section{Prevalence of APC resistance and clinical characteristics of APC-resistant patients}

Seventy-three (median age 42 years, range $=19-71,41$ women, 32 men) of the 493 consecutive thrombotic patients had APC resistance according to our criteria $(15 \% ; 95 \%$ C. I.: $12-18 \%$ ). Seventy-one were heterozygous for the mutation, two homozygous. Median age at the first thrombotic episode in APC-resistant patients was 29 years (range= 16-56). The type and site of the first thrombotic event is shown in Table 3. The most frequent events were deep vein thrombosis of the lower limbs and superficial thrombophlebitis. Arterial thrombotic events represented only $12 \%$ of total. Fifty-eight percent of 
Table 2. Risk factors associated with the first thrombotic event in 493 consecutive patients with venous and arterial thrombosis refe-red to the Thrombosis Center over a 33 month fime period

\begin{tabular}{lc}
\hline Risk factor & $\mathrm{n}^{\circ}$ of patients $(\%)$ \\
\hline Oral contraceptiwes & $111(55) *$ \\
Pregnancy and post-partum & $39(19)$ \\
Smoking & $38(13)$ \\
Surgery & $33(11)$ \\
Tranma and immobilization & $31(10)$ \\
Dyslipidemiatsmokingthypertension & $20(7)$ \\
Varicous veins & $10(3)$ \\
Intravenous drug therapy & $7(2)$ \\
Hypertension & $7(2)$ \\
Diabetes $\$$ & $3(1)$ \\
Dyslipidenia & $1(<1)$ \\
Overweight & $1(<1)$ \\
\hline
\end{tabular}

Percent is calculated on the total number of women having an associated risk factor.

$\$ 2$ type I and I type 11 diabetes mellitus.

Table 3. Types of first thrombotic event in 73 APC-resistant patients

\begin{tabular}{lc}
\hline Type of event & $n^{\circ}$ of patients (\%) \\
\hline Deep vein thrombosis of the lower limbs & $42(58)$ \\
Superficial thrombophlebitis & $17(23)$ \\
Stroke & $4(5)$ \\
Cerebral vein thrombosis & $3(4)$ \\
Transient ischemic attacks & $3(4)$ \\
Myocardial infarction & $2(3)$ \\
Pulmonary embolism & $1(1)$ \\
Visceral vein thrombosis & $1(1)$ \\
\hline
\end{tabular}

patients (42/73) had an associated risk factor at the first thrombotic event. The most frequent factors (Table 4 ) were pregnancy and post-partum (35\% of women), followed by oral contraceptive use ( $32 \%$ of women) and trauma ( $13 \%)$.

\section{Prevalence of other defects and associations with APC resistance}

Seven of the $493(1.4 \%, 95 \%$ C.I.: $0.6-3 \%), 11 / 493(2.2 \%, 95 \%$ C.I. $1-4 \%)$ and $4 / 493(0.8 \%$, 95\% C.I.: 0.2-2\%) consecutive patients had a deficiency of antithrombin, protein Cand protein $S$ respectively. None of the 493 patients were positive for anticardiolipin antibodies (defined as the presence of anti-cardiolipin IgG > 10 units, confirmed once after at least eight weeks) (17). One of the antithrombin deficient patients was also APC-resistant. For this patient (a 30 year 
Table 4. Risk factors associated with first thrombotic event in 73 APC-resistant patients

\begin{tabular}{lc}
\hline Risk factor & n $^{0}$ of patients $(\%)$ \\
\hline Pregnancy and postpartum & $13(35)^{*}$ \\
Oral contraceptives & $12(32)^{*}$ \\
Traumat & $6(13)$ \\
Varicose veins & $4(9)$ \\
Surgery & $3(7)$ \\
Smoking & $3(7)$ \\
Prolonged immobilization & $2(4)$ \\
Hypertension & $1(2)$ \\
Intravenous drug therapy & $1(2)$ \\
\hline
\end{tabular}

* Percent is calculated on the totall number of women having as associated risk factor

old woman) a family study was not feasible. Her thrombotic symptoms were severe, i.e. cerebral vein thrombosis at the age of 29 while she was on oral contraceptives for three months and, at the same time, deep vein thrombosis of a lower limb, complicated by pulmonary embolism.

\section{Relative risk of thrombosis in APC-resistant patients}

To determine the relative risk of thrombosis in APC-resistant patients compared to non resistant individuals, 341 sex-and age-matched controls were chosen from the general population. Six of 341 controls were resistant to APC and were heterozygous for the G1691 to A mutation with a prevalence of $2 \%(95 \%$ C.I.: $1-4 \%)$. The relative risk of thrombosis for heterozygotes, calculated as unadjusted odds ratio, was 9.4 (95\% C.I. $4.1-22.0, p<0.0001)$.

\section{Prevalence of APC resistance in patients with early-onset venous thrombosis}

The 493 patients included in our study were not selected for age of onset nor for the type of the first thrombotic event. Since these features of the cohort may have contributed to the relatively low prevalence of $A P C$ resistance found, we selected a subgroup of consecutive patients who had early-onset venous thromboembolism, i.e. a first venous thrombotic event before age 45. Patients fullfilling these criteria were 256 (178 women, 78 men, median age 35 years, range 1-71). The main thrombotic events in these patients were deep vein thrombosis of the lower limbs $(61 \%)$ and superficial thrombophlebitis (21\%). Median age at the onset of the first thrombotic episode was 28 years (range 1-44). Prevalence of APC resistance in this selected subgroup was $20 \%(51 / 256,95 \%$ C.I.: $15-26 \%$ ). 


\section{DISCUSSION}

We chose to analyze a large unselected population with arterial and venous thrombosis to determine the prevalence of APC resistance and to characterize, without preselection, the type of thrombotic episodes associated with APC resistance. A relatively small number of consecutive patients was excluded from the study due to the presence of a prolonged APTT or a condition (such as pregnancy or lupus anticoagulant) that did not allow a reliable estimate of APC resistance with the functional assay used for screening.

The Thrombosis Center of our hospital is a tertiary referral center which receives patients mainly from Northern Italy, though referrals from Central and Southern Ituly are not uncommon. Patients are generally referred by their family physician or from district hospitals. In our cohort, the median age at the first event was relatively young, but the wide range indicates that older patients are also referred. There were more women than men, and this may in part explain why the most relevant risk factors associated with the first event were oral contraceptive use, pregnancy and post-partum. As anticipated, the most frequent defect found in our series was APC resistance. Among 73 patients with this defect, the most frequent thrombotic events were deep vein thrombosis of the lower limbs and superficial thrombophlebitis. Cerebral vein thrombosis, which has recently been shown to be associated with APC resistance (19), was found in $4 \%$ of patients. Onset of thrombosis occurred at a young age, the range being narrower (range 16-56 years) than for the 493 consecutive patients (range $0-73$ years).

Only $12 \%$ of total events in APC-resistant patients were arterial, compared to the $34 \%$ of the consecutive patients. It is still debated whether resistance to APC is associated with arterial thrombosis. The majority of clinical studies $(1,9,10,14)$, one of which prospective (10), indicate that APC resistance is not associated with myocardial infarction or cerebrovascular disease, though a recent report shows a relatively high prevalence of the factor $\mathrm{V}$ mutation in young women who smoke and have myocardial infarction (20). In our Center, a retrospective study of patients with juvenile stroke suggests that only cryptogenetic stroke may be associated with a higher prevalence of the factor $V$ mutation (21). The association of APC resistance with peripheral arterial occlusion thas not been extensively evaluated.

Age of onset and distribution of symptoms in APC-resistant patients were very similar to those observed in the congenital defects of protein $C$ and protein $S$ (22). Independent risk factors most frequently associated with the first thrombotic episode were pregnancy, post-partum and oral contraceptive use. Pregnancy and post-partum are associated with a high prevalence of thrombosis also in women deficient in antithrombin, protein $\mathrm{C}$ and protein S $(23,24)$. More than half of APC resistant women appear to experience the first thrombotic event during pregnancy (25-27). Hence, the usefulness of screening for the factor $V$ mutation in pregnant women should perhaps be evaluated. The association of 
oral contraceptive use with APC resistance confers a relative risk for thrombosis of approximately 34 compared to non resistant women who do not use oral contraceptives (28). This impressive figure and the frequent finding of oral contraceptive use as an independent risk factor associated with the first thrombotic episode in APC resistance $(1,9,12,28)$, confirmed also in our series, poses the question of the usefulness of screening for APC resistance before starting oral contraceptives. A recent report suggests that screening for APC resistance before starting oral contraceptives might not be cost-effective (29). This report deals only with fatal thrombotic events. An evaluation of cost-effectiveness should be also carried out considering non-fatal thrombotic events, which are more frequent, and taking into account the peculliar epidemiological, social and publichealth aspects of each country.

The $15 \%$ prevalence of APC resistance found in this study is at the lower end of the range of values reported in the literature $(12-58 \%)$. This is likely to be due both to the relatively low prevalence of APC resistance in Italy (2\% in our control group) and to the fact our cohort was not selected for age or type of thrombotic event. On the other hand, when patients were selected for the type of thrombosis (only venous) and for age of onset (less than 45 years old) the prevalence of APC resistance was $20 \%$. This confirms that APC resistance is a risk factor for venous thrombosis in the young. It has been shown that APC resistance is a risk factor also for older patients (10,30). Accordingly, we found 22/237 (9\%) APC-resistant patients with a first event after 45 years of age.

From our study, APC-resistant patients have a relative risk of developing thrombosis which is approximately nine times that of non resistant individuals, a figure consistent with those reported by other groups for heterozyotes $(2,6,9)$. Homozygotes were excluded from this calculation, but due to their low number, no separate evaluation of risk was possible.

We found only one resistant patient with an associated deficiency of a naturally occurring anticoagulant, namely antithrombin. Because a family study was not possible, we could not study segregation patterns and development of symptoms in patients with dual deficiencies. However, this patient had a very severe thrombotic history, in agreement to what has been reported in the literature for patients with dual deficiencies (31-33).

In conclusion, APC resistance associated with factor V G1691 to A mutation is frequent in the general population and in unselected patients with thrombosis in Italy. APC resistance conveys a nine-fold higher risk of developing thrombosis than that of individuals without the mutation. Symptoms are similar to those observed in hereditary thrombophilic syndromes due to deficiencies of the protein $C$ pathway. Since the most frequent risk factors associated with the first thrombotic event are oral contraceptive use and pregnancy and post-partum, evaluation of cost-effectiveness of screening for APC resistance in women is suggested. 


\section{REFERENCES}

1. Danlbek B. New molecular insights into the genetics of thrombophilia. Resistance to nctivated protein $\mathrm{C}$ crussed by Arg 506 to Gln mutation in factor $V$ as a pathogenic risk factor for venous thrombosis. Thromb Hatemost 74 $139-148,1995$.

2. Bertina RM, Koeleman BPC, Koster T, Rosendaal FR, Dirven RI, de Ronde H, van der Velden PA, Reitsma PH. Mutation in blood coagulation factor $V$ associated with resistance to activated protein $C$. Narure 369:64-67, 1994.

3. Kalafatis M. Bertina RM, Rand MD. Mam KG. Characterization of the molectlar defeot in factor V R 506 . J Biot: Chem 270: 4053-4056, 1995

4. Dahlbck $B$, Carlsson $M$, Svensson PJ. Familial thrombophilia due to a previously unecognized mechanism caracterized by poor anticangulant response to activated protein $C$ : prediction of a coffactor to activated protein $C$. Proc Natl Acad Sei U.S.A. 90: 1004-1008, 1993.

5. Griffin JH, Evatt B, Wideman $\mathrm{C}$, Fernandez JA. Anticongulant protein $\mathrm{C}$ pathway defective in majorily of thrombophilic patients. Blood 82: 1989-1993, 1993.

6. Koster $T$, Rosendaal FR, de Ronde H, Bri't E, Vandenbroucke JP, Bertina RM. Venous thrombosis dua to poor anticoagulant response to activated protein $C$ : Leiden Thrombophilia study. Latancet 342: 1503-1506, 1993.

7. Faioni EM, Franchi F, Ast D, Sacchi E, Bernardi F, Mannuce PM. Resistance to activated protein C in nine thrombophilic families: interference in a protein $S$ functional assay. Thromb Hitemost 70: 1067-1071, 1993.

8. Halbmayer W-M, Haushofer A, Schn R, Fisher M. The prevalence of poor anticoagulant response to aclivated protein C (APC resistance) among patients suffering from stroke or venous thrombosis and among heal thy subjexts. Blood Coag Fibrinol 5: 51-57, 1994.

9. Swensson PJ, Dalltbek B. Resistance to activated protein $\mathrm{C}$ as a basis for venous thrombosis. $\mathrm{N}$ Engl I Mad 300 : $517-522,1994$.

10. Ridker PM, Hennekens $\mathrm{CH}_{8}$ Lindpaintner $\mathrm{K}$, Stampfer MJ, Eisenberg PR, Miletich JT: Mulation in the gene coding for coagulation factor $\mathrm{V}$ and the risk of myocardial infarction, stroke and wenous thrombosis in apparently heilliny men. N Engl J Med 332:912-917, 1995.

11. Leroy-Matheron C, Levent M, Pignon J-M, Mendona C, Gouault-Heilmann M. The 1691 GA muttion in the factor $\checkmark$ gene: relationship to activated protein $\mathrm{C}$ (APC) resistance and thrombosis in 65 patients. Thromb Hatemos 75 : 4.10. 1996.

12. Beauchamp NJ, Daly ME, Hampton KK, Cooper PC, Preston EF, Pealke IR. High prevalence of a mutation in the factor $\mathrm{V}$ gene within the U.K. poptlation: relationship to actiwated protein $\mathrm{C}$ resistance and familith thrombosis, B. I Haemstoll 88: $219-222,1994$.

13. Rees DC, Cox M, Clegg JB. World disiribution of factor V Leiden. Lancet 346: 1133 +1134, 1995.

14. Emmerich J, Poirier O, Evans A, Margues-Vidal P, Arveiler D, Lue G, Aiach M, Cumbicn F. Myocardial infurelion, Arg506 to Gln factor $V$ mutation, and actiwated protein $C$ resistance. Lance 345: 321-322, 1995.

15. Frezzato M, Tosetto A, Rodeghiero F. Validation of a questionaure for the diagnosis of venous thrombounbolism. BrJ Haematol 87: 79, 1994.

16. de Ronde H. Bertina RM. Laboratory diagnosis of APC resistance: a critical evaluation of the test and the development of diagnostic criteria. Thromb Haemost 72: 880-886, 1994.

17. Triplett DA. Antiphospholipid-protein antibodies: laboratory detection and clinical relevance. Thromit Res $78: 1-31$, 1995.

18. Hirsch RP, Riegelman RK. Statistical first aid. Interpretation of health research data. Blackwell Scientific Publications, Boston, U.S.A. 1992.

19. Martinelli I, Landi G, Merati G, Cella R, Toseto A, Mannucei PM. Factor V gene mutation is a risk factor lor cerebral venous thrombosis. Thromb Haenost 75: 393-394, 1996. 
20. Rosendwal FR, Siscowiek DS, Schwartz SM, Reitsma PH. Increased risk of myocardial infarction associaled with factor V Leiden (APC-resistance) among young women. Blood 86 (Suppl. 1): 615a, 1995.

21. Landi $O$. Cella E, Martineli I. Tagliabue L, Mannuce PM, Zerbi D. Arg506Gin and cerebral ischemia in the young. Stroke 27: $1697-8,1996$

22. De Stetano $V$, Finzza $G$, Mannuct PM. Inherited thrombophilia pathogenesis, clinical syndromes and management. Blood 87: 353144,1996

23. Conard I, Horellou MH, Van Dreden $P$, Lecompte T, Samama M. Thrombosis and pregnancy in congenital deficiencies of AT II, protein C or protein S: study of 78 women. Thromb Haemost 63: 319-320, 1990.

24. De stefuno B, Leone G, Mastrangelo $S$, Tripodi A, Rodeghiero F, Castaman $G$, Barbui T, Finazzi G, Bizzi B, Manintei PM. Thrombosis during pregnancy and surgery in patients with congenital deficiency of antithrombin III, protein C, protein S. Thromb Hemost 71: 799-800, 1994.

25. De Stefano V, Masfrangello S. Paciaroni K, Ireland H, Lane DA. Thrombotic risk duning pregnancy and puerperium in women with APC-reststance: effective subcutaneous heparin prophylax is in an pregnant patient. Thatomb Haemost 74: 793-794, 1995.

26. Conard 4, Trossaer M, Horellou MH, Elalamy I, Chelouft L, Samama M M. Risk of venous thronbosis in 51 women with resistance to activated protein $\mathrm{C}$ associated with factor $\mathrm{V}$ Leiden. Thromb Haemost 73: 1375, 1995. (Abstriact).

27. Helgren $M$, Svensson $P J$, Dahlbek B. Resistance to activated protein $C$ as a basis for venous thromboembolism associnted with pregnancy and oral contraceptives. An J Obs Gyn 173: 210-213, 1995.

28. Vandeabroucke JP, Kaster T, Bri't E, Reitsma PH, Bertina RM, Rosendaal FR. Increased risk of wenous thrombosis in oral contraceptive users who are carriers of factor $V$ Leiden mutation. Lancet 344: 1453 1457, 1994.

29. Rosendand FR. Oral contraceptives and screening for factor V Leiden. Thromb Haemost 75: 524-525, 1996.

30. Rosendaal FR, Koster $T$, Vandenbrotcke JP, Reitsma PH. High risk of thrombosis in patients homozygous for factor V'Leiden (activated protein C resistance). Blood 85: 1504-1508, 1995.

31. Koeleman BPC, Reissma PH, Allaart CF, Bertina RM. Activated protein C resistance as an additional risk fanctor for thrombosis in protein C-deficient fumilies. Blood 84: $1031-1035,1994$.

32. Zller B, Berntsdotter A, Garcia de Frutos P, Dahlbck B. Resistance to activated protein C as an additional genetic risk factor in hereditary deficiency of protein S. Blood 85: 3518-3523, 1995.

33. van Boven HH, Reitsma PH, Rosendaal FR, Bayston TA, Chowdhury V, Bauer KA, scharrer I, Conard J, Lane DA. Foctor $V$ Leiden (FV R506Q) in families with inherited antithrombin deficiency. Thromb Haemost 75 : $417-421,1996$ 


\title{
DIFFERENT AL RISKS OF THROMBOSIS FOR FOUR COAGULATION DEFECTS ASSOCIATED WITH INHERITED THROMBOPHILIA
}

\author{
A Study of 150 families
}

Ida Martinelli, Pier Mannuccio Mannucci, Valerio De Stefano*, Emanuela Taioli, Valentina Rossi, Francesca Crosti, Katia Paciaroni*, Giuseppe Leone*, Elena M.Faioni

"A. Bianchi Bonomi" Hemophilia and Thrombosis Center and Epidemiology Unit, Institute of Internal Medicine, IRCCS Ospedale Maggiore, University of Milan, and *Department of Hematology, Catholic University, Rome, Italy

Ann Intern Med, submitted

Grant support: this study was supported by a grant from Istituto Superiore di Sanitù (Progetto Sangue), by institutional grants of the IRCCS Maggiore Hospital and by a grant from Rolo Banca $1473 \mathrm{Spa}$ 


\section{ABSTRACT}

Background: Deficiencies of the naturally-occurring anticoagulant proteins, such as antithrombin, protein $C$ and protein $S$ and activated protein $C$ resistance are associated with inherited thrombophilia. So far, no direct comparison of the thrombotic risk associated with these genetic defects is available.

Objective: To compare the lifetime probability of developing thrombosis, the type of thrombotic symptoms and the role of circumstantial triggering factors in individuals with different thrombophilic defects.

Design: Retrospective cohort family study.

Setting: Two referral Thrombosis Centers, University of Milan and Rome, Italy.

Study group: 723 first- and second-degree relatives of 150 index patients with antithrombin, protein $\mathrm{C}$, protein $\mathrm{S}$ deficiency or activated protein $\mathrm{C}$ resistance.

Measurements: Antithrombin, protein $C$ and protein $S$ were measured by functional and antigenic assays. Activated protein $\mathrm{C}$ resistance was diagnosed by DNA analysis for the Arg506Gln mutation in the coagulation factor $\mathrm{V}$ gene.

Results: We found higher risks for thrombosis for subjects with antithrombin (risk ratio $8.1,95 \%$ confidence interval, 3.4 to 19.6$)$, protein $\mathrm{C}(7.3,95 \%$ confidence interval, 2.9 to 18.4$)$ or protein $S$ deficiency $(8.5,95 \%$ confidence interval, 3.5 to 20.8$)$ and activated protein $\mathrm{C}$ resistance $(2.2,95 \%$ confidence interval, 1.1 to 4.7$)$ than for individuals with normal coagulation. The risk of thrombosis for those with activated protein $\mathrm{C}$ resistance appeared to be lower than that for those with the other coagulation defects combined $(0.3,95 \%$ confidence interval, 0.1 to 1.6), even when arterial and superficial vein thromboses were excluded and the analysis was restricted to deep vein thrombosis $(0.3,95 \%$ confidence interval, 0.2 to 0.5$)$. No association between thrombophilic defects and arterial thrombosis was found. The most frequent venous thrombotic manifestation was deep vein thrombosis, with or without pulmonary embolism, $90 \%$ in antithrombin, $88 \%$ in protein $\mathrm{C}, 100 \%$ in protein $\mathrm{S}$ deficiency, and $57 \%$ in activated protein $\mathrm{C}$ resistance), but a relatively mild manifestation such as superficial vein thrombosis was common in activated protein $\mathrm{C}$ resistance $(43 \%)$. There was a predisposing factor at the time of venous thromboembolism in approximately $50 \%$ of cases for each of the four defects.

Conclusions: Activated protein $\mathrm{C}$ resistance is associated with a relatively small risk of thrombosis, lower than that for antithrombin, protein $\mathrm{C}$ or protein $\mathrm{S}$ deficiency. In addition, activated protein C-resistant individuals develop less severe thrombotic manifestations, such as superficial vein thrombosis. 


\section{INTRODUCTION}

Inherited thrombophilia is a genetically determined tendency to venous thromboembolism that develops in young patients (less than 45 years) and tends to be recurrent. The most frequent of the inherited defects of the coagulation mechanisms that cause a thrombophilic state is resistance to activated protein C (1). Caused by an Arg506Gin mutation on human factor $\mathrm{V}$, this abnormality is present in approximately 50 percent of the patients who develop venous thromboembolism at a young age and has a high frequency in the populations of European ancestry (2-4). Deficiencies of the naturally. occurring anticoagulant proteins antithrombin, protein $\mathrm{C}$ and protein $\mathrm{S}$ account altogether for 5 to 10 percent of cases $(5,6)$. The risk of thrombosis associated with each of these coagulation defects has been investigated in family studies (2,7-10) or case-control studies (11-14) that revealed an increased thrombotic risk in carriers of the defect compared with non-carriers.

So far, only one family study has compared deficiencies of the naturally-occurring anticoagulant proteins with the lifelong probabilities of affected individuals developing thrombosis (15), but the most common defect, activated protein $C$ resistance, was not considered. Since knowledge about differences in the thrombotic risk might have implications in treatment strategies, we have carried out a retrospective cohort family study of 723 affected and unaffected relatives of 150 index patients with inherited deficiencies of antithrombin, protein $C$ or protein $S$ or with activated protein $C$ resistance. Secondary goals of the study were to compare the types of thrombotic manifestations, and to evaluate the roles of other factors predisposing to venous thromboembolism (such as surgery, trauma and immobilization, pregnancy or puerperium and oral contraceptive intake) in triggering such events.

\section{PATIENTS AND METHODS}

\section{Patient selection criteria}

Families were identified through index patients (probands) who attended two Italian Thrombosis Centers in Milan and Rome, specializing in the management of coagulation disorders between 1980 and 1995. The selection criteria for inclusion of families in the study were the presence of an inherited coagulation defect predisposing to thrombosis (antithrombin, protein $\mathrm{C}$ or protein $\mathrm{S}$ deficiency or activated protein $\mathrm{C}$ resistance) in at least two family members and the availability of laboratory results for the diagnosis of the four defects in each family member. Index patients were asked to bring to the two Centers as many as possible first- and second degree rellatives.

Their personal and family histories of thrombosis were collected with a validated 
structured questionnaire (16). None of them had any evidence of overt neoplastic or other systemic diseases. The date of occurrence and the site of any episode of venous or arterial thrombosis, the presence of other factors predisposing to venous thromboembolism in the month preceding the event (such as surgery, trauma, prolonged immobilization, pregnancy or puerperium, or oral contraceptive intake) were collected. A surgical procedure was defined as one in which general anesthesia was performed; trauma included bone fractures or the application of casts, excluding those of the upper extremity; a period of prolonged immobilization was defined as one in which bed rest was complete for at least two weeks.

Symptomatic patients, i.e., those who reported having had thrombosis in the past, were asked to bring with them the diagnostic documentation of thrombotic events and a copy of clinical records. The term venous thromboembolism was used for deep vein thrombosis whether or not complicated by pulmonary embolism; the term deep vein thrombosis for venous thrombotic episodes affecting the extremities, the portal-mesenteric circulation or the cerebral circulation. The diagnosis of superficial vein thrombosis was based on the description of typical signs and symptoms, and in some cases it was confirmed by Doppler ultrasound. Other thrombotic events had to be confirmed by objective methods: venography or compression ultrasonography for deep vein thrombosis; (ventilation)/perfusion lung-scan for pulmonary embolism; electrocardiography, abnormal myocardial enzymes and chest pain for myocardial infarction; computed tomography or magnetic resonance imaging for ischemic strokes. The diagnosis was transient ischemic attacks when focal neurological signs appeared de novo and disappeared within 24 hours, whether or not abnormalities in computed tomography or magnetic resonance imaging were detected. Five patients who reported previous episodes of deep vein thrombosis of the lower extremities but were unable to provide objective documentation were included in the study because they had been on anticoagulant treatment and/or because a Doppler ultrasound performed at the time of our visit revealed reflux in the deep veins indicative of a postphlebitic syndrome.

\section{Laboratory tests}

Antithrombin heparin cofactor activity was measured by an amidolytic assay (Coamate AT, Chromogenix AB, Mölndal, Sweden); when antithrombin levels were low, the defect was further characterized by measuring antigen levels (immunoelectrophoresis, polyclonal antibody, Stago, Asnieres, France) and functional activity in the absence of heparin and by performing crossed immunoelectrophoresis with or without heparin (17). Protein $\mathrm{C}$ activity was assayed in Milan by a clotting assay (ProClot, Instrumentation Laboratory, Milan, Italy) and in Rome by an amidolytic assay (Coamatic Protein C, 
Chromogenix) after activation with a snake venom (Protac(B). When plasma levels of protein Cactivity were low, antigen levels were also measured by ELISA using polyclonal antibodies (Dako A/S, Glostrup, Denmark). Total protein $S$ antigen was measured by ELISA using polyclonal antibodies (Dako A/S, Glostrup, Denmark); free protein $\mathrm{S}$ was measured in the same way after precipitation of the C4b-binding protein-protein $S$ complex with polyethyleneglycol 6000 (3.5\% final concentration) (18) or directly by ELISA using a commercial kit using a specific monoclonal antibody (Asserachrom Free Protein S, Stago). The Arg506GIn mutation in the factor $\mathrm{V}$ gene was searched for by specific DNA amplification and digestion, as published (19).

\section{Statistical analysis}

The $t$-test was used to compare mean age values; the Cochran-Cox approximation for unequal variances was used when the variable was not normally distributed. The Chisquare test was used to compare the prevalence of thrombotic manifestations. The thrombosis-free survival was estimated from birth to the age of the first thrombotic event by Kaplan-Meier method curves and the different thrombophilic defects were compared by the Wilcoxon test, which places more weight on early events, and the log-rank test, which places more weight on later events. Conditional risk ratios and $95 \%$ confidence intervals (CI) for the different defects were calculated with the PHREG procedure of the SAS package (20), which adjusts for other variables in the model.

Each family was assigned a code number, that represents the genetic defect present in the proband which was used to identify the family. This code was called "family status". In addition, all the family members of the same family were assigned code numbers, defined as "familiality". Variables included in the multivariate model were sex, family status, and familiality, in order to control for the defect of the index patient and for shared environmental and genetic factors within families.

Our funding sources had no role in the collection, analysis or interpretation of data.

\section{RESULTS}

\section{Characteristics of index patients}

The index patients were 180 unrelated individuals who, after a first thrombotic episode had been referred consecutively to the Thrombosis Centers and diagnosed as having a coagulation defect. Thirty index patients were excluded because no relatives were available for study. Among the remaining 150 index patients venous thromboembolism was the most frequent symptom (76\% of cases), followed by superficial vein thrombosis (15\%) and arterial thrombosis $(7 \%)$. Twenty-five patients $(17 \%)$ had antithrombin 
deficiency (19 type I and 5 type $I I, 2$ of them with a heparin-binding site defect), 23(15\%) had protein $C$ deficiency (22 type I and 1 type $M$ ), 15 (10\%) had protein S deficiency (14 type $I$ and 1 type II) and 81 (54\%) had activated protein C resistance. Six (4\%) had double defects: two activated protein $\mathrm{C}$ resistance and antithrombin deficiency (type I), two activated protein $\mathrm{C}$ resistance and protein $\mathrm{S}$, one activated protein $\mathrm{C}$ resistance and protein $C$ deficiency (type I), and one protein C (type I) and protein S deficiency. Six index patients with activated protein $\mathrm{C}$ resistance and two with protein $\mathrm{C}$ deficiency were homozygotes.

\section{Characteristics of relatives}

The entire cohort of first- and second-degree relatives of the 150 index patients consisted of 1213 individuals, some dead some alive at the time of the study. From 723 relatives blood was taken for coagulation testing and they represent the actual study group. The average number of relatives per family was 8.1 (range 1-12) considering the entire cohort and 4.8 (range 1-20) considering the study group. For 569 of the 723 relatives medical histories were obtained directly during a personal interview, using the same questionnaire administered to the index patients, while for the remaining 154 relatives it was obtained by interviewing the index patients. Laboratory tests became available after the medical history was obtained and the laboratory staff were unaware of the clinical data. The coagulation status for 490 of the entire cohort of 1213 relatives could not be investigated because they had died or refused to attend the Thrombosis Centers. However, for 411 of them both demographic data (sex and age) and information about the medical history could be obtained from the index patients. In these relatives, the prevalence of thrombosis (20\%) and sex and age distribution were similar to those of the relatives who could be investigated $(16 \%$, see below). For the remaining 79 relatives not investigated, only demographic information could be obtained.

Table 1 shows the main characteristics of the study group, which did not differ for relatives recruited in Milan or Rome.

Table 1 "Chatacteristics of the study populaton of firs-and-second-deggee reintives screened for congutation defocts

\begin{tabular}{|c|c|c|c|c|c|c|c|}
\hline \multirow[b]{3}{*}{ relatives, No. } & \multicolumn{7}{|c|}{ coagtilltion defect } \\
\hline & total & $\begin{array}{c}\text { no } \\
\text { deftect }\end{array}$ & $\begin{array}{l}\text { antithronbin } \\
\text { deficiency }\end{array}$ & $\begin{array}{l}\text { protein } C \\
\text { deficiancy }\end{array}$ & $\begin{array}{l}\text { protein } 5 \\
\text { defteiency }\end{array}$ & $\begin{array}{c}\text { APC } \\
\text { resistince }\end{array}$ & $\begin{array}{l}\text { double } \\
\text { atceters }\end{array}$ \\
\hline & 723 & $32 \%(45 \%)$ & $8,5(129)$ & $64(90)$ & $40(6 \%)$ & $200 / 28 \%$ & $6(1 \%)$ \\
\hline men/nomis & $323 / 991$ & 152175 & $45 / 40$ & $35 / 29$ & $18 / 2\}$ & 77123 & $5 / 1$ \\
\hline $\begin{array}{l}\text { nge (yeturs) } \\
\text { moan } \pm \mathrm{SD}\end{array}$ & $40+19$ & $38 \pm 18$ & $40 \pm 20$ & $40+21$ & $44 \pm 20$ & $42+20$ & $45+23$ \\
\hline and ratuggin & 1.94 & $1 . .90$ & $2-84$ & $1.9 \|$ & $6-79$ & 6094 & $6-68$ \\
\hline
\end{tabular}


The vast majority of relatives had the same defect as the index patient of the family to whom they belonged. There were 3 relatives with protein $S$ deficiency who had an index patient with activated protein $\mathrm{C}$ resistance and one with activated protein $\mathrm{C}$ resistance who had an index patient with antithrombin deficiency. Three-hundred and twenty-seven relatives had no coagulation defects, 396 relatives carried at least one defect. Of these, 85 had antithrombin deficiency (62 type $I$ and 23 type II, 10 of them with heparin-binding site defect), 64 protein $C$ deficiency ( 62 type $I$ and 2 type II), 41 protein $S$ deficiency ( 40 type $I$ and 1 type $\mathbb{I I}$ ), 200 had activated protein $C$ resistance and 6 had double defects ( 2 protein $C$ and protein $S$ deficiencies, 2 protein $C$ and antithrombin deficiencies, 1 activated protein $C$ resistance and antithrombin deficiency, 1 activated protein $\mathrm{C}$ resistance and protein $\mathrm{C}$ deficiency). Homozygosity for activated protein $\mathrm{C}$ resistance was detected in 6 of 200 relatives with this defect.

\section{Type and age at development of thrombotic events}

One-hundred and sixteen $(16 \%)$ of the 723 relatives had had at least one thrombotic episode $(35 \%$ with antithrombin deficiency, $30 \%$ with protein $\mathrm{C}, 37 \%$ with protein $\mathrm{S}$, $18 \%$ with activated protein $\mathrm{C}$ resistance, $5 \%$ in those with no defect and $33 \%$ in those with double defect) (Table 2).

The types of the first thrombotic event for the relatives with different congulation defects are also shown in Table 2.

Venous thromboembolism was the most frequent thrombotic manifestation. The sites of deep vein thrombosis were the lower extremities in all except three cases (one with antithrombin deficiency had portal-mesenteric vein thrombosis, one with protein $\mathrm{S}$ deficiency had cerebral vein thrombosis, and one with activated protein C resistance had upper extremity deep vein thrombosis). Deep vein thrombosis was accompanied by pulmonary embolism in $11 \%$ of the cases (three with antithrombin, one with protein $\mathrm{C}$, one with protein $S$ deficiency, two with activated protein $C$ resistance, and one with no defect). Superficial vein thrombosis accounted for $10 \%$ of the thrombotic episodes in subjects with antithrombin deficiency, for $13 \%$ in those with protein $\mathrm{C}$ deficiency, but was not seen in protein $S$ deficiency. The prevalence of venous thromboembolism in activated protein $\mathrm{C}$ resistance $(57 \%)$ was lower than in antithrombin $(90 \%, \mathrm{p}=0.007)$, protein $\mathrm{C}(88 \%, \mathrm{p}=0.05)$ or protein $\mathrm{S}$ deficiency $(100 \%, \mathrm{p}=0.008)$, while that of superficial vein thrombosis was higher $(43 \%$ compared to $10 \%, \mathrm{p}=0.03 ; 13 \%, \mathrm{p}=0.05$ and zero $\%$, $\mathrm{p}=0.02$ ). Arterial thrombosis accounted for 3,5 and $7 \%$ of thrombotic episodes in activated protein $\mathrm{C}$ resistance, protein $\mathrm{C}$ or protein $\mathrm{S}$ deficiency, did not occur in antithrombin deficiency and was present in $2 \%$ of relatives with no defects $(p=0.9,0.8$ and 0.8 respectively). Two protein $\mathrm{C}$-deficient and one protein $\mathrm{S}$-deficient relatives, and 
Table 2. Type of the first throribotic event and age at development for the 116 symptomatic relatives

\begin{tabular}{|c|c|c|c|c|c|c|c|}
\hline \multirow[b]{3}{*}{ 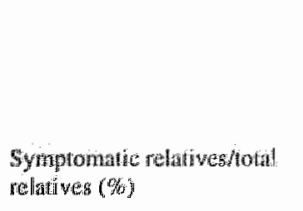 } & \multicolumn{7}{|c|}{ congulation deffect } \\
\hline & total & defoct & 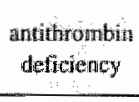 & $\begin{array}{l}\text { proteing } \\
\text { debleiency }\end{array}$ & $\begin{array}{l}\text { proteins } \\
\text { deficienty }\end{array}$ & $\begin{array}{l}\text { activated } \\
\text { protent } \mathrm{C} \\
\text { nosistence }\end{array}$ & $\begin{array}{l}\text { double } \\
\text { dofests }\end{array}$ \\
\hline & $\begin{array}{l}116723 \\
(1696)\end{array}$ & $\begin{array}{c}15 / 227 \\
(5 \%)\end{array}$ & $\begin{array}{l}30 / 85 \\
(35 \%)\end{array}$ & $\begin{array}{l}191644 \\
30 \%\end{array}$ & $\begin{array}{l}15 / 4 ! \\
(3) \% \$\end{array}$ & $\begin{array}{r}35 / 200 \\
(18 \%)\end{array}$ & $\begin{array}{c}236 \\
(335)\end{array}$ \\
\hline 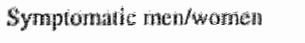 & $45 n !$ & 5110 & $16 / 14$ & $5 / 14$ & 1015 & $7 / 28$ & 210 \\
\hline $\begin{array}{l}\text { Relatives whith renows } \\
\text { thrombosithotat rewaves (\%) }\end{array}$ & $\begin{array}{l}99 / 723 \\
(146 \%)\end{array}$ & $\begin{array}{l}9 / 27 \\
(3 \%) !\end{array}$ & $\begin{array}{l}30 / 85 \\
(35 \%)\end{array}$ & $\begin{array}{l}16 / 64 \\
(25 \%)\end{array}$ & $\begin{array}{l}12 / 40 \\
2096\end{array}$ & $\begin{array}{l}30 / 200 \\
(15 \%)\end{array}$ & $\begin{array}{l}2 / 6 \\
(33 \%)\end{array}$ \\
\hline $\begin{array}{l}\text { vethots } \\
\text { thromboendbolish }\end{array}$ & $\begin{array}{l}74,99 \\
(75,96)\end{array}$ & 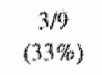 & $\begin{array}{l}27 / 30 \\
(90 \%)\end{array}$ & $\begin{array}{l}14 / 16 \\
(88 \%)\end{array}$ & $\begin{array}{l}12 / 12 \\
100 \% 2)\end{array}$ & $\begin{array}{l}17 / 30 \\
(57 \%)\end{array}$ & $\begin{array}{c}1 / 2 \\
(50 \%)\end{array}$ \\
\hline $\begin{array}{l}\text { superfictal wein } \\
\text { thrombosis }\end{array}$ & $\begin{array}{l}25 / 99 \\
(25 \% 6 \%\end{array}$ & $\begin{array}{c}6 \% 9 \\
(67 \%)\end{array}$ & $\begin{array}{l}3 / 30 \\
(10 \%)\end{array}$ & $\begin{array}{l}2 / 16 \\
(13 \%)\end{array}$ & $0 / 12$ & $\begin{array}{l}13 / 30 \\
(43 \%)\end{array}$ & $\begin{array}{c}1 / 2 \\
(50 \%)\end{array}$ \\
\hline 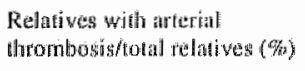 & $\begin{array}{l}17 / 23 \\
(2+2)\end{array}$ & $\begin{array}{l}6 / 237 \\
2 \% 7\end{array}$ & $0 / 85$ & $\begin{array}{r}3 / 64 \\
(50)\end{array}$ & $(7 \%)$ & $\begin{array}{l}5 / 200 \\
(3 \%)\end{array}$ & $0 / 6$ \\
\hline 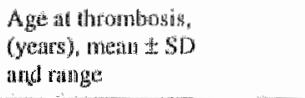 & $\begin{array}{l}34 \pm 14 \\
10-80\end{array}$ & $\begin{array}{c}40 \pm 14^{4} \\
21.62\end{array}$ & $\begin{array}{c}35 \pm 15 \\
10-77\end{array}$ & $\begin{array}{c}40 \pm 9 * \\
20-58\end{array}$ & $\begin{array}{c}40 \pm 15 \\
20 \cdots 67\end{array}$ & $\begin{array}{l}37 \pm 15 \\
15-80\end{array}$ & $\begin{array}{l}17 \pm 2 \\
15-19\end{array}$ \\
\hline
\end{tabular}

$\mathrm{p}=0.04$ compared to double defects

2 normal relatives had acute myocardial infarction; one relative with protein $C$, two with protein $\mathrm{S}$ deficiency and two normal relatives had stroke; the five relatives with activated protein $\mathrm{C}$ resistance and arterial thrombosis had transient ischemic attacks.

The mean age at the occurrence of arterial thrombosis ( 5213 years, range $23-80$ ) was higher than that at the occurrence of venous thrombosis ( 3614 years, range $10-70, p=0.0001$ ). Table 2 also shows that the age at the time of the first thrombotic episode did not differ for relatives with and without defects, varying from 35 to 40 years. The only exception was represented by the patients with double defects, who were younger than those with protein $C$ deficiency and nomal relatives $(p=0,04)$. Of the two symptomatic relatives with combined defects, one with protein $\mathrm{C}$ plus antithrombin deficiency, had deep vein thrombosis and one with activated protein C resistance plus protein C deficiency had superficial vein thrombosis.

Information about predisposing factors at the time of the first episode of thrombosis was obtained for all the 97 relatives with venous thromboembolism. Thrombosis occurred spontaneously in $45(46 \%$ ), while predisposing factors were present in $52(54 \%)$ of them. Forty-four of the 88 relatives with a coagulation defect ( $50 \%$ ) had had thromboses in the presence of predisposing factors, whose distribution was the same for the four thrombophilic defects (not shown).

\section{Lifetime risk of thrombosis}

Figure I shows the probabilities for the first thrombotic episode in the four groups of relatives with coagulation defects and in normal relatives (relatives with double defects are not shown). 


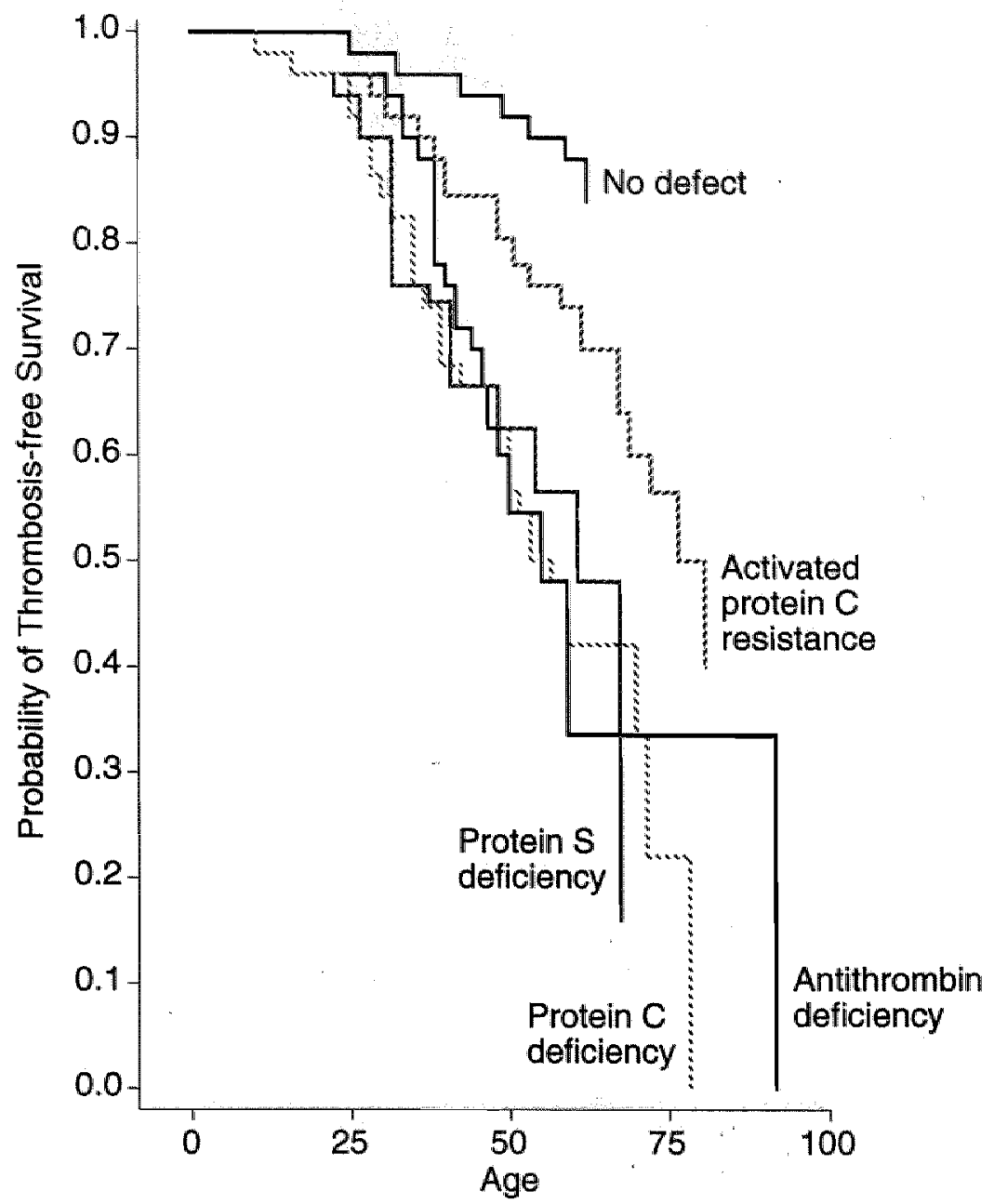

Subjects at risk (events)

$\begin{array}{lrrrr}\text { No defect } & 258(0) & 186(4) & 70(10) & 3(14) \\ \text { Antithrombin deficiency } & 64(0) & 43(1) & 11(15) & 2(18) \\ \text { Protein C deficiency } & 85(0) & 59(5) & 22(22) & 2(29) \\ \text { Protein S deficiency } & 40(0) & 27(2) & 11(12) & 1(15) \\ \text { Activated protein C resistance } & 197(0) & 146(6) & 61(24) & 8(35)\end{array}$

Figure 1. Survival was measured form birth up to each age. The probabilities of relatives with normal laboratory tests or with antithrombin, protein $C_{\text {, }}$ protein $S$ deficiencies or activated protein $C$ resistance were calculated by KaplanMeier analysis. The total number of eventsinumber of subjets at risk was $14 / 258$ for relatiwes without defect, $19 / 64$ (ior antithrombin, 30/85 for protein $\mathrm{C}, 15 / 40$ for protein $\mathrm{S}$ deficiency and 36/197 for $\mathrm{APC}$ resistance. 
A minority of relatives developed thrombosis during childhood, and the risk increasec after the age of 20 years. Both Willcoxon and log-rank tests show a significant difference in the thrombosis-free survival for all relatives $(\mathrm{p}=0,001)$, even when subdivided intc men $(p=0.008)$ and women $(p=0.004)$. The conditional relative risk of thrombosis for relatives with activated protein $\mathrm{C}$ resistance compared to that for relatives carrying al three other coagulation defects was 0.3 (95\% CI, 0.1 to 1.6), and compared to that for normal relatives was $2.2(95 \% \mathrm{CI}, 1.1$ to 4.7$)$. The risk ratio in comparison with norma: relatives was $8.1(95 \% \mathrm{Cl}, 3.4$ to 19.6$)$ for antithrombin, $7.3(95 \% \mathrm{Cl}, 2.9$ to 18.4$)$ for protein $\mathrm{C}$ and 8.5 (95\% CI, 3.5 to 20.8 ) for protein S deficiency. Since the thrombophilic defects evaluated in this study are established risk factors for venous thromboembolism but are less well-established for arterial thrombosis and superficial vein thrombosis, the analysis was also done after excluding these thrombotic manifestations. The corresponding conditional risks are summarized in Table 3.

Table 3. Risks for all thromboses (wenoug and arterial), wenous thrombosis (deep and superficial weins), and wenous thromboembolism only (deep vein thrombosis with or without punonary embolism) for relatives with andithrombin, protein C or protein S deficiencies compared to relatives with APC resistance, and the risks for relatiwes with each congulation defect compared to normal relatives. Risks are expressed as conditional melative ratios and $95 \%$ cortidenoe intervals

\begin{tabular}{lcc}
\hline & APC resistance & no defect \\
\hline $\begin{array}{l}\text { all thromboses }(n=114) \\
\text { antithrombin deficiency }(n=30)\end{array}$ & $(n=35)$ & $(n=15)$ \\
protein C deficiency $(n=19)$ & & $8.1(3.4-19.6)$ \\
protein $S$ deficiency $(n=15)$ & $0.3(0.1-1.6)$ & $7.3(2.9-18.4)$ \\
- APC resistance & & $8.5(3.5-20.8)$ \\
venous thrombosis $(n=97)$ & $(n=30)$ & $2.2(1.1-4.7)$ \\
antithrombin deficiency $(n=30)$ & & $(n=9)$ \\
protein C deticiency $(n=16)$ & $0.3(0.1-1.6)$ & $8.1(3.4-19.6)$ \\
protein $S$ deficiency $(n=12)$ & & $7.4(2.7-20.5)$ \\
- APC resistance & & $10.4(3.8-28.7)$ \\
venous thromboembolism $(n=73)$ & & $4.6(1.5-13.7)$ \\
- antithrombin deficiency $(n=27)$ & $(n=17)$ & $(n=3)$ \\
- protein C deticiency $(n=14)$ & & $42.8(10.2-180.3)$ \\
- protein $S$ deficiency $(n=12)$ & $0.3(0.2-0.5)$ & $31.3(7.0-138.8)$ \\
- APC resistance & & $35.7(7.9-160.1)$ \\
\hline
\end{tabular}

The results obtained after the exclusion of arterial thromboses did not change appreciably. When superficial vein thromboses were also excluded from the analysis, the risk of venous thromboembolism was lower for activated protein $\mathrm{C}$ resistance (risk ratio 0.3, $95 \%$ CI 0.2100 .5 ) than for antithrombin, protein $\mathrm{C}$ and protein $\mathrm{S}$ deficiencies combined. Since the probability to develop thrombosis is higher in homozygous individuals than in 
heterozygous $(6,21)$, and is lower for heparin-binding defects of antithrombin (22), the analysis was repeated after exclusion of these relatives, and the results obtained were similar to those obtained for the whole series (data not shown).

To assess the role of familial transmission of factors predisposing to thrombosis, we calculated the relative risk of thrombosis for relatives according to their belonging to a thrombophilic family. The risks of thrombosis were essentially the same for individuals belonging to an antithrombin-deficient family (risk ratio $1.2,95 \% \mathrm{Cl}, 0.8$ to 1.7 ), a protein C-deficient family $(0.9,95 \% \mathrm{CI}, 0.6$ to $\Perp .5)$ or a protein $\mathrm{S}$-deficient family (1.2, $95 \% \mathrm{CI}, 0.7$ to 1.9 ) and for those belonging to a family with activated protein $\mathrm{C}$ resistance, suggesting that the probability of developing thrombosis was rellated more to the genetic defect of the single individual than to sharing familial environmental and/or other genetic factors.

\section{DISCUSSION}

This study compared the risk for thrombosis of individuals with inherited thrombophilia due to activated protein $\mathrm{C}$ resistance or to antithrombin, protein $\mathrm{C}$ or protein $\mathrm{S}$ deficiency. We found that activated protein $\mathrm{C}$ resistance is associated with a lower risk of thrombosis and with less severe thrombotic manifestations. The probability of developing thrombosis during the lifetime was 8.1 times higher for carriers of antithrombin deficiency, 7.3 for protein $C$ deficiency and 8.5 for protein $S$ deficiency, in agreement with previous data (15). The thrombotic risk was also greater for activated protein $\mathrm{C}$ resistance, the most frequent thrombophilic defect, but its magnitude was only 2.2 times higher than that for non-carriers. This lower thrombotic tendency in carriers of activated protein $\mathrm{C}$ resistance than in individuals with deficiencies of the naturally occurring anticoagulant proteins is compatible with the biochemical mechanism of this thrombo philic defect (activated factor $\mathrm{V}$ is only partially resistant to inactivation by activated protein C) $(23,24)$.

In theory, a milder thrombophilic defect should be characterized by the onset of thrombosis at an older age and by milder clinical manifestations. The mean age at the occurrence of the first thrombotic episode were similar for all the patients with single defects, ranging from 35 to 40 years, and were also similar for men and women, and for heterozygotes and homozygotes with activated protein $\mathrm{C}$ resistance. This is in agreement with a recent observation that in heterozygous relatives with activated protein $\mathrm{C}$ resistance or protein $\mathrm{C}$ deficiency (25), differences in age at development of symptoms mainly depend on the way the patients are selected and not on the type of defect. Even so, the type of thrombotic manifestation was different for activated protein $\mathrm{C}$ resistance, with the frequency of severe manifestations, such as deep vein thrombosis and pulmonary 
embolism, being lower and that of a relatively mild manifestation, such as superficial vein thrombosis higher than for antithrombin, protein $C$ or protein $S$ deficiency. Our observations contrast with those reported by other investigators (26) who have found similar clinical manifestations in activated protein $C$ resistance and in protein $C$ or protein $S$ deficiency, despite later occurrence of the first thrombotic event in activated protein $C$ resistance. The larger number of patients tested in our study and the exclusion of index patients from the analysis probably explain the discrepancy in results.

This study included not only individuals who had venous thrombosis, but also those who had arterial thrombosis, because they are often referred to our Centers for thrombophilia screening in spite of the fact that the association between coagulation defects and arterial thrombosis is still debated (27). The prevalence of arterial thrombosis was low and was similar in the four groups ( 3 to $7 \%$ ). The mean age at the time of the first occurrence of arterial thrombosis in the relatives was higher (52 years) than that in relatives with venous episodes, indicating that carriers of thrombophilic defects are exposed to a lower risk of developing arterial thrombosis than venous thrombosis at a young age.

The risk of thrombosis was evaluated only for relatives of the index patients, to avoid a selection bias that would have led to overestimating the risk. Complete data about both coagulation tests and clinical history were available for 723 relatives. The demographic characteristics of the 490 relatives with incomplete data (only clinical or demographic information) were similar to those for personally interviewed and screened relatives. The prevalence of thrombosis was also similar for the two groups ( $20 \%$ and $16 \%$ ), suggesting that a selection bias due to lack of participation in the laboratory screening is unlikely. One possible limitation of this study may be a recall bias, since the design was retrospective. The small rate of non-objectively confirmed thrombotic events (five) and our decision to consider thrombosis as "certain" only when anticoagulant treatment had been given or signs of the postphlebitic syndrome were objectively detected should have minimized this bias. Furthermore, it is unlikely that there were differences in reporting the events for the four thrombophilic conditions. In addition to having excluded index patients from the analysis, overestimation of the risk was also minimized by the second inclusion criterion, i.e., each relative had to be tested for all four coagulation defects, since the risk for thrombosis is higher in carriers of double defects (28-31). Since the cosegregation of activated protein $\mathrm{C}$ resistance with the other inherited defects is relatively rare in Italy (32), the relatives with double defects were too few to be included in the statistical analysis. One limitation of the study may be the relatively young age of relatives, which may have led to underestimation of their lifetime risk of thrombosis.

There is at present no published randomized study and hence no established guideline on primary prophylaxis for asymptomatic individuals with activated protein $\mathrm{C}$ resistance 
exposed to predisposing factors for thrombosis $(1,27)$. We found that the lifetime risk of thrombosis for this defect is lower than that for the other three thrombophilic defects (relative ratio 0.3 ) and thrombotic symptoms are less severe. However, antithrombotic prophylaxis with unfractionated heparin or low molecular weight heparin at standard dosages should be implemented at the time of exposure of these individuals to predisposing factors for thrombosis. These views are supported by our observation that there were concurrent predisposing factors in about half of the patients with activated protein $\mathrm{C}$ resistance who developed venous thromboembolism. On the other hand, lifelong anticoagulant therapy of asymptomatic individuals with inherited thrombophilia is not considered to be justified in the absence of prospective trials demonstrating its efficacy. This view is supported by the risk of hemorrhage and cost of laboratory monitoring of anticoagulant therapy, and by the observation that mortality is not increased in individuals with antithrombin (33) or protein $\mathrm{C}$ deficiency (34) or activated protein $\mathrm{C}$ resistance (35) in comparison with the general population.

In conclusion, this family study gives the first direct answer to the question of the varying thrombotic risks of congenital coagulation defects associated with thrombophilia. Activated protein $\mathrm{C}$ resistance carries a lower risk than antithrombin, protein Cor protein $S$ deficiency, but the risk is two times that for the control group of individuals with normal coagulation. Although the age at the first thrombosis is similar for all four inherited thrombophilic defects, less severe symptoms such as superficial vein thrombosis are more frequent for activated protein $\mathrm{C}$ resistance than for the remaining defects. Obviously, our findings apply only to families in which the hereditability of the coagulation defect has been demonstrated, and not to unselected individuals.

\section{REFERENCES}

1. De Stefano V. Finazzi G, Manuncei PM. Inherited thrombophilia pathogenesis, clinical syndromes, and matuge ment. Blood 1996;87:3531-44

2. Sivensson PJ, Dahlback B. Resistance to activated protein C as a basis for venotis thrombosis. W Engl M Med $1994 ; 330: 517-22$

3. Koster $T$, Rosendali FR, de Ronde H, Briet $\mathbb{E}$, Vandenbrotcke JP, Bertina RM. Venous thombosis due lo poor anticoagulant response to activated prokein C: Leiden thrombophitia study. Lancet 1993,342:1503-6

4. Ridker: PM. Hennekens CH, Lindpanmer K. Stampfer MJ, Eisenberg PR, Miletich JP. Muntion in the gene todilg for cougulation factor $V$ and the risk of myocardial infurction, stroke, and venous thromboembolism in apparently luealthy mern. N Engl J Med 1995;332:912-7

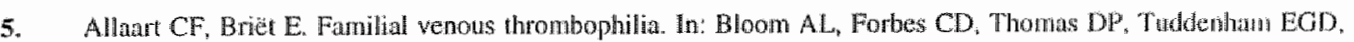
eds. Haemostasis and Thrombosis. 3rd ed. vol 2. Edinburgh: Churchill Livingstone; $1994: 1349$-60

6. Lame DA. Mannucci PM, Bauer KA, Bertina RM, Bochkov NP, Bowlyjenkov V, ct al. Inherited thromilbophilia part 1. Thromb Hemost 1996;76:651-62 


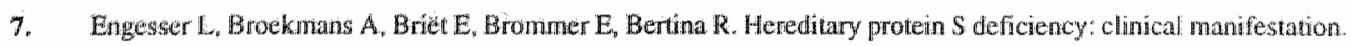
Arn Jitcri Med 1987:106:677\%82

8. Bovill EG, Batur KA, Oickeman JD, Callis P. West B. The chinical spectrmof heterozygous protein C deficiency in a large New England kndred. Blood $1989 ; 73: 712-7$

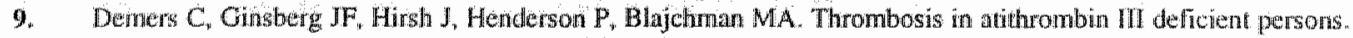
Repoit of a linge kindred and literature review. Am Intern Med 1992;116:754-61

10. Allati CF, Poort SR, Rosendaral FR, Reisma PH, Bertina RM, Briat E Incrased rial of wenous thrombosis in cartiers of protein $C$ deficitency defect. Lancet 1993,341:1134-8

11. Koster T, Rosendan FR, Bridt E, van der Meer J, Colly LP, Trienckens $\mathrm{PH}_{\diamond}$ et al. Protein C deficiency in a controlled series of unselected oupatients: an infrequent but clear rish factor for venous thrombosis (Leiden thrombophilia study). Blood 1995;85:2756-61

12. Hejboer H, Brandjes DP, Buller HR, Sturk A, ten Cate JW. Deficiencies of congulation-inhibiting and fubrinolytic proteins in outpatients wh deep-vein thrombosis. N Engl J Med 1990;323:1512-6

13. Tail RC, Walker ID, Perry DJ, Catrell RW, Islam SIA, MCCall F, et al. Prevalence of antithrombin III deficiency sublypes in 4000 healthy blood donors. Thromb Hasmost 1991:65:839

14. Koster $T$, Rosendal FR, de Ronde H, Brièt E, Vandenbroucke JP, Bertina RM. Venous thrombosis due to poor anticotgulant response to activated proten C. Leiden Thrombophilia Study. Lancet 1993,342:1503 6

15. Pabinger 1, Schneider B, for the GTH Study Group on Natural Inhibitors. Thrombotic risk in hereditary antiturombin III, protein $C$, or protein $S$ deficiency. A cooperatiwe retrospective study. Arterioscler Thromb Vaso Biol $1096: 16: 742+3$

16. Frezato M, Tosetlo A, Rodeghiero F. Validated questionnaire for the identification of previous personal on familial venous thromboembolism. Am J Epidemiol 1996"143: 1257-65

17. Sas G, Pepper DS, Cash JD. Plasma and serum antithrombin Ifl: differentiation by crossed immunoelectrophoresis. Thromb Res $1975 ; 6: 87-91$

18. Comp PC, Doray D, Patton D, Esmon CT. An abnormal plasma distribution of protein Soccurs in functional protem S defficiency. Blood 1986;67:504-8

19. Berting RM, Koeleman RPC, Koster T, Rosendaal FR, Dirven RJ, de Ronde H, et al Mutation in blood congulafion factor $V$ associated with resistance to activated protein $C$. Nature $1994 ; 369 ; 64-7$

20. SAS instituie. Version 6, fouth edition, 1990

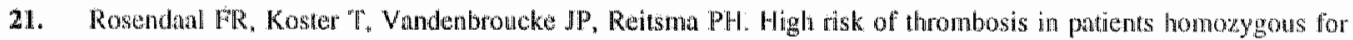
factor $V$ luciden (auctivated protein C resistance). Blood 1995;85:1504-8

22. Finazi $G$, Caccia $R$, Bubui T. Diffenen prevalence of thromboembolism in the subtypes of congental antionrombin III deficianey: review of 404 cases. Thromb Hanost $1987,58: 1094$

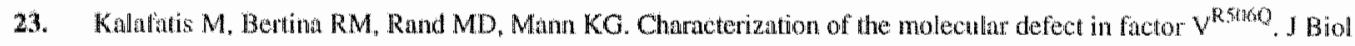
Chem 1995:270:4053\%7

24. Hew MJ. Kojina Y, Greengard JS, Griffin JH. Activated protein C resistance: molecular medhamisms based on sturlies using purifed Gint ${ }^{50}$ - functor V. Blood 1995;85:3405-11

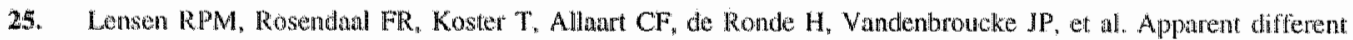
thrombotic tendency in patients with factor $\mathrm{V}$ Leiden and protein $\mathrm{C}$ deficiency due to seleation of patients. Blood $1996: 88: 4205-8$

26. Leroy-Mathenon C. Lewent M, Pignon JM. Mendonca C, Gotault-Heilmann M. The 1691 GiA mution in the factor $\checkmark$ gene: relationship to activated protein $C$ (APC) resistance and thrombosis in 65 patients. Thromb Haenost $1996,75: 4-10$

27. Lane DA. Monmucci PM, Bauer KA, Bertina RM, Bochkov NP, Boulyjenkov V, et al. Inherited thrombophilia: 
part 2. Thromb Haemost 1996:76:824-34

28. Koeleman BPC, Reitsma PH, Allart CF, Bertina RM. Factor V Leiden an additional nisk fator for thronbosis in protein C deficien families. Blood 1994; 84:1031-5

29. Zöler B, Bemstdotter A, Garcia de Fontos , Dahlbäck B. Resistance to activated protein C as an additional genchic risk factor for thrombosis in hereditary deficiency of protein $S$. Blond $1995,85,3518,2 \%$

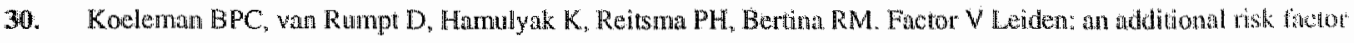
for thrombosis in protein S deficient families? Thomb Hamost 1995; 4:580-3.

31. wan Bowen HH, Reitsma PH, Rosendat FR, Bayston TA, Chowdhury V, Buder KA, et al. Factor W Leiden (FV $\mathrm{R} 5060$ ) in families with inherited antithrombin defieiency. Thromb Haemost 1996:75:417-21

32. Martinelli I, Magatelli R, Cattaneo M. Mamncei PM. Prevalence of mutant Foror $W$ in Italian paticuts with herediary deficiencies of antithrombin, protein $\mathrm{C}$ or protein S. Thromb Haenost 1996;75694.

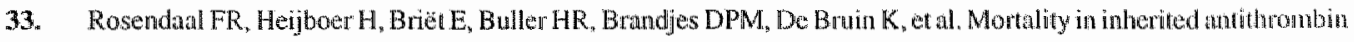
III deficiency - 1830 to 1989. Lancet 1991;337:260-2

34. Allar CF, Rosendaal FR, Noteboon WMP, Briet E. No excess mortality in heterozygotes for hereditury moten C. deficiency type $1-1820$ to 1993. Thromb Haemosi 1995;73:1252

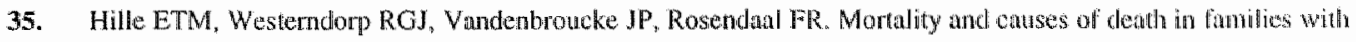
the factor $V$ Leiden mutation (resistance to activated protein C). B100d 1997:89:1963-67 


\section{Chapter 4}

\section{HEIGHTENED THROMBIN GENERATION IN INDIVIDUALS WITH RESISTANCE TO ACTIVATED PROTEIN C}

Ida Martinelli, Bianca Bottasso, Francesca Duca, Elena Faioni, Pier Mannuccio Mannucci

"A. Bianchi Bonomi" Hemophilia and Thrombosis Center, Institute of Internal Medicine, IRCCS Ospedale Maggiore, University of Milan, Italy

Thromb Haemost 1996;75:703-5 


\section{SUMMARY}

We chose to evaluate whether or not a state of biochemical hypercoagulability was present in 74 individuals ( 69 heterozygotes and 5 homozygotes) resistant to activated protein C (APC) due to the Arg506 GIn mutation in the factor $V$ gene. To this end, plasma levels of two markers of thrombin formation, prothrombin fragment $1+2(\mathrm{~F} 1+2)$ and thrombin-antithrombin complexes (TAT), were measured.

High levels of F1+2 and TAT were found in $32 \%$ and $23 \%$ of APC-resistant individuals ys $4 \%$ in controls. The levels of this markers tended to be particularly elevated in the 5 homozygous subjects. No relationship between marker values and the previous occurrence of thrombotic episodes was found. A significant positive correlation between F1+2 and TAT was present in APC-resistant subjects.

Therefore, by measuring FI+2 and TAT a state of biochemical hypercoagulability has been identified in about one-third of APC-resistant individuals. This frequency is similar to that previously observed in comparable individuals with inherited deficiencies of protein $C$ and protein $S$, which are usually associated with a stronger thrombotic tendency than APC-resistant individuals.

\section{INTRODUCTION}

Hypercoagulability can be biochemically defined as a condition of procoagulant imbalance due to heightened activity of coagulation enzymes in the absence of laboratory and clinical signs of fibrin formation (1). This situation may be detected by measuring plasma markers of coagulation activation, such as peptides cleaved from coagulation zymogens when they are transformed into active enzymes or complexes formed between coagulation enzymes and their naturally occurring inhibitors (2).

An inherited hemostatic defect characterized by the relative resistance of activated factor $V$ to the inactivation by activated protein $C$ (APC) has been identified (3).

A point mutation at position 1691 in the gene coding for factor $V(4)$, that slows the cleavage of activated factor $\mathrm{V}$ by $\mathrm{APC}$, is responsible for APC resistance. Although APC resistance has been clearly associated with an increased thrombotic risk, very little information on whether or not there is a state of heightened coagulation activation in APC-resistant individuals is available so far (5).

We chose to investigate this problem by measuring two markers of thrombin formation, prothrombin fragment $1+2(\mathrm{~F} 1+2)$ and thrombin-antithrombin complexes (TAT). "The former measures thrombin generated upon the action of activated factor $\mathrm{X}$ on prothrombin, the latter measures thrombin that formed complexes with its main naturally occurring inactivator. 


\section{PATIENTS AND METHODS}

\section{Patients}

Twenty-three index patients (median age: 30 years, range 18-59) referred to our Thrombosis Center from Jamuary 1994 and March 1995 were consecutively diagnosed as having APC resistance. A family study was carried out in 15 of them and 51 APC-resistant relatives were identified.

The median age of the relatives ( 32 years, range $11-76$ ) at the time of blood sampling was not significantly different from that of index cases. Of the whole cohort of 74 APC-resistant individuals, 5 were homozygous and 69 were heterozygous for mutant factor $\mathrm{V}$.

Thirty individuals ( $41 \%$ ), the 23 index patients ( 21 heterozygotes and 2 homozygotes) and 7 relatives ( 6 heterozygotes and 1 homozygotes), had previously experienced at least one objectively diagnosed thrombotic episode, in a venous site in 28 and in an arterial site in 2 .

None of the patients was on oral anticoagulant treatment at the time of blood sampling, and none had clinical or laboratory evidence of autoimmune diseases, myeloproliferative disorders or cancer.

\section{Blood sampling}

Blood samples were collected into $0.129 \mathrm{~mol} / \mathrm{L}$ trisodium citrate-containing evacuated tubes. Samples were centrifuged within 30 minutes at $3000 \mathrm{~g}$ and at $4^{\circ} \mathrm{C}$. The platelet-poor plasma was snap-frozen and stored in aliquots at $-80^{\circ} \mathrm{C}$ for no more than 1 month until assays were carried out.

\section{Laboratory tests}

The presence of mutant factor $\mathrm{V}$ was evaluated by DNA analysis according to the method of de Ronde et Bertina (6). F1+2 was assayed by a commercial ELISA (Behringwerke, Marburg, Germany), which is based upon the sandwich principle and uses as a capture antibody a rabbit polyclonal antibody raised against a synthetic peptide containing 14 amino acids located within the carboxyterminal end of $F 1+2$.

The second antibody is an anti-human prothrombin rabbit antibody. TAT complexes were assayed by the commercial ELISA method Enzygnost TAT (Behringwerke, Marburg, Germany), which is also based on the sandwich principle and uses as a capture antibody a rabbit polyclonal antibody against thrombin-antithrombin complexes, and a 
anti-human antithrombin polyclonal second antibody.

The upper limits of the normal range for F1+2 and TAT $(0.52 \mathrm{nmol} / \mathrm{L}$ and $5.22 \mathrm{ng} / \mathrm{L})$ correspond to the 95th percentiles of the distribution of values in 69 healthy volunteers who matched for sex and age with the index subjects.

Coagulation abnormalities other than APC resistance predisposing to thrombosis, i.e., antithrombin, protein $\mathrm{C}$, protein $\mathrm{S}$ deficiencies and antiphospholipid antibodies, were excluded in all the APC-resistant subjects using previuosly described methods (7).

\section{Statistical analysis}

Since plasma levels of F1+2 and TAT were not normally distributed, they were transformed logarithmically to approximate normal distribution.

The Student's t-test was used to compare values of markers in APC-resistant heterozygotes with those in the age- and sex-matched healthy controls.

Fisher's exact test was used to correlate plasma levels of F1+2 and TAT complexes with a previous history of thrombosis.

A linear regression model was used to calculate the relationship between $\mathrm{FI}+2$ and TAT in APC-resistant heterozygotes and controls.

\section{RESULTS}

In the 5 APC-resistant homozygotes ( 3 with and 2 without a history of thrombosis) both $\mathrm{F} 1+2$ and TAT were elevated in three instances but were within the normal limit in the remaining two. (Table 1).

Table 1. Protliombin frament $1+2$ and thrombin-ant thrombin complexes in homozygous individuals

\begin{tabular}{lccc}
\hline initials & F $1+2(\mathrm{nmol} / \mathrm{L})$ & TAT $(\mathrm{ng} / \mathrm{mL})$ & $\begin{array}{c}\text { previous thrombotic } \\
\text { episodes }\end{array}$ \\
\hline TP & 1.77 & 6.4 & none \\
SE & 1.56 & 4.6 & ST T $^{*}$ \\
$\mathrm{SL}$ & 2.72 & 12.8 & $\mathrm{ST}$ \\
$\mathrm{ST}$ & 2.13 & 10.3 & none \\
AA & 1.4 & 4.2 & DVT \\
\hline normal range & $0.52-1.58$ & $1.2-5.2$ & \\
\hline
\end{tabular}

*ST $=$ superficial thrombophlebitis, "DVT=deep vein thrombosis 
Figure 1 shows the results of hypercoagulability markers for APC-resistant heterozygotes ( 69 for $\mathrm{F} 1+2$ and 68 for TAT).
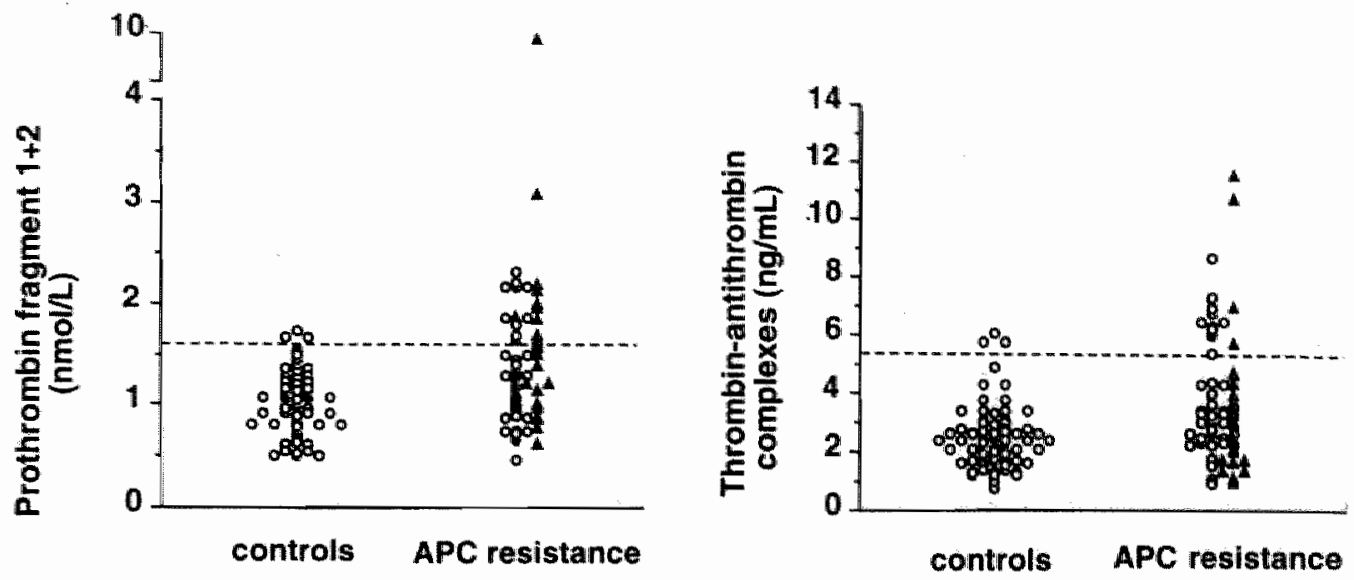

Figure 1. Prothrombin fragment $1+2$ and thrombin-antithrombin complexes in $A P C$-resistant individuals and sex-and age-matched controls. Open circles represent asymptomatic cases, closed triangles symptomatic cases. Dashed line indicates the upper limit of the normal range

Among them, 21/69 (30\%) had elevated F1+2 levels and 16/68 (24\%) had elevated TAT levels, compared to $3(4 \%)$ and $3(4 \%)$ in the control group. Differences between the median values for APC-resistant individuals and controls were statistically significant for both markers (Table 2).

Table 2. Prothrombin fragment $1+2$ and thrombin-antithrombin complexes in individuals with mutant factor $V$ and controls (median values and ranges)

\begin{tabular}{|c|c|c|c|c|}
\hline & \multirow[b]{2}{*}{ all } & \multicolumn{2}{|c|}{ heterozygotes for mutant factor $V$} & \multirow[b]{2}{*}{$\begin{array}{l}\text { matched } \\
\text { controls }\end{array}$} \\
\hline & & $\begin{array}{l}\text { with previous } \\
\text { thrombosiss }\end{array}$ & $\begin{array}{l}\text { without previous } \\
\text { thrombosis }\end{array}$ & \\
\hline prothrombin tragment $1+2$ & $1.24 *$ & $1.39 *$ & 1.184 & 1.08 \\
\hline (nmol/L) & $(0.47-10.1)$ & $(0.62-10.1)$ & $(0.47-2.33)$ & $(0.5-1.73)$ \\
\hline (normal range $0.52-1.58$ ) & $n=69$ & $\mathrm{n}=27$ & $n=42$ & $n=69$ \\
\hline thrombin-antithrombin & $3.3^{*}$ & 3.1\# & $3.35^{*}$ & 2.4 \\
\hline complex $(\mathrm{ng} / \mathrm{mL})$ & $(0.9-11.5)$ & $(0.9 \times 11.5)$ & $(0.9-8.7)$ & $(0.8-6.1)$ \\
\hline (normal range $1.2-5.2$ ) & $\mathrm{n}=68$ & $n=26$ & $n=42$ & $n=69$ \\
\hline
\end{tabular}

$* p<0.0005, p<0.05$ vs age- and sex-matched controls 
There was no relationship between values of hypercoagulability markers and the presence or absence of previous thrombotic episodes (Figure 1). Seven APC-resistant individuals ( 3 with previous thrombosis) had increased levels of both markers, while 14 ( 8 with previous thrombosis) and 9 ( 1 with previous thrombosis) had increased levels of only $\mathrm{F} 1+2$ or TAT. A significant positive correlation between $\mathrm{F} 1+2$ and TAT was found in APC-resistant heterozygotes $(r=0.31, p<0.01)$ but not in controls $(r=0.05, p>0.1)$.

\section{DISCUSSION}

This study demonstrates that a state of hypercoagulability, revealed by measuring markers of heightened thrombin formation such as F1+2 and TAT complexes, is present in about one-third of individuals with APC resistance diagnosed by demonstrating the presence of the mutant factor $V . F 1+2$ has been previously measured in a cohort of patients with cerebrovascular disease, showing that in those with mutant factor $\mathrm{V} \mathrm{FI}+2$ values were not higher than in those with no mutation (5). Nevertheless, the very small sample of patients with mutant factor $V$ ( 6 heterozygotes) does not allow to draw firm conclusions from that study. High values of $F 1+2$ have been al so found in a family with APC resistance which included homozygous and heterozygous members (8).

Our findings of a relatively high prevalence of biochemical hypercoagulability, not only in homozygotes but even in heterozygotes, is somewhat surprising from a mechanistic standpoint. The mutation at Arg 506, one of the two sites of cleavage of activated factor $\mathrm{V}$ by activated protein $\mathrm{C}(9)$, slows by about ten times the rate of inactivation of this procoagulant moiety (10). Yet, inactivation is not totally abolished in these individuals, because the other site of cleavage of activated factor V at Arg 306 remains intact (10). In theory, the inherited deficiencies of the zymogen and main cofactor of APC, protein $C$ and protein $S$, should cause a more marked impairment of the protein $C$ anticoagulant mechanism and a more severe state of biochemical hypercoagulability than the mutant factor $\mathrm{V}$. Although in this study we did not compare directly APC-resistant individuals with protein $\mathrm{C}$ - and protein $\mathrm{S}$-deficient individuals, $\mathrm{F} 1+2$ has been previously measured by the same method in our laboratory in a series of individuals heterozygotes for protein $\mathrm{C}$ and protein $\mathrm{S}$ deficiencies (11). In them, the prevalence of abnormally high F1+2 values ( 25 and $29 \%$ respectively) was not greater than in the APC-resistant heterozygotes examined in this study $(30 \%)$. The protein $\mathrm{C}$ - and protein $\mathrm{S}$-deficient individuals were selected with criteria similar to those used in this study for APC-resistant individuals (11). In addition, they were similar for variables that may affect the plasma levels of activation markers, such as median age (28 years, range $9-74$ for protein $\mathrm{C}$ - and protein S-deficient individuals \&s 32 years, range 11-76 for these APC-resistant individuals) and for the presence of a personal history of thrombosis (50\% in protein C- and

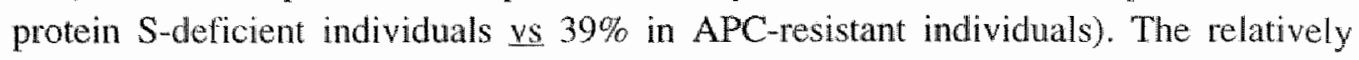


frequent finding of hypercoagulability in APC-resistant heterozygous individuals is also surprising clinically, considering that the factor $V$ mutation per se engenders a relatively weak thrombotic tendency $(8,12)$. The levels of $F 1+2$ appeared quite high in three of the five homozygotes studied by us, and whether or not a particularly marked state of hypercoagulability is present in some homozygotes remains to be established by larger studies. Another apparent paradox is the fact that individuals with antithrombin deficiency, who develop thrombosis with similar or higher frequency and severity as those with the other defects of the protein $C$ anticoagulant system (13), have biochemical signs of hypercoagulability less frequently $(11,14)$.

On the whole, it appears that the clinical significance of heightened coagulation activation in individuals with inherited thrombophilic syndromes remains uncertain, and the results of ongoing prospective studies are awaited to establish whether or not activation markers predict the occurrence of thrombotic episodes.

\section{REFERENCES}

1. Baten KA, Rosenberg R.D. The pathophysiology of the prethrombotic state in humans: insights gained from studies using markers of the hemostatic systent actiwation. Blood 1987; 70:343-50

2. Mannucci PM. Mechanisms, markers and management of coagutation actiwation. Br Med $13411.1994 ; 50: 851-70$

3. Dahbuck B, Carlsson M, Svensson PJ. Familial thrombophilin due to a previously unecognized meethanism characterized by poor anticoagulant response to activated protein $\mathrm{C}$ : prediction of a cofictor to activalied protain $\mathrm{C}$. Proc Natl Acad Sci USA 1993; 90: 1004-8

4. Bertina RM, Koeleman RPC, Koster T, Rosendaal FR, Dirven RJ, de Ronde H, van der Velden PA, Reitsma PH. Mutation in blood coagulation factor $W$ associated with lesistance to actiwated protein $C$. Nature 1994;, 369: 64.7

5. Catto A, Carter A, Ireland H, Bayston TA, Philippou H, Barret J, Lane DA, Gran PJ. Factor V Leiden gene inutation and thrombin generation in relation to the development of acute stroke. Artariosel Thromb Wase Biol 1905; 15 : $783-5$

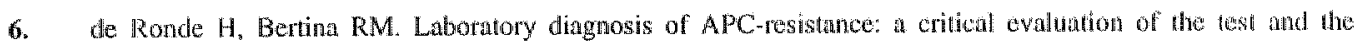
development of diagnostic criteria. Thromb Hatmost 1994:72:880.6

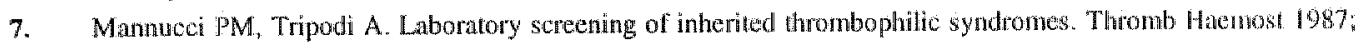
57: $247-51$

8. Greengard JS, Eichinger $S_{*}$ Griffin JH, Bater KA. Wariability of thrombosis among homozygots siblinges with resistance to activated protein C due to Arg-Gln mutation in the gene for factor $\mathrm{V}$. N Engl J Med $1994: 331: 1559-62$

9. Kalafatis M, Rand MD, Mann KG. The mechanism of inactivation of human factor and Inuman fautor $\mathrm{Wat}$ by achuated protein C. IBiol Chen 1994; $269: 3869-80$

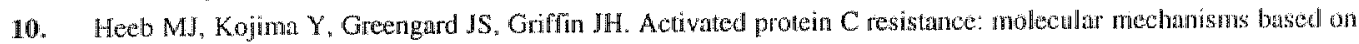
studies using purified Gln 506 - factor V. Blood 1995; 85:3405-1॥

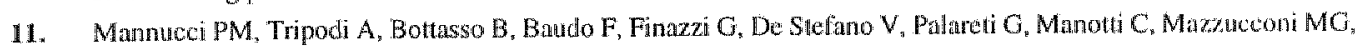
Castaman GC. Markers of procoaguan imbalance in patients with inheribed thrombophilic symdromes. Theromb Haemost 1992; 67:200-202

12. Martinelli I. Faioni $\mathbb{E M}$, Monzani $M L$, Mannucci PM. Inherited resistance 10 activated protein C (A PC): vinicul and llaboratory features. Blood $1.994 ; 10$, suppl 1: 84a 
14. Finazz $\mathrm{O}$, Barbui $T$. Different incidence of venous thrombosis in paiients with inherited deficiencies of antithrombin III, protern C and protein S. Thromb Hatemost 1994; $71: 1.506$

15. Bawer KA, Bartegar $\$$, Rosenberg RD. Influence of articoagulants used for blood collection on plasma prothrombin fragnent $1+2$ measurements. Thromb Res $1991 ; 63 ; 617-28$ 


\section{Chapter 5}

\section{RISK FACTORS FOR RARE MANIFESTATIONS OF VENOUS THROMBOSIS}

Factor $\mathrm{V}$ gene mutation is a risk factor for cerebral venous thrombosis Thromb Haemost 1996; 75: 393-4

Oral contraceptives are a risk factor for cerebral vein thrombosis Thromb Haemost 1996; 74: 477-8

Risk factors for deep venous thrombosis of the upper extremities Ann Intern Med 1997; 126: 707-11

Low prevalence of factor $\mathrm{V}: \mathrm{Q} 506$ in patients with isolated pulmonary embolism Thromb Haemost 1997; 77: 440-3 


\section{FACTOR V GENE MUTATION IS A RISK FACTOR FOR CEREBRAL VENOUS THROMBOSIS}

Ida Martinelli", Gianluca Landi², Giuliana Merati", Ermelinda Cella", Alberto Tosetto ${ }^{3}$, Pier Mannuccio Mannucci ${ }^{1}$

l“A. Bianchi Bonomi" Hemophilia and Thrombosis Center, Institute of Internal Medicine and

${ }^{2}$ Neurology Clinic, IRCCS Ospedale Maggiore University of Milan, and ${ }^{3}$ Hemophilia and Thrombosis Center, S.Bortolo Hospital, Vicenza, Italy

Thromb Haemost 1996;75:393-4 


\section{SUMMARY}

To evaluate the association between coagulation defects and cerebral venous thrombosis, we investigated a cohort of 25 patients who had no autoimmune, neoplastic or infectious disease and 75 healthy individuals in a case-control study. No patient had deficiency of protein $\mathrm{C}$ or protein $\mathrm{S}, 4$ had resistance to activated protein $\mathrm{C}$ (APC) and one had APC resistance associated with antithrombin deficiency. APC resistance was diagnosed by DNA analysis, when a point mutation in the factor $\mathrm{V}$ gene, predicting replacement of Arg506 with Gln at one of the two APC cleavage sites in activated factor $\mathrm{V}$, was present. The prevalence of APC resistance was $20 \%$ in patients and $2.7 \%$ in controls. This difference was statistically signficant $(\mathrm{p}=0.01)$ and the odds ratio was 9.1 . A circumstantial predisposing factor at the time of cerebral venous thrombosis (such as oral contraceptive intake, pregnancy or puerperium, trauma or prolonged immobilization) was reported in $72 \%$ of cases. In conclusion, APC resistance is the most frequent coagulation abnormality associated with cerebral venous thrombosis.

\section{INTRODUCTION}

Inherited resistance to activated protein $\mathrm{C}(\mathrm{APC})$ is a recently identified coagulation defect linked in most instances to a point mutation in the gene coding for the procoagulant factor $V$, predicting replacement of Arg506 with Gln (1). The resulting activated form of mutant factor $\mathrm{V}$ is partially resistant to the inactivation by $\mathrm{APC}$, its naturally occurring inhibitor (2). APC resistance has been associated with a 5- to 10-fold increased risk of superficial and deep vein thrombosis of the lower limbs and pulmonary embolism $(1,3)$, but it is unknown whether APC resistance predisposes to cerebral venous thrombosis. We therefore investigated in this case-control study a cohort of patients with cerebral venous thrombosis for the presence of the mutant factor $\mathrm{V}$.

\section{PATIENTS AND METHODS}

Patients. We investigated a consecutive series of 25 patients with cerebral venous thrombosis referred between January 1985 and April 1995 to the Hemophilia and Thrombosis Center of Milan for a coagulation screening. No patients had autoimmune or neoplastic disease, and the only patient who had developed cerebral venous thrombosis after local infection (acute otitis) was excluded. Diagnosis was established by a neurologist on the basis of intraarterial angiography in 17 cases, intravenous digital angiography in one case, MR imaging in 6 cases, and in one patient by a CT scan showing the typical delta and cord signs (4). Four patients presented with the clinical picture of chronic isolated intracranial hypertension (i.e. headache, papilledema, and in two cases a th 
uerve palsy), whereas the remaining $2 l$ cases had various combinations of focal neurological deficits, seizures, and decreased level of consciousness. There was no case of cavernous sinus thrombosis; 11 patients had radiological evidence of thrombosis of one dural sinus only (with an associated cortical venous thrombosis in 4 cases), the remaining 14 patients of two or more sinuses.

Controls. Three healthy controls from the general population who matched for sex and age ( \pm 5 years) with each patient were chosen. Previous thrombotic episodes were excluded on the basis of a structured questionnaire validated for its accuracy to diagnose retrospectively venous thromboembolism (5).

Laboratory tests. Blood samples were drawn into vacuum tubes containing sodium citrate 3.8 (w/vol) as anticoagulant. Mutant factor $V$ was determined by DNA analysis in patients and controls, according to the method of de Ronde et Bertina (6). Briefly, a 220 bp fragment of exon10/intron 10 of the factor $V$ gene is amplified by PCR, using 5'-TGGCCAGTGCTTAACAAGACC-3' as the 5' primer and 5'-CTTGAAGGAAATGCCCCATTA-3' as the 3" primer. Amplification involved 36 cycles of $91^{\prime \prime C}$ $(40 \mathrm{sec}), 55^{\prime \prime} \mathrm{C}(40 \mathrm{sec})$ and $71^{\prime \prime} \mathrm{C}(2 \mathrm{~min})$ in the presence of $2 \mathrm{U}$ Taq polymerase. Subsequently the $220 \mathrm{bp}$ fragment is digested during 16 hours by $0.4 \mathrm{U} \mathrm{MnlI}$ at $37^{\circ} \mathrm{C}$. Mnll digests the 220 bp fragment of the wild factor $V$ allele in three fragments of 37,67 and 116 bp each. The mutant factor $V$ allele is cleaved only in two fragments of 67 and $153 \mathrm{bp}$, respectively. Finally, the digestion products are separated by electrophoresis on ethedium bromide stained $2 \%$ agarose gels for $30 \mathrm{~min}$ at $150 \mathrm{~V}$.

In addition, a laboratory screening for antiphospholipid antibodies, antithrombin, protein $\mathrm{C}$ and protein $\mathrm{S}$ deficiencies has been performed in patients as previously described $(7,8)$. In those on oral anticoagulant treatment at the time of blood sampling, only mutant factor $V$ and antithrombin were evaluated.

Statistics. As an approximation of the relative risk, crude odds ratio (OR) was calculated for mutant factor $\mathrm{V}$ by simple cross-tabulation. This odds ratio reflects the risk of thrombosis when the mutant factor $\mathrm{V}$ is present relative to the risk when it is absent, unadjusted for other factors. The statistical significance of the odds ratios were evaluated by chi-square tests or Fisher's exact test. The $95 \%$ confidence intervals (CI) were calculated when needed.

\section{RESULTS}

No homozygote for the mutant factor $V$ was found in cases and controls. Heterozygosity was detected in $5 / 25$ patients with cerebral venous thrombosis $(20 \%, 95 \% \mathrm{CI}: 6.8-40.7)$ and in $2 / 75$ controls $(2.7 \%, 95 \% \mathrm{CI}: 0.3-9.3)$. This difference is statistically significant (OR: 9.1 , $95 \% \mathrm{Cl}: 1.6-50.5 ; \mathrm{p}=0.01)$. The main characteristics of cases are listed in Table 1. 
Table 1. Main characteristics of patients

\begin{tabular}{|c|c|c|c|c|}
\hline patient & $\operatorname{sex}$ & $\begin{array}{l}\text { age at the time } \\
\text { of thrombosis }\end{array}$ & $\begin{array}{l}\text { circumstantial } \\
\text { risk factors }\end{array}$ & $\begin{array}{c}\text { APC } \\
\text { resistance }\end{array}$ \\
\hline I & $\mathrm{M}$ & 51 & immobilization & yes \\
\hline 2. & M & 64 & none & no \\
\hline 3 & $\mathrm{~F}^{i}$ & 34 & pregnancy & no \\
\hline 4 & $\mathrm{~F}$ & 27 & oral contraceptives & no \\
\hline 5 & $\mathrm{~F}$ & 32 & oral contraceptives & no \\
\hline 6 & $\mathrm{~F}$ & 28 & oral contraceptives & no \\
\hline 7 & $\mathrm{~F}$ & 42 & oral contraceptives & no \\
\hline 8 & $\mathrm{~F}$ & 29 & oral contraceptives & yes \\
\hline 9 & M & 25 & none & yes \\
\hline 10 & $F$ & 33 & puerperium & no \\
\hline I1] & $\mathrm{F}$ & 43 & none & no \\
\hline 12 & F & 44 & none & no \\
\hline 13 & $\mathrm{~F}$ & 21 & oral contraceptiwes & no \\
\hline 14 & $\mathrm{~F}$ & 54 & none & no \\
\hline 15 & $\mathrm{~F}$ & 28 & puerperium & 170 \\
\hline 16 & $\mathrm{~F}$ & 28 & oralcontraceptives & no \\
\hline 17 & $\mathrm{M}$ & 27 & none & no \\
\hline 18 & $\mathrm{~F}$ & 31 & puerperium & yes \\
\hline 19 & $F$ & 24 & none & no \\
\hline 20 & $\mathrm{M}$ & 32 & none & no \\
\hline 21 & $\mathrm{~F}$ & 39 & oral contraceptives & yes \\
\hline 22 & $\mathrm{~F}$ & 24 & oral contraceptiwes & no \\
\hline 23 & $\mathrm{~F}$ & 23 & oral contraceptiwes & no \\
\hline 24 & $\mathrm{~F}$ & 38 & oral contraceptives & no \\
\hline 25 & $\mathrm{~F}$ & 43. & oral contraceptives & 110 \\
\hline
\end{tabular}

Twenty $(80 \%)$ were females and the median age at the time of thrombosis was 32 years (range 21-64). Circumstantial risk factors known to predispose to cerebral venous thrombosis (9), such as current oral contraceptive intake, pregnancy or puerperium, prolonged immobilization or trauma were reported in 18 patients $(72 \%)$. Mutant factor $\mathrm{V}$ was the sole risk factor in one patient whereas it was associated with circumstantial risk factors in the remaining four. Oral contraceptive use was found in $12 / 20(60 \%)$ patients us $25 / 60(42 \%)$ controls (OR: $2.1,95 \% \mathrm{CI}: 0.8-5.9, \mathrm{p}=0.24$ ). The median interval between the beginning of oral contraceptive use and the onset of cerebral venous thrombosis was 7 months (range 2-75). Cerebral wenous thrombosis was the first thrombotic event in 23 patients, whereas 2 had had previous venous thrombosis of the lower limbs. One patient developed a second episode of cerebral venous thrombosis one year after the first. 
No patients had defictency of protein $C$ or protein $S$ or antiphospholipid antibodies. The patient with antithrombin deficiency had concomitantly mutant factor $\mathrm{V}$.

\section{DISCUSSION}

$A P C$ resistance is characterized by a lower sensitivity of the activated factor $V$ to the anticoagulant action of APC (2). In most cases, responsible of the defect is a single point mutation in the factor $\mathrm{V}$ gene $(\mathrm{G} \rightarrow \mathrm{A}$ at nucleotide 1691$)$, which predicts replacement of arginine with glutamine at position 506, one of the two APC cleavage sites in activated factor V (1). Family studies demonstrated that the defect is inherited as an autosomal dominant trait and is correlated with a 10 -fold increased risk of venous thrombosis. While genetic defects of antithrombin, protein $\mathrm{C}$ and protein $\mathrm{S}$ are together found in only 5-10\% of unselected patients with venous thromboembolism, the estimated prevalence of mutant factor $\mathrm{V}$ is about $20 \%(1,3)$. The defect is also common in the general population $(3-5 \%)$ (3). Although several case reports have described the association between cerebral venous thrombosis and deficiency of antithrombin, protein $C$ or protein $S(10)$, this is the first study which evaluated the prevalence of APC resistance and other coagulation abnormalities predisposing to thrombosis in a series of patients with cerebral venous thrombosis. This study may be affected by a selection bias due to referral of cases to our Center from different neurological departments. We could establish that the patients were consecutively admitted only for those referred from the neurological clinic of our hospital in Milan (13/25). Nevertheless, the characteristics of patients admitted to our hospital were similar for age, sex and clinical presentation to those of patients admitted to others.

By analogy with previous observations that cerebral venous thrombosis often occurs in the presence of predisposing factors (11), the rate of spontaneous events in our series, i.e., without coagulation abnormalities and circumstantial risk factors, was less than $30 \%$. Since in developed countries oral contraceptive intake is frequently associated with cerebral venous thrombosis, it is commonly considered as a risk factor $(12,13)$. To our knowledge, there are no previous studies which compared oral contraceptives in patients with cerebral venous thrombosis and healthy controls, and their use in our two groups was not significantly different.

Anticoagulant treatment in patients with cerebral venous thrombosis is controversial, but there is good evidence that heparin treatment is beneficial $(11,14)$. In general, individuals with $\mathrm{APC}$ resistance but with no other coagulation defects are treated like patients with deficiencies of protein $\mathrm{C}$, protein $\mathrm{S}$ or antithrombin. By analogy with deep vein thrombosis, our strategy is to anticoagulate all the patients with cerebral venous thrombosis for three months, and to give a more extended therapy (up to one year) when a coagulation defect is identified. We decided to put on lifelong anticoagulant therapy 
the patient who had mutant factor $V$ associated with antithrombin deficiency and those who had had more than one thrombotic episode.

In conclusion, APC resistance due to heterozygous mutant factor $\mathrm{V}$ is the most frequent coagulation defect found in patients with cerebral venous thrombosis, with a prevalence similar to that found in patients with venous thromboembolism.

\section{REFERENCES}

1. Bertina LM, Koeleman RPC, Koster T, Rosendaal FR, Dirven RI, de Ronde H, wan der Velden PA, Raisma PH. Mutation in blood congulation factor $\mathrm{V}$ associated with tesistance ro activated protein $\mathrm{C}$. Nature 1994 ; 369 : $64-7$

2. Kalafatis $M$, Rand MD, Manm KG. The mechanism of inctivation of human factor $V$ and lumman lactot $V a$ by activated proten C. I Biol Chem $1994 ; 269 ; 3869-80$

3. Dahlback $B$. Inherited thrombophilia: resistance to activated protein $C$ as a pathogenic factor of venous thrombocmbolism. Blood 1995; $85: 607-14$

4. Buonano FS, Moody DM, Ball MR, Laster DW. Comptied cranal tomography lindings in cerbbal sinovenous Dechusion. J Comput Assist Tomogr 1978; 2: $281-90$

5. Frezato $M, T$ osetto A, Rodeghiero F. Validation of a questionnaire for the diagnosis of wenous whombuenbolisin. Br J Haematol $1994 ; 87(1): 79$

6. de Ronde H, Bertina RM. Laboratory diagnosis of APC-resistance: a critical ewaluation of the thst thind the dewelopment of diagnostic criteria. Thromb Haemost 1994; 72:880 6

7. Manuncei PM, Tripodi A. Laboratory screenung of inherited thrombophilic syndromes. Thromb Hacmosi 1987 ; $57: 247.51$

8. Feinstein DI. Lupus anticongulant, anticardiolipin antibodies, fetall loss and systemic lupus erythematosus Blood $1992 ; 80: 859-62$

9. Enevoldson TP, Ross Russel RW. Cerebral wenous thrombosis: new causes for an old syndrome? Quart 1 Med $1900: 77: 1255-75$

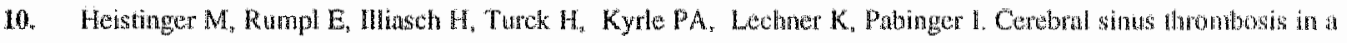

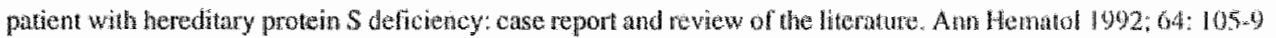

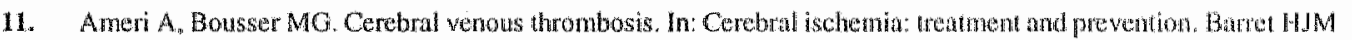
and Machinsk UC, eds. Neurol Clin 1992:10:87.111

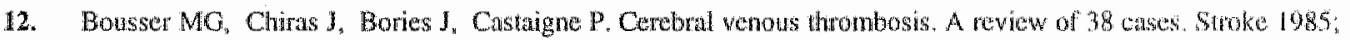
$16.199-213$

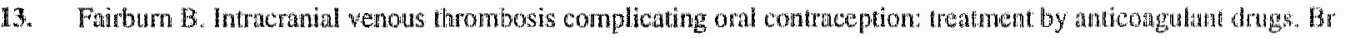
Med J $1973 ; 2: 647$

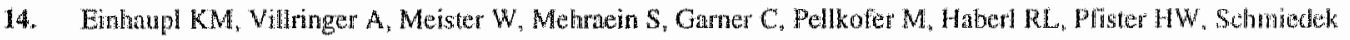
P. Heparin treatment in sinus verous thrombosis. Lancet $1991 ; 338 ; 597.600$ 


\section{ORAL CONTRACEPTIVES ARE A RISK FACTOR FOR CEREBRAL VEIN THROMBOSIS}

'Tda Martinelli, ${ }^{2}$ Fritz R. Rosendaal, ${ }^{2} J a n$ P.Vandenbroucke, ${ }^{\text {}}$ Pier Mannuccio Manmucci

"A. Bianchi Bonomi" Hemophilia and Thrombosis Center, Institute of Internal Medicine, IRCCS Ospedale Maggiore, University of Milan, Italy and ${ }^{2}$ Dpt of Clinical Epidemiology, Leiden University Hospital, Leiden, The Netherlands

Thromb Haemost 1996; 74:477-8 
In their study on the association between the factor V Leiden mutation and cerebral vein thrombosis Martinelli et al (1) found that oral contraceptive intake was the most frequent circumstantial risk factor present at the time of the episode. However, the relative risk for oral contraceptives was underestimated as being 2.1, and was not statistically significant. Women who were pregnant or in the post-partum period should not have been considered in the statistical analysis, because oral contraceptives and pregnancy mutually exclude each other. Upon re-analysis of the data after exclusion of one pregnant and three post-partum women and their matched controls, oral contraceptive users were 12/16 (75\%) among patients with cerebral vein thrombosis and 20/48 (42\%) among controls, with an odds ratio of 4.2 (95\% confidence interval: $1.2-14.9, p=0.04$ ). Adjustment for age did not affect the odds ratio. The magnitude of this relative risk in oral contraceptive users is very similar to that found by Vandenbroucke et al (2) for deep vein thrombosis of the lower limbs. Vandenbroucke et al (2) also looked at the synergism between oral contriceptives and the factor V Leiden mutation, finding that oral contraceptive users who carry the mutation have a risk of thrombosis more than 30-fold higher than that of women who did not use oral contraceptives and were non-carriers. No information on such gene-environment interaction in cerebral vein thrombosis can be drawn from the study of Martinelli et al (1), because the number of cases analysable is too small. Further studies on larger series of patients with cerebral vein thrombosis are needed to establish whether an interaction exists and to calculate the magnitude of the thrombotic risk derived by the synergism of the two predisposing conditions. This may have important implications for the assessment of the benefits of large-scale screening for factor $V$ Leiden mutation in women starting oral contraceptives, a screening that at the moment is not advisable (3).

\section{REFERENCES}

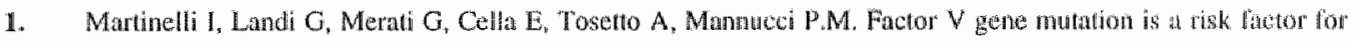
cerebral wein thombosis. Thromb Hacmost 1996;75:393-4

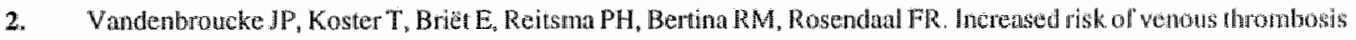
in oral-contraceptive users who are carrers of factor V Leiden meltation. Lancet 1994-344:145.7-7

3. Rosendad FR. Oral contraceptives and screening for facton $V$ Leiden. Thromb Haemost 1996;75:524-5 


\section{RISK FACTORS IN PRIMARY DEEP VEIN THROMBOSIS OF THE UPPER LIMBS}

Ida Martinelli, Marco Cattaneo, Daniela Panzeri, Emanuela Taioli*', Pier Mannuccio Mannucci

"A. Bianchi Bonomi" Hemophilia and Thrombosis Center, Institute of Internal Medicine and *Epidemiology Unit, IRCCS Ospedale Maggiore, Univessity of Milan, Italy.

Ann Intern Med 1997;126;707-11

Financial support: this study was supported by institutional founds provided by the IRCCS Maggiore Hospital and Angelo Bianchi Bonomi Foundation. 


\section{SUMMARY}

Background. Hypercoagulable states and circumstantial risk factors (surgery, trauma, immobilization, oral contraceptives and pregnancy), are associated with an increased risk for deep vein thrombosis (DVT) of the lower limbs.

Objective. To evaluate the prevalence of these factors in patients with primary DVT of the upper limbs, i.e. not associated with catheterization, mediastinal tumors, congestive heart failure, infection, drug abuse or clavicular fracture.

Patients and methods. Thirty-six consecutive patients with primary upper limb DVT, 121 age- and sex-matched patients with DVT of the lower limbs and 108 age- and sex-matched healthy controls were investigated for hypercoagulable states due to abnormalities of the natural anticoagulant system (resistance to activated protein $\mathrm{C}$, deficiency of antithrombin, protein $\mathrm{C}$ or protein $\mathrm{S}$ ), antiphospholipid antibodies and hyperhomocysteinemia. The association of thrombotic episodes with circumstantial risk factors was also evaluated.

Results. The prevalence of abnormalities of the natural anticoagulant system in patients with upper limb DVT (9\%) was similar to that of controls $(6 \%)$ and significantly lower than in patients with lower limb DVT $(31 \%)$. Hyperhomocysteinemia was diagnosed in $6 \%$ of patients with upper limb DVT, in $7 \%$ of controls and in $14 \%$ of patients with lower limb DVT. Antiphospholipid antibodies were found only in patients with DVT of the lower limbs (7\%). The overall prevalence of hypercoagulable states in patients with upper limb DVT $(15 \%)$ was similar to that found in healthy controls $(12 \%)$ but was significantly lower than in patients with lower limb DVT $(56 \%)$. The frequency of oral contraceptive users and pregnancy/puerperium in women with upper limb DVT (19\% and zero) was similar to that in controls ( $30 \%$ and zero), but lower than that in lower limb DVT women $(53 \%$ and $19 \%)$. A recent history of strenuous muscular exercise of the affected limbs was the most frequent circumstantial risk factor for upper limb DVT $(33 \%)$.

Conclusions. The prevalence of inherited and acquired hypercoagulable states is not increased in patients with primary upper limb DVT.

\section{INTRODUCTION}

Deep vein thrombosis (DVT) of the upper limbs accounts for 4 to $13 \%$ of all DVTs $(1,2)$. In approximately $75 \%$ of cases, upper limb DVT is secondary to the insertion of indwelling subclavian catheters, mediastinal tumors, heart failure, infection, drug abuse, clavicular fracture or dislocation (3). The remaining $25 \%$ of cases are usually referred to as primary DVT, since no obvious predisposing or triggering factor can be recognized $(4,5)$. 
Hypercoagulability and stasis are the most important pathogenic mechanisms of DVT of the lower limbs (6). Hypercoagulable states determined by inherited abnormalities of the natural anticoagulant systems [resistance to activated protein $\mathrm{C}$ (APC) and deficiencies of antithrombin, protein $\mathrm{C}$ or protein $\mathrm{S}$ ], antiphospholipid antibodies or hyperhomocysteinemia are associated with an increased risk of developing DVT of the lower limbs (7). The thrombotic risk in patients with lower limb DVT is also increased by the presence of circumstantial risk factors (such as surgery, trauma, immobilization, pregnancy or puerperium and oral contraceptive intake), which act by activating the coagulation system and causing venous stasis. In contrast, little or no information is currently available about the association between upper limb DVT and hypercoagulable states or circumstantial risk factors for thrombosis. The primary goal of this study was to evaluate the prevalence of these factors in patients with primary upper limb DVT as compared to patients with DVT of the lower limbs and to healthy individuals.

\section{PATIENTS AND METHODS}

\section{Patients with upper limb deep vein thrombosis}

Forty-nine consecutive unrelated patients who had developed a first episode of upper limb DVT were referred to the Thrombosis Center between January 1993 and January 1996 to be examined for the existence of a hypercoagulable state. None of the patients had liver or renal disease, congestive heart failure, myeloproliferative disease, infection, history of drug abuse or clavicular fracture. Thirteen patients with a potential cause of DVT" (2 with bulky lymphoma, one with lung cancer, 3 with autoimmune disease, 6 with thrombosis secondary to catheterization and one with a previous DVT of the lower limbs) were not accepted for the study. Therefore, 36 patients with primary upper limbs DVT ( 15 men and 21 women, median age 28 years, range $18-56$ years) were investigated. Table 1 describes sex, age at the time of thrombosis, location and side of the thrombus. In all patients, at least 2 months had elapsed from the occurrence of the acute thrombotic episode to enrolment. Anticoagulant therapy had been interrupted at least one month before blood sampling in 34 patients, while it was still ongoing in 2. The diagnosis of thrombosis had been confirmed by duplex scanning in 19 patients and by contrast venography in 17. Thrombosis involved the axillary and/or subclavian veins in 34 patients, and the brachial vein in 2 ; in $61 \%$ of the cases thrombosis was located in the right arm (Table 1). No patient had had clinical symptoms suggestive of pulmonary embolism. 
Table 1. General characteristics of patients with deep wein thrombosis of the upper fimbs and circumstantial risk factors at the time of thrombosis

\begin{tabular}{|c|c|c|c|c|c|}
\hline$\#$ & $\operatorname{sex}$ & $\begin{array}{l}\text { age at the time } \\
\text { of thrombosis }\end{array}$ & $\begin{array}{l}\text { thrombus } \\
\text { location }\end{array}$ & side & $\begin{array}{c}\text { circumastantial } \\
\text { trisk factor }\end{array}$ \\
\hline 1 & M & 53 & axillary/subclavian & right & none \\
\hline 2 & M & 19 & subclavian & left & none: \\
\hline 3 & $F$ & 34 & stubclavian & left & none \\
\hline 4 & F & 35 & axillary/subclavian & right & oral contracepinds \\
\hline 5 & $\mathrm{~F}$ & 40 & brachial & right & none \\
\hline 6 & $M$ & 18 & brachial & right & none \\
\hline 7 & $\mathbb{F}$ & 20 & axillary/subclavian & right & none \\
\hline 8 & $M$ & 21 & axillary & left & boxing \\
\hline 9 & M & 22 & axillary/subclavian & right & weight lifting \\
\hline 10 & $\mathrm{M}$ & 21 & axillary & left & trauma \\
\hline 11 & $F$ & 24 & subclavian & laft & none \\
\hline 12 & $\sqrt{F}$ & 25 & axillary/subclavian & right & oral contraceptive \\
\hline 13 & M & 26 & axillary/subclavian & left & weight lifting \\
\hline 14. & M & 23 & axillary & left & none \\
\hline 15 & $\mathrm{~F}$ & 28 & axillary/subclavian & right & none \\
\hline 16 & $\mathrm{~F}$ & 28 & subclavian & right & none \\
\hline 17 & M & 29 & axillary/subclavian & right & weight lifting \\
\hline 18 & M & 30 & axillary/subclavian & left & none \\
\hline 19 & $\mathrm{~F}$ & 31 & axillary/subclavian & right & oral contraceptive \\
\hline 20 & M & 31 & axillary & right & weight lifting \\
\hline 21 & $\mathrm{~F}$ & 27 & axillary & left & oral contraceptive \\
\hline 22 & $\mathrm{~F}$ & 37 & axillary & right & none \\
\hline 23 & $\mathrm{~F}$ & 43 & axillary & left & weight lifing \\
\hline 24 & M & 43 & axillary & left & none \\
\hline 25 & $F$ & 31 & axillary & left & none \\
\hline 26 & M & 46 & axillary/subclavian & right & none \\
\hline 27 & $\overrightarrow{\mathbb{F}}$ & 19 & axillary/subclavian & thght & none \\
\hline 28 & $\mathbb{F}$ & 25 & subclavian & left & trauma \\
\hline 29 & $F$ & 47 & subclavian & right & none \\
\hline 30 & $\mathrm{M}$ & 22 & subclavian & right & none \\
\hline 31 & $F$ & 19 & axillary & right & none \\
\hline 32 & $\mathrm{~F}$ & 38 & axillary & right & none \\
\hline 33 & F & 20 & axillary & right & surgery \\
\hline 34 & $\mathrm{~F}$ & 18 & axillary/subclavian & left & none \\
\hline 35 & M & 56 & axillary/subclavian & right & inmobilization \\
\hline 36 & $F$ & 32 & axillary/subclavian & right & none \\
\hline
\end{tabular}




\section{Patients with lower limb deep vein thrombosis}

From January 1993 to January 1996, 162 patients with a first episode of DVT of the lower limbs were referred to our Center to be examined for the existence of a hypercoagulable state. One-hundred and twenty-one of them ( 48 men and 73 women, median age 31 years, range 15-61 years) were retrospectively included in this study as they matched by age, sex ( \pm 5 years), geographic origin and social status the patients with upper extremity DVT, and had no evidence of overt neoplastic, autoimmune, liver or renal disease. For all patients the diagnosis of DVT had been confirmed by ultrasonography or contrast venography. Twenty of them were on oral anticoagulant therapy at the time of blood sampling.

Any of the circumstantial risk factors that are known to be associated with an increased risk for DVT of the lower limbs (such as surgery, trauma, immobilization, pregnancy or puerperium and oral contraceptive intake) were recorded for all patients. In addition, the association of thrombotic episodes with strenuous muscular activity of the affected limbs was evaluated, since it is considered a pathogenic factor for upper limb DVT $(8,9)$.

\section{Controls}

One-hundred and eight healthy individuals (45 men and 63 women, median age 31 years, range 19-58 years) matched for age, sex ( \pm 5 years), geographic origin and social status with patients with upper limb DVT were enrolled as controls. They were friends or partners of patients referred to our Center for thrombotic episodes. Previous accurrence of thrombosis was excluded for all controls by a structured questionnaire validated for retrospective diagnosis of thrombosis (10).

\section{Laboratory tests}

Blood samples were drawn into vacuum tubes containing $3.8 \%$ sodium citrate (for clotting assays) or EDTA (for homocysteine measurements) as anticoagulants, or no anticoagulant (for anticardiolipin antibodies).

Resistance to APC was assayed by an APTT-based clotting method (11) and, when abnormal or borderline results were obtained, DNA analysis for 1691GA substitution in coagulation factor $V$ gene was carried out (12). Antithrombin was measured by a commercially available functional assay (Coamate Antithrombin, Chromogenix AB, Mölndal, Sweden) as anti-Xa activity in the presence of heparin. Protein $C$ was measured by a functional clotting assay (IL Test ProClot, Instrumentation Laboratory, Milano, Italy) after activation by a snake venom (Protac $(B)$ ). Total and free protein $S$ were measured by ELISA with polyclonal anti-protein $S$ antibodies (11). Free protein $S$ was separated 
from that bound to $\mathrm{C} 4 \mathrm{~b}$-binding protein after precipitation of sample plasma with polyethyleneglycol 6000 (3.5\% final concentration).

Antiphospholipid antibodies were diagnosed when lupus anticoagulant and/or anticardiolipin antibodies were present. The lupus anticoagulant was diagnosed according to the criteria issued by the Scientific and Standardisation Committee (SSC) of the International Society on Thrombosis and Haemostasis (13), and the presence of anticardiolipin antibodies was defined when IgG titer was above 10 units, confirmed at least once after eight weeks (14).

Total plasma homocysteine levels were measured by high performance liquid chromatography and electrochemical detection (15) after an overnight fast and 4 hours after a methionine load $\left(3.8 \mathrm{~g} / \mathrm{m}^{2}\right.$ body surface area). Hyperhomocysteinemia was diagnosed when fasting plasma homocysteine levels or post-methionine-load absolute increments above fasting levels exceeded the 95th percentile of distribution values in healthy controls. Since nutritional deficiencies can cause high plasma homocysteine levels (16), serum vitamin $B_{\Downarrow 2}$ and folate levels were measured by radioimmunoassay Diagnostic Products Corporation (Los Angeles, CA).

Plasma homocysteine levels were not measured in four patients with DVT of the lower limbs. Two patients with upper limb DVT and 20 with lower limb DVT were tested only for antithrombin, plasma homocysteine, antiphospholipid antibodies and factor V mutation, since oral anticoagulant treatment at the time of blood sampling made accurate measurement of vitamin $\mathrm{K}$-dependent protein $\mathrm{C}$, protein $\mathrm{S}$ and $\mathrm{APC}$ resistance not reliable.

\section{Statistics}

To compare the prevalences of coagulation abnormalities, hyperhomocysteinemia and circumstantial risk factors predisposing to thrombosis in patients and controls, Fisher's exact test was used. To compare the age at the time of thrombosis for patients with upper and lower limb DVT, the Student t-test was used. Since oral contraceptives and pregnancy mutually exclude each other, the frequency of oral contraceptive users was calculated after exclusion of pregnant women and the frequency of pregnancy after exclusion of oral contraceptive users. Crude odds ratios (OR) and $95 \%$ confidence intervals (CI) with the approximation of Woolf (17) were calculated as a measure of the association between each risk factor and DVT of the lower or upper limbs.

\section{RESULTS}

In patients with upper limb DVT, the prevalence of abnormalities of the natural 
anticoagulant systems (deficiencies of antithrombin, protein $\mathrm{C}$ or protein $\mathrm{S}$, and APC resistance) $(9 \%)$ was similar to that found in controls $(6 \%$, OR $1.7,95 \% \mathrm{Cl} 0.4-7.0)$ but significantly lower than in patients with DVT of the lower limbs $(31 \%, \mathrm{OR} 0.2,95 \% \mathrm{CI}$ $0.1-0.8$ ) (Table 2).

Table 2. Prevalence of coagulation abnomalities and thyperhomocysteinemia in patients with deep wein thiombosis of the upper or of the lower limbse and in healthy controls

\begin{tabular}{|c|c|c|c|c|c|c|}
\hline \multirow{3}{*}{ type of coagulation abowomality } & \multicolumn{3}{|c|}{ number abnormal/number teised (\%) } & \multirow{2}{*}{\multicolumn{3}{|c|}{$\begin{array}{l}\text { Oddg Ratio } \\
\text { (95) CD }\end{array}$}} \\
\hline & \multirow{2}{*}{$\begin{array}{c}\text { avper lirib } \\
\text { (a) }\end{array}$} & \multirow{2}{*}{$\begin{array}{c}\text { lower llimb } \\
\text { DVY, } \\
\text { (b) }\end{array}$} & \multirow{2}{*}{$\begin{array}{l}\text { healthy } \\
\text { controls } \\
\text { (c) }\end{array}$} & & & \\
\hline & & & & $a v s b$ & 和 & b 坚琶 \\
\hline $\begin{array}{l}\text { resistance to } \\
\text { activated protain } \mathrm{C}\end{array}$ & $3 / 36(8)$ & $22 / 121(18)$ & $3 / 108(1)$ & & & \\
\hline andthrombin deficiency & $0 / 36$ & $3 / 12 \|(3)$ & $0 / 108$ & $0.2(0.4-0.8)$ & $1.7(0.47 .0)$ & $7.5(3.0-19.0)$ \\
\hline protein C deficiency & $0 / 3.4$ & $4 / 101(4)$ & $18108(1)$ & & & \\
\hline protein $S$ deficiency & $0 / 3,4$ & $2 / 10 \|(2)$ & $2108(2)$ & & & \\
\hline antiphospholipid matibodies & $0 / 36$ & $8 / 121(7)$ & $0 / 108$ & NA & NA & NA \\
\hline byperlinomocysteinemia. & $2 / 36(6)$ & $16 / 117(14)$ & $78108(7)$ & $0.4(0.1-1.7)$ & $0.8(0.2-4.3)$ & $2.3(0.9-5.8)$ \\
\hline all abromalinies & $5 / 34(15)$ & $55 / 98(56)$ & $13 / 108(12)$ & $0.1(0.1-0.4)$ & $1.3(0.4-9.8)$ & $9.3(4.6-18.9)$ \\
\hline
\end{tabular}

$\mathrm{NA}=$ not avallable

In contrast, the prevalence of these abnormalities was higher in patients with DVT of the lower limbs than in controls (OR 7.5, 95\% CI 3.0-19.0). Of the 25 patients ( 3 upper limb and 22 lower limb DVT) and 3 controls who had abnormal results in the APC resistance test, 24 were heterozygotes for the $1691 \mathrm{GA}$ substitution in the factor $\mathrm{V}$ gene, and one with lower limb DVT was a homozygote. The prevalence of hyperhomocysteinemia, similar in patients with upper limb DVT $(6 \%)$ and controls $(7 \%$, OR $0.8,95 \%$ CI $0.2-4.3)$, seemed to be higher in patients with DVT of the lower limbs (14\%) than in controls, but the difference was not statistically significant (OR 2.3, 95\% CI 0.9-5.8) (Table 2). Three patients with lower limb DVT and two controls had hyperhomocysteinemia and low serum vitamin $B_{12}$ and/or folate concentrations (not shown). Antiphospholipid antibodies were found in 8 patients (7\%) with DVT of the lower limbs only.

The overall prevalence of the abnormalities was calculated for those subjects who underwent a complete laboratory screening (108 controls, 34 patients with upper limb DVT and 98 with lower limb DVT). This prevalence was similar in patients with upper limb DVT to that found in controls $(15 \%$ ys $12 \%$, OR $1.3,95 \%$ Cl $0.4-3.8)$ but much lower than in patients with DVT of the lower limbs (15\% vs $56 \%$, OR $0.1,95 \%$ CI $0.1-0.4)$, in whom it was much higher than in healthy controls ( $56 \%$ vs $12 \%$, OR 9.3, 95\% CI 4.6-18.9).

The overall frequency of the association between thrombotic episodes and circumstantial risk factors for thrombosis was significantly higher in patients with lower limb DVT (69\%) than in those with upper limb DVT (39\%, $\mathrm{p}=0.002$ ) (Table 3). 
Table 3. Comparison of the frequencies of circumstantial ask factors at the time of thrombosis in up. per or lower limb deep vein thrombosis

\begin{tabular}{|c|c|c|c|}
\hline & $\begin{array}{l}\text { upper limb } \\
\text { DVT }\end{array}$ & $\begin{array}{l}\text { lower limb } \\
\text { DVT }\end{array}$ & pwahe \\
\hline number (men/women) & $36(15 / 21)$ & $121(48 / 73)$ & 0.9 \\
\hline $\begin{array}{l}\text { median age (years) at the time } \\
\text { of thrombosis (range) }\end{array}$ & $28(18-56)$ & $31(15-61)$ & 0.1 \\
\hline $\begin{array}{l}\text { overall prevalence of } \\
\text { circumstantial risk factors }(\%)\end{array}$ & $14 / 36(39)$ & $83 / 121(69)$ & 0,002 \\
\hline $\begin{array}{l}\text { - in men } \\
\text { strenuous muscular }\end{array}$ & $7 / 15(47)$ & $25 / 48(52)$ & 0.8 \\
\hline $\begin{array}{l}\text { activity of the involved limbs } \\
\text { surgery } \\
\text { traumalimmobilization }\end{array}$ & $\begin{array}{l}5 / 15(33) \\
0 \\
2 / 15(13)\end{array}$ & $\begin{array}{l}4 / 48(8) \\
8 / 48(17) \\
13 / 48(27)\end{array}$ & $\begin{array}{c}0.03 \\
0.5\end{array}$ \\
\hline $\begin{array}{l}\text { - in women } \\
\text { strenuous muscular activity }\end{array}$ & $7 / 21(33)$ & $58 / 73(79)$ & 0.0001 \\
\hline of the involved limbs & $1 / 21(5)$ & $2 / 73(3)$ & 0.5 \\
\hline surgery & $1 / 2 \mid(5)$ & $8 / 73(11)$ & 0.7 \\
\hline trauma/immobilization & $1 / 21(5)$ & $3 / 73(4)$ & 1.0 \\
\hline oral contraceptiwes & $4 / 21(19)$ & $31 / 59(53)$ & 0.01 \\
\hline pregnancy/puerperium & 0 & $14 / 42(33)$ & - \\
\hline
\end{tabular}

This difference was limited to women and was attributable to oral contraceptive use (53\% among women with lower limb DVT and $19 \%$ among those with upper limb DVT, $\mathrm{p}=0.01$ ), and to pregnancy or puerperium ( $33 \%$ of women with lower limb DVT and zero with upper limb DVT). $30 \%$ of the control women were taking oral contraceptives and none was pregnant or in the post-partum period. Table 4 shows that the frequency of oral contraceptive users was not significantly different in women with upper limb DVT and controls ( $19 \%$ and $30 \%$ ), both being significantly lower than that in women with lower limb DVT (53\%).

In men, the overall prevalence of circumstantial risk factors was similar for patients with upper and lower limb DVT (47\% and 52\%) (Table 3). However, the risk factors

Table 4. Prevalence of oral contraceptive users and relative risk for thrombosis associated with oral contraceptives in women with deep vein thrombosis of the upper limbs $(n=19)$, of the lower limbs $(n=59)$ and in controls $(n=63)$

\begin{tabular}{lcc}
\hline & prevalence $(\%)$ & OR $(95 \%$ CI $)$ \\
\hline upper limb DVT ys controls & 19 ws 30 & $0.5(0.2-1.8)$ \\
upper limb DVT ys lower limb DVT & 19 ws 53 & $0.2(0.1-0.7)$ \\
lower limb DVT ys controls & 53 ys 30 & $2.6(1.2-5.4)$ \\
\hline
\end{tabular}


differed in the two groups. While men with lower limb DVT had been exposed relativelly frequently to surgery and trauma or immobilization (17\% and $27 \%$ ys zero and $13 \%$ in upper limb DVT), the most prevalent predisposing factor in men with upper limb DVT was strenuous muscular activity (boxing or weight lifting), contrasting with men with lower limb DVT (mountain biking or soccer) $(33 \%$ vs $8 \%, \mathrm{p}=0.03)$.

\section{DISCUSSION}

The pathogenesis of thrombosis involves the combination of hypercoagulability, vascular damage and stasis (18). While vascular damage plays a major role in arterial thrombosis, hypercoagulability and stasis are considered to be the principal mechanisms involved in venous thromboembolism $(6,7)$. Hypercoagulability may be due to acquired conditions (neoplastic, myeloproliferative or autoimmune diseases) or to inherited deficiencies of the proteins involved in the natural anticoagulant system (antithrombin, protein $C$ and protein $S$ ). Recently, it has been recognized that two novel hypercoagulable states are associated with an increased risk of venous thromboembolism, one is resistance to activated protein $\mathrm{C}$ caused by $1691 \mathrm{G} \rightarrow \mathrm{A}$ substitution in the gene coding for coagulation factor $\mathrm{V}(19,20)$ and the other is hyperhomocysteinemia, a metabolic defect involving the methionine-cystationine pathway (21-23). Thrombotic risk is also enhanced by the presence of circumstantial risk factors, such as surgery, trauma, pregnancy and oral contraceptives, which may cause acquired hypercoagulable states and/or cause stasis.

In this study we have demonstrated that a hypercoagulable state due to abnormalities of the anticoagulant system or of methionine metabolism is not frequent in patients with primary upper limb DVT. In contrast, the prevallence of these abnormalities was high in a group of patients witl DVT of the lower limbs, who were comparable to the patients with upper limb DVT for age, sex, period of referral to the Thrombosis Center and selection criteria. All the patients in the study had had a first documented episode of DVT of the upper or of the lower limbs and had been referred to our Center to be investigated for the presence of a hypercoagulable state.

Another important difference was that the frequency of the association between thrombotic episodes and conditions that temporarily cause hypercoagulability, such as oral contraceptives and pregnancy or puerperium, was increased only in women with DVT of the lower limbs. The frequency of the association of DVT with circumstantial risk factors was similar in men with upper or lower limb DVT. However, whereas the most common factors associated with DVT of the lower limbs were surgery, trauma or immobilization, conditions that cause hypercoagulability and venous stasis, in men with upper limb DVT the most frequent risk factor was strenuous muscular activity of the upper limbs. This risk factor was found infrequently in women. 
These data suggest that the pathogenesis of DVT of the upper limbs differs from that of DVT of the lower limbs (6), and that mechanisms other than a procoagulant imbalance prevail. Hemodynamic factors and vascular damage are likely to play a major role. The relative rarity of upper limb DVT is probably due to the fact that, unlike the lower limbs, the upper limbs lack valve pockets, which represent an area of maximum stasis, and to the fact that blood flow is not opposed by high hydrostatic forces. As a consequence, local accumulation of activated coagulation factors and fibrin deposition are less likely to occur. However, in individuals with predisposing anatomical abnormalities, such as thoracic outlet compression or anomalous musculofascial bands, which are often unappreciated and difficult to diagnose, strenuous muscular activity may aggravate the intrinsic compression of the veins. This could cause endothelial damage, fibrosis around the vein and reduction of the blood flow, contributing to the formation of thrombi.

In conclusion, this is the first study showing that the development of thrombi in the veins of the upper limbs is not associated with permanent or transient conditions causing a hypercoagulable state. Therefore, unlike patients with lower limb DVT, patients with primary upper limb DVT do not need to be investigated for congenital or acquired abnormalities which cause hypercoagulability, but a recent history of strenuous muscular activity of the involved limbs must be looked for. A surgical approach for prevention of recurrences is recommended by some authors $(3,8,9)$, but no proof of its efficacy exists. Since hypercoagulability is relatively rare in patients with upper limb DVT, the value of long-term anticoagulant therapy is doubtful, while an early treatment with heparin or thrombolytic agents (24) is thought to be effective in reducing the complications of pulmonary embolism $(25,26)$ and postphlebitic syndrome $(26)$.

Acknowledgements. This work was supported in part by institutional grants from IRCCS Maggiore Hospital and Angelo Bianchi Bonomi Foundation. We thank Drs A.Tripodi and E.M.Faioni who supervised the laboratory tests used in this study.

\section{REFERENCES}

1. Rochester IR, Beard JD. Acute management of subclavian vein thrombosis. Bt J Surg 1995:82:433-4.

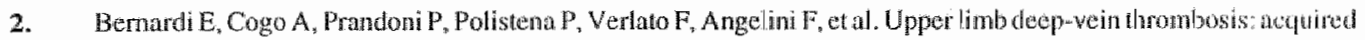

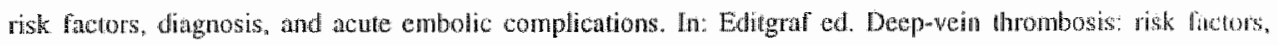
diagnosis, and climical course, A.Cogo, PhD Thesis. Padowa 1995:191-206.

3. Horatlas MC, Wright DJ, Fenton AH. Evans DM, Oddi MA, Kamienski RW, et al. Changing oncepts of deep venous thrombosis of the upper extremity. Report of a series and review of ahe literature. Surgery $1988 ; 104: 561-7$.

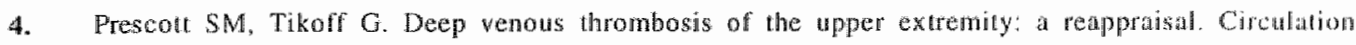
$1979 \cdot 59 \cdot 350-5$

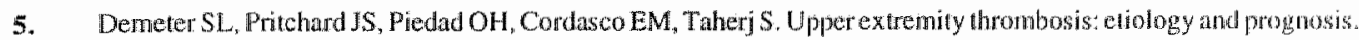


Angiology 1982; November: 743-8.

6. Thomas D. Pathogenesis of venous thrombosis. In: Bloom AL, Forbes CD, Thomas DP, Tudidenham EGD, eds. Haenostasis and Thrombosis. Third edition. Churehill Livingstone; 1994:1335-47.

7. De Stefano V. Finazzi G, Mannucci PM. Inherited thrombophilia: pathogenesis, clinical syndrones, and management. Plood $1996,873531-44$.

8. Azix S, Strathley CJ, Whelan TI. Effort-related axillosubclavian vein thrombosis. A new theory of pathogenesis and a plea for direct surgical intervention. Am J Surg 1986: 152:57-60.

9. Donayre CE, White GH, Mehringer SM, Wilson SE. Pathogenesis determines late morbidity of axillosubclavian vein thrombosis. Am J Surg 1986;152:179-84

10. Frezzato $M$, Tosetto $A$, Rodeghiero $F$. Validation of a questionnaire for the diagnosis of venous thrombormbolism. Br J Haenatol 1994;87:79.

11. Faioni EM, Franchi F, Asti D, Sacchi E, Bernardi F, Mannucci PM. Resistance to activated protein $C$ in mine thrombophilic farnilies: interference with a protein S assay. Thromb Haemost 1993;70:1067-71.

12. de Ronde $H$. Bertina RM. Laboratory diagnosits of APC-resistance: a critical evaluation of the test and the development of diagnostic criteria. Thromb Haemost 1994; $72: 880-6$.

13. Brandt JT, Triplett DA, Alving $B$, Scharrer 1 . Criteria for the diagnosis of lupus anticongulants: an update. Thromb Hatmost 1995;74:1185-90.

14. Triplent DA. Antiphospholipid-protein antibodies: laboratory detection and clinical relevance. Thromb Res $1995 \div 78: 1-31$.

15. Malinow MR, Kang SS, Tay lor LM, Wong PWK, Coull B, Inahara T, et al. Prewalence of hyperhomocyst(e)inemia in patients with peripheral arterial occlusiwe disease. Circulation 1989:79:1180-8.

16. Malinow MR. Homocyst(e)ine and arterial occlusive disease. J Int Med 1994;236:60\%-17.

17. Woolf $B$. On estimating the relation between blood group and disease. Ann Hum Gen $₫ 955,19: 251-3$.

18. Virchow R. Cellular pathology, Joln Churchill, London, 1860.

19. Dafll bälck B. Inherited thrombophilia: resistance to activated protein $\mathrm{C}$ as a pathogenic factor of venous thromboembolism. Blood 1995;85:607-14.

20. Koster T, Rosendaal FR, de Ronde H, Briét E, Vandenbroucke JP, Bertina RM. Venous thrombosis due to poor anticoagulant response to activated protein $C$ : Leiden thrombophilia study. Lancet 1993;34:1503-6.

21. Falcon CR, Cattaneo M, Panzeri D, Martinelli I. Mannucei PM. High prevalence of hyperhonocyst(e)inemia in patients with juvenile venous thrombosis. Arterioscler Thromb 1994:14:1080-3.

22. den Heijer M, Koster T, Błom HJ, Bos GMJ, Brët E, Reitsma PH, et al. Hyperhomocystennemia as a risk factor for deep-vein thrombosis. N Engl J Med 1996;334:759-62.

23. den Heijer M, Blon HJ, Gerrits WBJ, Rosendaal FR, Haak HL, Wijermaus PW, et all Is hyperhomocysteinemia a risk facior lor recurrent venous thrombosis? Lancet 1995;345:882-5.

24. AlsuFthann AF, Sadter D, Stuart P, Khan MZ, Boland JP. Conventional versus thrombolytic therapy in spontaneous (effort) axillany subclavian vein thrombosis. Am J Surg 1991;161:459-65.

25. Monnenl M, Lalioz E, Ruiz J, Valls R, Alastrue A. Uppers extremity deep venous thrombosis and pulmonary embolism: a prospective study. Chest 1991;29:280-3.

26. Kor TM, Lutter KS, Modler DM, Hasselfeld KA, Roedersheimer LR, MeKenna PJ, et al. Upper extremity venous thrombosis diagnosed by duplex scanning. An J Surg 1990;160:202-6. 


\section{LOW PREVALENCE OF FACTOR V:Q506 IN PATIENTS WITH ISOLATED PULMONARY EMBOLISM}

Ida Martinelli, Marco Cattaneo, Daniela Panzeri, Pier Mannuccio Mannucci

"A. Bianchi Bonomi" Hemophilia and Thrombosis Center, Institute of Internal Medicine, IRCCS Ospedale Maggiore,

University of Milan, Italy

Thromb Haemost 1997;77:440-3 


\section{SUMMARY}

In 70-80\% of cases, pulmonary embolism is the consequence of deep vein thrombosis of the lower limbs. It has been stated that the most common coagulation defect predisposing to venous thrombosis, resistance to activated protein $\mathrm{C}(\mathrm{APC})$, is not associated with an increased risk for pulmonary embolism, but the opinion was based on a functional assay to diagnose A.PC resistance and no information about concomitant deep vein thrombosis was provided. The aim of our retrospective study was to evaluate the prevalence of factor $V: Q 506$, the gene mutation responsible for APC resistance, in patients with symptomatic non-fatal pulmonary embolism, whether or not associated with deep vein thrombosis. Patients with uncomplicated deep vein thrombosis and healthy controls were investigated as comparison groups. The overall prevalence of factor V:Q506 in 106 patients with pulmonary embolism was $12.3 \%$, lower than that found in 106 patients with deep vein thrombosis $(22.6 \%$, OR $0.5,95 \% \mathrm{CI} 0.2-1.0)$ but significantly higher than that found in 212 healthy subjects taken as controls $(2.8 \%$, OR $4.8,95 \% \mathrm{CI}$ 1.8-13.0). In the 41 patients with isolated pulmonary embolism, the prevalence was $4.9 \%$, similar to that in controls (OR $1.8,95 \% \mathrm{CI} 0.3-9.6)$, while in the remaining 65 patients with pulmonary embolism associated with deep vein thrombosis the prevalence was significantly higher (16.9\%, OR 5.5, 95\% CI. 2.0-15.8). In conclusion, the prevalence of factor V:Q506 in patients with isolated pulmonary embolism is similar to that found in the general population. This surprising finding needs confirmation by prospective studies.

\section{INTRODUCTION}

Hypercoagulability due to abnormalities of the coagulation system play an important role in the pathogenesis of venous thrombosis. The most common coagulation defect predisposing to venous thrombosis is resistance to activated protein $C$ (APC), due to a point mutation in the factor $\mathrm{V}$ gene that renders activated factor $\mathrm{V}$ less sensitive to inactivation by activated protein $C$, its naturally occurring inhibitor (1). Studies of patients with deep vein thrombosis have demonstrated 3.5- to 8-fold increased thrombotic risks in heterozygous carriers of factor V:Q506 (2-5).

It has been reported recently that APC resistance diagnosed by a functional assay was not associated with an increased risk for pulmonary embolism in an unselected population of patients suspected of pulmonary embolism and referred to an emergency ward (6). This finding was unexpected, because in the majority of cases pulmonary embolism occurs as a consequence of venous thrombosis (7), even though in $20-30 \%$ of cases no site of venous thrombosis can be identified (8).

Since functional assays of APC resistance have limited diagnostic sensitivity (9) and DNA analysis is currenttly the best way to diagnose APC resistance, we chose to evaluate 
the prevalence of factor $\mathrm{V}: \mathrm{Q} 506$ in patients who had symptomatic non-fatal pulmonary embolism, whether or not associated with deep vein thrombosis. Patients with deep vein thrombosis uncomplicated by pulmonary embolism and healthy subjects were also investigated in parallel.

\section{PATIENTS AND METHODS}

\section{Patients}

Two-hundred and fifty-two consecutive patients with a first episode of deep vein thrombosis and/or pulmonary embolism were consecutively referred to our Thrombosis Center between January 1993 and May 1996 for a coagulation screening. One-hundred and six patients (39 men and 67 women, median age 36 years, range 18-64 years) had symptomatic non-fatal pulmonary embolism, isolated in 41 of them ( 8 men and 33 women, median age 35 years, range 18-62 years), since no site of deep vein thrombosis could be detected by objective techniques, such as bilateral B-mode ultrasonography or duplex scanning (in 38 patients) and contrast venography (in 3 patients) of the lower limbs. None of these 41 patients reported symptoms of deep vein thrombosis (such as swelling or pain) or superficial thrombophlebitis. Isolated pulmonary embolisms were diagnosed by ventilation-perfusion lung-scan in 41 patients, bilateral in 17 ; in one patient who was pregnant at the time of the onset of symptoms, the diagnosis was made three months after delivery and confirmed the embolic episode. The patients with isolated pulmonary embolism were $16 \%(41 / 252)$ of all patients with venous thromboembolism referred to us during the study period. In the remaining 65 patients ( 31 men and 34 women, median age 38 years, range 20-64 years) who had pulmonary embolism associated with symptomatic deep vein thrombosis, pulmonary embolism was diagnosed by ventilationperfusion lung-scans in all and deep vein thrombosis by bilateral B-mode ultrasonography or duplex scanning for 49 , by contrast venography for 13 and by CT-scan for 3 .

The remaining 146 patients of our initial cohort had deep vein thrombosis of the lower limbs not complicated by symptomatic pulmonary embolism. From this group, 106 patients ( 39 men and 67 women, median age 34 years, range 15-66 years) matched by sex and age ( \pm 5 years) with those with pulmonary embolism were randomly chosen for this study. Diagnosis of deep vein thrombosis was made by bilateral B-mode ultrasonography or duplex scanning for 74, by contrast venography for 29 , and by CT-scan for 3 .

None of the patients included in the study had evidence of overt neoplastic, autoimmune, heart, liver or renal disease. Circumstantial risk factors known to be associated with increased venous thrombotic risk (such as recent surgery, trauma or immobilization, oral contraceptive intake, and pregnancy or puerperium) were recorded for all patients. 


\section{Healthy controls}

Two-hundred and twelve healthy subjects $(78$ men and 134 women, median age 39 years, range 16-67 years) matched by sex and age $( \pm 5$ years $)$ with patients with pulmonary embolism were the control population. They were from the same geographic area as patients referred to our Center for thrombotic episodes, and most were their friends or partners. The absence of previous thrombosis was established with a structured questionnaire validated for the retrospective diagnosis of thrombosis (10) and current oral contraceptive use was recorded.

\section{Laboratory test}

Blood samples were drawn into vacuum tubes containing $3.8 \%$ sodium citrate as anticoagulant, and DNA analysis for factor V:Q506 allele was performed by the PCR technique as previously described by de Ronde and Bertina (11).

\section{Statistics}

The prevalence of factor V:Q506 and circumstantial risk factors for patients with pulmonary embolism were compared to those for patients with deep vein thrombosis and healthy controls by Fisher's exact test. Crude odds ratios (OR) and $95 \%$ confidence intervals (CI) were calculated with the approximation of Woolf (12) as estimates of the relative risk for thrombosis in patients and controls. Adjustment for possible confounder factors, such as sex and age, was performed by the multiple logistic regression model. Age was categorized according to the median value of the controls ( 36 years).

\section{RESULTS}

The main characteristics of patients and controls and the presence of circumstantial risk factors at the time of thrombosis are listed in Table 1 . The prevalence of risk factors for thrombosis was not statistically significantly different between the patient groups. The most frequent risk factor was oral contraceptive intake, significantly higher in patients than in controls.

Overall, the factor $\mathrm{V}$ mutation was found in $13 / 106(12.3 \%)$ patients with pulmonary embolism, with or without deep vein thrombosis, in $24 / 106(22.6 \%)$ patients with uncomplicated deep vein thrombosis ( $\mathrm{OR} 0.5,95 \% \mathrm{Cl} 0.2-1.0)$ and in $6 / 212(2.8 \%)$ healthy individuals (OR 4.8,95\% CI 1.8-13) (Table 2). The prevalence of the mutation in patients with uncomplicated deep vein thrombosis was significantly higher than that found in healthy controls (OR 10.0, 95\% CI 4.0-25.5). 
Table 1. Main characteristics of patients and control population

\begin{tabular}{|c|c|c|c|c|c|}
\hline & $\begin{array}{l}\text { all puinnonary } \\
\text { embolism }\end{array}$ & $\begin{array}{c}\text { Isolated puhmonary } \\
\text { embolisin }\end{array}$ & $\begin{array}{c}\text { pulimonary embotism } \\
\text { phus deep velin } \\
\text { thrombosis }\end{array}$ & $\begin{array}{l}\text { uncontelicated } \\
\text { deep vein } \\
\text { drombosis. }\end{array}$ & 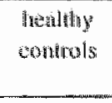 \\
\hline number & 106 & 41 & 65 & 106 & 212 \\
\hline manale/fernate & $39 \% 67$ & $8 / 33$ & 31134 & 39,67 & 7811,34 \\
\hline medisn age (rage) & $36(18-64)$ & $35(18-62)$ & $38(20-64)$ & $34(1.566)$ & $39(16-67)$ \\
\hline \multicolumn{6}{|l|}{ diagnostic examanutions (\%) } \\
\hline ventillation/perfusion lung-scan & $41(39)$ & $41(100)$ & $\approx$ & - & - \\
\hline $\begin{array}{l}\text { B-mode uftrasonography or } \\
\text { duplex scamning }\end{array}$ & $87(82)$ & $38(93)$ & $49(75)$ & 7400 & 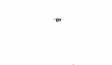 \\
\hline venography & $16(15)$ & $3(7)$ & $13(25)$ & $29(27)$ & $\therefore$ \\
\hline $\mathrm{CT}-\operatorname{scan}$ & $7(3)$ & - & $3(5)$ & $3(3)$ & - \\
\hline circumstantial risk factors (\%) & $78(74)$ & $34(83)$ & $44(68)$ & $71(67)$ & - \\
\hline sturgery & $20(19)$ & $8(20)$ & $12\{19\}$ & $10(9)$ & - \\
\hline duntivimmobilization & $16(15)$ & $3(7)$ & $1,3(20)$ & $13(12)$ & - \\
\hline oral contraceptives & $33(49)^{2 k}$ & $16(48)^{n}$ & $17(50)+$ & $34(64) \times$ & $38(28)$ \\
\hline pregnancy/puetper:̈й & $9(13)$ & $7(21)$ & $2(6)$ & $14(21)$ &. \\
\hline
\end{tabular}

$\mathrm{p}=0.003, \wedge_{\mathrm{p}}=0.04, \mathrm{~A} \mathrm{p}=0.02$ and $\mathrm{s} \mathrm{p}=0.002$ ys henlthy control women

Table 2. Association of factor V: Q506 with pulmonary embolism or with uncomplicated deep vein thrombosis

\begin{tabular}{lccc}
\hline & carriers/tested & \multicolumn{2}{c}{ OR $(95 \% \mathrm{CI}$} \\
\cline { 3 - 4 } & $13 / 106(12.3)$ & pulmonary embolisms & $\begin{array}{c}\text { uncomplicated } \\
\text { deep vein thrombosis }\end{array}$ \\
\hline $\begin{array}{l}\text { pulmonary embolisms } \\
\begin{array}{l}\text { uncomplicated deep } \\
\text { vein thrombosis }\end{array}\end{array}$ & $24 / 106(22.6)$ & $0.5(0.2-1.0)$ & - \\
healthy controls & $6 / 212(2.8)$ & $4.8(1.8-13.0)$ & $10(4.0)-25.5)$ \\
\hline
\end{tabular}

In patients with isolated pulmonary embolism, the prevalence of factor V:Q506 was $4.9 \%(2 / 41)$. This prevalence was not significantly different from that of controls $(2.8 \%$, OR $1.8,95 \%$ CI $0.3-9.6)$ and, although lower than in patients with pulmonary embolism associated with deep vein thrombosis $(16.9 \%$, OR $0.3,95 \% \mathrm{CI} 0.1-1.5)$, it was significantly lower than in patients with uncomplicated deep vein thrombosis $(22.6 \%$, OR 0.1 , 95\%Cl 0.03-0.7) (Table 3).

The prevalence of the factor $\mathrm{V}$ mutation in patients with pulmonary embolism associated with deep vein thrombosis was significantly higher than in healthy controls (OR 5.5,95\% CI 2.0-15.8) and similar to that in patients with uncomplicated deep vein thrombosis (OR 0.7, 95\%CI 0.3-1.7). Homozygosity for factor $\mathrm{V}: \mathrm{Q} 506$ was detected in 
Table 3. Prevalence of factor V:QS06 in patients with pulmonary embolism (PE) divided into those with isolated PE and PE associated with deep vein thrombosis (DVT), compared to patients with isolatted DVT and heal hy controls

\begin{tabular}{|c|c|c|c|c|c|}
\hline & \multirow[b]{2}{*}{$\begin{array}{l}\text { carried/tested } \\
(\%)\end{array}$} & \multicolumn{2}{|c|}{$\mathrm{OR}(95 \% \mathrm{Cl})$} & \multicolumn{2}{|c|}{$\mathrm{OR}^{*}(95 \% \mathrm{Cl})$} \\
\hline & & isolated PE & PE with DVT & isolated PE & PE with DVT \\
\hline isolated PE & $2 / 41(4,9)$ & - & - & - & . \\
\hline PE with DVT" & $11 / 65(16.9)$ & $0.3(0.1-1.2)$ & - & $0.3(0.1-1.5)$ & * \\
\hline $\begin{array}{l}\text { uncomplicated } \\
\text { DVT }\end{array}$ & $24 / 106(22.6)$ & $02 .(0.04-0.8)$ & 07. $(0.3-1.5)$ & $0.1(0.03-0.7)$ & $0.7(0.3-1.7)$ \\
\hline healthy controls & $6 / 212(2,8)$ & $1.8(0.3-9.0)$ & $7.0(2.5-19.8)$ & $1.8(0.3-9.6)$ & $5.5(2.0-15.8)$ \\
\hline
\end{tabular}

* data are adjusted by sex and age

three patients with uncomplicated deep vein thrombosis only. The statistical analysis did not substantially change after exclusion of the homozygous patients (not shown).

\section{DISCUSSION}

Pulmonary embolism and venous thrombosis are closely related diseases. Since pulmonary embolism occurs in the majority of cases as a consequence of cleep vein thrombosis (7), these clinically different diseases are usually considered to be a single entity of venous thromboembolism. Nevertheless, in $20-30 \%$ of patients with pulmonary embolism no site of deep vein thrombosis is detected $(7,8)$.

It has been reported recently that resistance to activated protein $C$, the most common coagulation defect predisposing to venous thrombosis, was not associated with an increased risk of pulmonary embolism in patients suspected of the disease and referred to an emergency unit (6). This surprising finding raised a question about the accuracy of the APTT-based test for the diagnosis of APC resistance. This issue has been discussed by Dahlbäck (9) who, referring to the aforementioned study, pointed out the limits of the functional assay for APC resistance. To overcome this problem, we looked at factor $\mathrm{V}:$ Q506 in patients with symptomatic pulmonary embolism diagnosed by objective methods, and found that its prevalence was significantly higher than in healthy subjects, but tended to be lower (nearly half) than in patients with deep vein thrombosis. These overall findings were in contrast with the study cited (6). However, when the subgroup of patients with isolated pulmonary embolism (i.e., with no recognized deep vein thrombosis) was analyzed, the prevalence of the factor $\mathrm{V}$ mutation was similar to that of healthy controls ( $4.9 \%$ vs $2.8 \%$ ), while in those with pulmonary embolism associated with deep vein thrombosis it was similar to that found of patients with uncomplicated deep vein thrombosis ( $16.9 \%$ vs $22.6 \%$ ). 
Our study has the limitation that we excluded deep vein thrombosis by B-mode ultrasonography or duplex scanning (venography was performed in only three patients with isolated pulmonary embolism). These diagnostic techniques are not sufficiently sensitive for asymptomatic patients and for patients with distal thrombosis $(13,14)$. On the other hand, the frequency of isolated pulmonary embolism in our series was similar to that previously found in patients who underwent pulmonary angiography and venography (8), and pulmonary embolism is associated with isolated calf vein thrombosis in fewer than $1 \%$ of cases $(15,16)$. Since the size of the venous thrombi is an important factor in producing local symptoms and emboli $(14,17)$, it is unlikely that large femoro-popliteal vein thrombi had gone undiagnosed and the corresponding patients were included among those with isolated pulmonary embolism. Perhaps isolated pulmonary emboli had originated from other venous sites, such as for instance the deep pelvic or hemorrhoidal veins or the deep femoral vein. An alternative explanation may be that pulmonary emboli originated from small thrombi in the femoro-popliteal veins that had detached completely, leaving no detectable residue in the deep veins.

The retrospective design of our study could have produced a selection bias due to the exclusion of patients who died from massive pulmonary embolism, and who may have carried the mutation. However, since the risk of embolization and the severity of pulmonary embolism are higher for proximal thrombi $(14,15)$, the prevalence of the mutation may have been underestimated only in the subgroup of patients with pulmonary embolism associated with deep vein thrombosis.

In conclusion, the results of this retrospective study suggest that the prevalence of factor V:Q506 responsible for APC resistance in patients with pulmonary embolism without a recognized site of deep vein thrombosis is low and similar to that found in the general population, whereas, confirming previous observations, it is high in patients with deep vein thrombosis, whether or not complicated by pulmonary embolism. Prospective studies of patients with isolated pulmonary embolism are needed.

\section{REFERENCES}

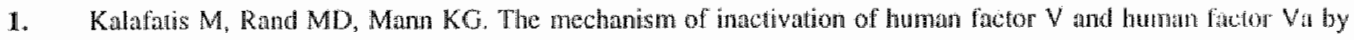
activated protein C. J Biol Chem 1994:269:3869-80

2. Bertina RM, Koeleman RPC, Koster T, Rosendaral FR, Dirven RI, de Ronde H, wan det Velden PA, Reitsnu PH. Mutation in blood coagulation factor $V$ associated with resistance to activated protein $C$ Nature 1994:369:64 7

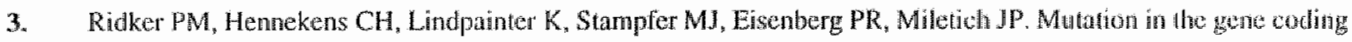
for coagulation factor $V$ and the risk of myocardial infarction, stroke, and wenows thrombosis in apparently heallhy men. N Engl I Med 1995;332:912-7

4. Dahlback $\mathrm{B}$. Inherited thrombophilia: resistance to acviwated proien $\mathrm{C}$ as a pathogenic factor of venous thromboenbolism. Blood 1995;85:607-14 
5. Vandenbroucke JP, Koster T, Brid E, Reismi PH, Bertina RM, Rosendal FR. Increased risk of wenous thrombosis in oralcontraceptive isers who are carriers of factor V Leiden mutation. Lancet 1994; 344:1453-7

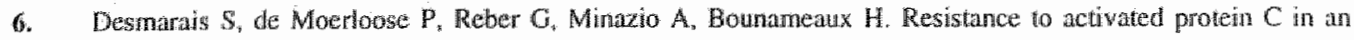
wriselected poptlation of patients with pulmonary embolism. Lancet $1996,347: 1374.5$

7. Hirsh J. Dugnosis of venous thrombos is and pumonary embolism. Am J Cardiol $1990 ; 65: 45 \mathrm{C}-49 \mathrm{C}$

8. Hull RO, Mirsh J Carter CJ Jay RM, Dadd PE, Ockelford PA, Coates G, Gill GI, Turpie AG, Doyle DI, Buller HR, Kuskob GE Pulmonary anglography, ventilation lang scamning, and venography for clinically stspected pulmonary mbolism with abnormal perfusion lung scan. Ann Intern Med 1983:98:891-99

9. Dahlbick B. Are we ready for factor V Leiden screening? Lancet 1996;347:1346-7

10. Frezzato $M$, Toseto $A$, Rodeghiero F. Valitation of a questionnaire for the diagnosis of venous thromboembolism. Br J Hacmatol 1994:87:79

11. de Ronde H, Bentina RM. Laboratory diagnosis of APC-resistance: a critical evaluation of the tesil and the development of dagnostic critteria. Thromb Haemost 1994;72,880-6

12. Woolf $\mathrm{B}$. On estimating the relation bewreen blood group and disease. Ann Hum Gen 1955:19:251-3

13. Habscheid W, Hoetman $M$, Withelm $T$, Epping $J$. Reallime ultrasound in the diagnosis of acute deep venous thrombosigs of the lower extremity. Angiology 1990;16:599-607

14. Moset KM, Lemoine JR, Is embolic risk conditioned by location of deep vein thrombosis? Ann Intern Med $1981 ; 94: 439-444$

15. Heijboer H, Brandjes DPM, Lensing A WA, Buller HR, ten Cate JW: Efficacy of real-time B-mode ultrisonography versus impedanoe plethysmogenphy in the diagnosis of deep vein thrombosis in symptomatic outapatienis. Thromb Hadrost 1991;65:804

16. Vacearo JP. Cronan JJ, Dorfman GS. Outione analysis of patients with normal compression US examination. Radiology 1900:175:645-649

17. Sevitt S, Gallagher $\mathbb{N}$. Venous thrombosis and pulmonary embolism. A clinico-pathological study in injured and burned patients. Br J Surg 1961;48:475-89 


\title{
Chapter 6
}

\section{Arg506GIn FACTOR V MUTATION AND CEREBRAL ISCHEMIA IN THE YOUNG}

\author{
'Gianluca Landi, ${ }^{1}$ Ermelinda Cella, ${ }^{2}$ Ida Martinelli, ${ }^{2}$ Liliana Tagliabue, \\ ${ }^{2}$ Pier Mannuccio Mannucci, ${ }^{3}$ David Zerbi
}

${ }^{1}$ Neurological Clinic and ${ }^{2 " A}$. Bianchi Bonomi" Hemophilia and Thrombosis Center, Institute of Internal Medicine, IRCCS Ospedale Maggiore,

University of Milan, and ${ }^{3}$ Neurology Department, Ospedale San Carlo, Milan, Italy

Stroke, 1996;27:1697.8 
In the young a large proportion of ischemic strokes, more than one third in a recent series (1), are eventually labelled as of undetermined etiology despite extensive investigations. Recently, a mutation in the gene coding for coagulation factor $\mathrm{V}$ (arginine to glutamine at position 506 ) has been associated with resistance to activated protein $C$ (APC): in its activated form, the mutant factor $\mathrm{V}$ is less sensitive to the inactivation by its naturally occurring inhibitor, activated protein $C(2)$. APC resistance caused by the factor $V$ mutation is the most frequent coagulation abnormality in patients with deep vein thrombosis of the lower limbs (3) or cerebral vein thrombosis (4). However, attempts to relate the mutation to arterial thrombosis have yielded conflicting results. A relationship between APC resistance and stroke was claimed first by Halbmayer et al (5) who found the abnormality in $20 \%$ of their 30 patients but only in $2 \%$ of the controls. However, other investigators failed to confirm these findings $(6,7)$, and Ridker et al (8) demonstrated in a prospective cohort study of 1408 individuals that factor $V$ mutation is not a risk factor for stroke in a population of American physicians older than 40 years.

In order to verify the association of factor $\mathrm{V}$ mutation and stroke in the young (in whom non-atherosclerotic causes predominate), we investigated ninety-five Italian patients aged less than 45 years who had experienced an episode of focal cerebral ischemia, as diagnosed by one of the three study neurologists, who evaluated their history and the presence of cerebrovascular risk factors. Fifty-one patients were admitted consecutively to the Ospedale Policlinico $(n=36)$ and Ospedale San Carlo $(n=15)$, while 44 had been referred consecutively to the Thrombosis Center from other hospitals for coagulation screening. All patients had undergone a CT or MRI scan, a cardiological examination and a continuous-wave Doppler examination of the neck vessels within two weeks of their attack. Sixty-five of them $(68 \%)$ had a duplex examination and $54(57 \%)$ had cerebral angiography; a transthoracic echocardiogram was performed in 83 patients $(87 \%)$ and was completed with transesophageal examination in 25 cases (26\%). According to the results of clinical and instrumental evaluation, cerebral ischemia was attributed to atherosclerosis, cardioembolism, small vessel disease, arterial dissection, migraine (when a patient with classic migraine suffered a stroke during a migraine attack), oral contraceptives (current use for at least three months), or considered to be of undetermined cause. A control group of 190 healthy subjects younger than 45 years was also investigated for the presence of factor $V$ mutation. Ninety-five of them were chosen from the general population and 95 were hospitalised for cardiac arrhythmia but had no history of arterial or venous thrombosis. Previous thrombatic events were excluded in controls using a structured questionnaire validated for its accuracy in the retrospective diagnosis of thrombosis (9). All subjects included in the study gave their informed consent.

DNA analysis for factor $V$ mutation was performed as previously described (10). Odds ratios (OR) were calculated by simple cross-tabulation and reflect the risk of cerebral 
ischemia when factor $V$ mutation is present, relative to the risk when it is absent. The $95 \%$ confidence intervals (CI) were calculated using the approximation of Woolf (11).

The clinical features of the 95 patients and the presumed pathogenetic mechanisms of their ischemic attacks are reported in Table 1.

Table 1. Age, sex, cerebrovascular risk factors, and etiology of the 95 patients with cerebral ischemia

\begin{tabular}{lll}
\hline Median ange (range) & 33 years $(5-44)$ & \\
Males/Females & $43 / 52$ & \\
Risk factors & Hypertension & $20(21 \%)$ \\
& Diabetes & $2(2 \%)$ \\
& Hypercholesterolemia $(>240 \mathrm{mg} \%)$ & $16(17 \%)$ \\
& Smoking & $40(42 \%)$ \\
Etiology & Large-artery atherosclerosis & $10(16 \%)$ \\
& Cardioembolism & $4(25 \%)$ \\
& Small vessel disease & $5(16 \%)$ \\
& Arterial dissection & $10(11 \%)$ \\
& Other & $11(12 \%)$ \\
& Undetermined & $25(26 \%)$ \\
\hline
\end{tabular}

Seventy-two $(76 \%)$ had had a stroke and $23(24 \%)$ a transient ischemic attack. Heterozygosity for the factor $\mathrm{V}$ mutation was detected in 4 of the 95 patients $(4.2 \%)$, compared with 3 of the 190 controls (1.6\%) (OR 2.7; 95\% CI 0.6-1.2.5). Homozygosity was not detected in patients or controls. Among the four patients with factor $\mathrm{V}$ mutation one had carotid artery dissection, and three patients had strokes of undetermined cause. Thus, among the 25 patients with stroke of undetermined cause, $3(12 \%)$ had the mutation as opposed to one of the 70 patients with a known cause (OR 9.4; 95\% Cl 0.9-95.2).

If factor $\mathrm{V}$ mutation is not a risk factor for cerebral ischemic attacks in an unselected population of young patients, may it nonetheless explain the occurrence of stroke in special cases? Ganesan et al suggested that the factor $V$ mutation may be a risk factor for stroke in children (12). We cannot comment on this, since only two children (5- and 6 -year-old) have been included in our study, and they had no factor $V$ mutation. Among our patients the prevalence of the factor $\mathrm{V}$ mutation was higher, albeit not significantly, in those who had no evident cause for stroke than among those with an etiologic diagnosis, suggesting a role for this coagulation defect in a subset of patients. This finding should be viewed with caution, since it stems from a retrospective analysis of a subgroup of patients. However, the hypothesis is worthy of confirmation in a prospective studly.

In summary, our results do not support the hypothesis that the factor $\mathrm{V}$ mutation responsible for resistance to APC is a risk factor for cerebral ischemia in an unselected 
population of young patients. Further investigations are needed to establish whether the detection of this coagulation abnormality may be of value in children and adults with stroke of undetermined cause.

\section{REFERENCES}

1. Adams HP Jr" Kappelle LJ, Biller J, Gordon DL, Love BB, Gomez F, Heffner M. Ischemic stroke in young adults. Archi Neurol 1995;52:49-15

2. Bertind RM, Koeleman RPC, Koster T, Rosendal FR, Dirven Rl, de Ronde H, van der Velden PA, Reitsma PH. Mutation in blood coagulation factor $V$ associated with resistance to antivated protein $C$. Nature 1994;369:64-7

3. Dahlback B. Ihetited thrombophilia resistance to activated protein $C$ as a pathogenic factor of venous thromboembolism. Blood $1995,85: 607-14$

4. Martinelli 1 , Landi $G$, Merati $G$, Cella E, Tosetto A, Mannucci PM. Fuctor $V$ gene mutation is a risk lactor lor cerebrat venous thrombosis. Thromb Hacmost 1996;75:393-4

5. Halbmayer $W-M_{n}$ Haushofer $A$, Schon $R$, Frischer $M$. The prevalence of poor anticoagulant response to activated protein C (APC resistance) among patients suffering from stroke or wenous thrombosis and among healthy subjects. Blood Coagul Fibrinol 1994;5:51-7

6. Catto A, Carter A, Irehand H, Bayston TA, Philippou $H$, Barret J, Lane DA, Orant PJ. Fuetor V Leiden gene mutation and thrombin generation in relation to the development of acute stroke. Stroke $1995 ; 15: 783-5$

7. Kontula K. Ylikorkala A, Mettinen H, Vuorio A, Kauppinen-Mikelin R Hämälänen L, Palomäki H, Kaste M Algs06 Glr factor $V$ mutation (factor $V$ Leiden) in patients with ischemic cerebrovascular disease and survivors of myocardial infarction. Thromb Haemost: 1995;73:558-60

8. Ridker PM, Hennekens CH, Lindpaintner K, Stampler MJ "Eisenberg PR, Miletich JP. Mutation in the gene coding coding for congulation factor $V$ and the risk of myocardial infarction, stroke, and vanous thrombosis in apparently healthy men. N Engl J Med 1995;332:912-7

9. Frezzato $M$, Tosetto A, Rodeghiero F. Validation of a questionnaire for the diagnosis of venotis thromboembolism. Br. J Hematol 1994:87:79

10. de Ronde H, Bettina RM. Laboratory diagnosis of APC-resistance: a critical evaluation of the test and the developmcat of diagnostie criteriat. Thromb Hemost 1994;72880-6

11. Woolf B. On estimating the nelation between blood group and disease. Ann Hum Gen 1955:19:251-3

12. Gunssin V, Kelsey H, Cookson J, Osbom A, Kirkham FJ Activated protein Cresistance inchildhood stroke Lanced 1996.347 .260 


\section{Chapter 7}

\section{HYPERHOMOCYSTEINEMIA AS A RISK FACTOR FOR DEEP-VEIN THROMBOSIS}

Marco Cattaneo, Ida Martinelli, Pier Mannuccio Mannucci

"A. Bianchi Bonomi" Hemophilia and Thrombosis Center, Institute of Internal Medicine, IRCCS Ospedale Maggiore, University of Milan, Italy

N Engl J Med 1996;335:974-5 
The article by den Heijer et al ${ }^{1}$ (March 21 issue) supports our original demonstration that hyperhomocysteinemia is a risk factor for deep-vein thrombosis independent of coexisting abnormalities of naturally occurring anticoagulants ${ }^{2}$. This important confirmation challenges the suggestion by Mandel et al, in their article in the same issue, ${ }^{3}$ that hyperhomocysteinemia increases the thrombotic risk only if the elevation in homocysteinemia is associated with the presence of factor V Leiden.

Unlike our study of patients with early-onset deep vein thrombosis ${ }^{2}$, and their previous study of patients with recurrent deep vein thrombosis ${ }^{4}$, den Heijer et al. reports on patients with a first episode of deep vein thrombosis who were younger than 70 years of age, in order to estimate the risk in the general population. Den Hejjer et al. may have underestimated the actual risk, because they measured homocysteine levels only in the fasting state. Patients with abnormalities of homocysteine metabolism, particularly those with abnormalities of the vitamin $\mathrm{B}_{6}$-dependent transulfuration pathway, may have normal homocysteine levels in the fating state but abnormal levels after oral methionine loading 5 . Patients with hyperhomocysteinemia after methionine loading are at increased risk for early-onset ${ }^{2}$ and recurrent ${ }^{4}$ deep vein thrombosis, and a substantial proportion (39-53\%) have normal homocysteine levels in the fasting state. It therefore remains to be established whether patients with hyperhomocysteinemia after methionine load are also at increased risk for first episodes of deep vein thrombosis.

We measured homocysteine plasma levels before and after oral methionine loading ( $3.8 \mathrm{~g}$ per square meter of body-surface area) in 89 consecutive patients with a first episode of objectively confirmed deep vein thrombosis and in 89 age- and sex-matched healthy controls. No subject had decreased serum concentrations of folate and vitamin $\mathrm{B}_{12}$. Homocysteine was measured in EDTA plasma by high-performance liquid chromatography and electrochemical detection ${ }^{2}$. There was a higher prevalence of hyperhomocysteinemia in the fasting state and after methionine loading in the patients with deep

Table 1. Prevalence of hyperhomocysteinemia in the fasting state and after methionine loading in 89 patients with a hirst episode of deep vein thrombosis and 89 controls*

\begin{tabular}{|c|c|c|c|c|c|c|}
\hline \multirow{3}{*}{$\begin{array}{l}\text { bomocysteine } \\
\text { level }\end{array}$} & \multicolumn{3}{|c|}{$>95$ th percentile } & \multicolumn{3}{|c|}{97.5 th percentile } \\
\hline & patients & controls & OR $(95 \% \mathrm{Cl})$ & patients & controls & OR $(95 \% \mathrm{CI})$ \\
\hline & \multicolumn{2}{|c|}{$n^{\circ}$ of subjects $(\%)$} & & \multicolumn{2}{|c|}{$n^{\circ}$ of subjects $(\%)$} & \\
\hline fasting state (1) & $7(7.9)$ & $4(4.5)$ & $1.8(0.5-6.4)$ & $5(5.6)$ & $2(2.2)$ & $2.6(0.5-13.7)$ \\
\hline $\begin{array}{l}\text { after methionine } \\
\text { londing (2) }\end{array}$ & $7(7.9)$ & $4(4.5)$ & $1.8(0.5-6.4)$ & $4(4.5)$ & $2(2.2)$ & $2.0(0.4-11.5)$ \\
\hline (1). (2), or boilh & $12(13.5)$ & $6(6.7)$ & $2.2(0.8-6.0)$ & $9(10.1)$ & $3(3.4)$ & $3.2(0.8-12.3)$ \\
\hline
\end{tabular}

* Hyperhomocysteinemia was defined using two cut-off points, the 95th and the 97.5 th percentile of the control distributions. The 95 th pencentiles were 18.8 mol per liter in the fasting state and 29.9 mol per liter after methionine loading. The 97.5 th percentiles were 24.1 mol per liter in the fasting state and 34.2 mol per liter after methionine loading. OR and $\mathrm{Cl}$ denote odds ratio and confidence interval. 
vein thrombosis than in controls (Table 1).

The data in Table 1 also show that since many of the patients with hyperhomocysteinemia after methionine loading had normal homocysteine levels in the fasting state, the combination of the two tests identified a larger number of patients with thrombosis and impaired homocysteine metabolism than either test alone. The detection of deep vein thrombosis in patients with hyperhomocysteinemia after methione loading has important clinical implications, since the metabolic abnormality may be corrected by vitamin supplements containing a high dose of vitamin $B_{6}$, in addition to folate and vitamin $B_{12}$.

\section{REFERENCES}

1. den Hejjer $M$, Koster $T$, Blom H, et al. Hyperhomocysteinemua as a risk factor for deep-vein hrombosis. N Engh J Med 1996;334:759-62.

2. Falcon CR, Cattaneo M, Panzeri D, Martinelli 1, Mannucei PM. High prevalence of typethomocyst(eynemia in patients with juvenile venous thrombosis. Arterioscler Thromb 1994; 14:1080 3.

3. Mandel H, Brenner B, Berant $M$, et al Coexistence of hereditary homocystinurin and factor V Leiden - Effect af thrombosis. N Engl I Med 1996; 334:763-8.

4. den Heijer M, Blom HJ, Gerrits WBJ, et al. Is hyperhomocysteinemin a risk factor for recurrent venous thombosis? Lancet 1995;345:882-5.

5. Rees MM, Rodgers GM. Homocysteinemia: association of a metabolic fisorder with vasculin disentse and thrombosis. Thromb Res $1993 ; 71: 337.59$. 



\section{Chapter 8}

\section{SUMMARY AND PERSPECTIVES}

The work presented in this thesis comprises a number of studies on hereditary thrombophilia, with the principal aim of investigating the clinical relevance of APC resistance (due to Arg to GIn mutation in activated factor V, factor V:Q506), the recently described genetic determinant of thrombosis. As our Thrombosis Center is specialized in the diagnosis of coagulation abnormalities predisposing to thrombosis, mainly young patients with unexplained events (i.e., free from neoplastic, autoimmune or systemic illnesses) are referred to us. This selected population represents a good model in order to study the genetic and environmental interactions, required to bring about thrombosis.

APC resistance and factor V:Q506 were first described by Dahlbäck and Bertina who found a very high prevalence of the defect (up to $7 \%$ ) in the general population of Northern Europe. A few months later, it became evident that the prevalence of the mutation differed in various ethnic populations and also in various countries. Rees et al (Lancet 1995;346:1133-4), reporting the distribution of mutant factor $V$ throughout the world, found that it was not present in Italians. Since this finding was probably conditioned by the small number of individuals tested, we investigated a cohort of 344 healthy Italians subjects (Chapter 2), and found a prevalence of heterozygous factor V:Q506 of $2.6 \%$, thus indicating that it was also present in Southern Europeans. Chapter 2 also shows that the association of factor V:Q506 with deficiency of the naturally occurring inhibitors confers an increased thrombotic risk, but the prevalence of combined defects was lower (3\%) than in Northern Europeans (19-38\%).

In Chapter 3 we wanted to determine the prevalence and clinical characteristics of APC resistance in 493 consecutive patients referred to our Thrombosis Center for a first episode of thrombosis occurring at a young age. The prevalence of APC resistance was significantly higher in patients than in healthy controls (15\% versus $2 \%$ ). The most frequent clinical thrombotic manifestation in APC-resistant patients was deep vein thrombosis. With the aim to make a direct comparison of the thrombotic risk and the 
clinical manifestation in individuals with $\mathrm{APC}$ resistance, antithrombin, protein $\mathrm{C}$ or protein $S$ deficiency, we carried out a study on more than 700 relatives of the index patients with one of the four defects (Chapter 3). The estimated risk was 9 to 12 times higher in carriers of deficiencies of the naturally occurring inhibitors, and only 4 times higher in those with APC resistance, than in non-carriers. The age at the occurrence of thrombosis was similar in the four defects, but patients with APC resistant had more episodes of superficial vein thrombosis. Considering that APC resistance is highly frequent in the general population and taking into considerations the molecular mechanisms of the defect (activated factor $\mathrm{V}$ is only partially resistant to the inactivation by activated protein $\mathrm{C}$ ), a lower thrombotic risk in comparison to deficiency of the naturally occurring inhibitors would be expected. On the other hand, it has been recently addressed that APC resistant patients have the same thrombotic risk of those with protein $\mathrm{C}$ deficiency, as assessed on the basis of the age at the occurrence of the first event. In addition, a state of biochemical hypercoagulability assessed by measuring the plasma levels of markers of coagulation activation, such as prothrombin fragment $1+2$ and thrombin antithrombin complexes, was identified in the same proportion of patients (one-third) with APC resistance and in any deficiencies of the naturally occurring inhibitors (Chapter 4).

A high prevalence of APC resistance was also found in patients with cerebral vein thrombosis, a rare but very harmful thrombotic manifestation (Chapter 5). The presence of acquired predisposing conditions (surgery, trauma, immobilization, pregnancy, oral contraceptives) was also evaluated; both the prevalence of the mutation (20\% versus $3 \%$ ) and oral contraceptive intake ( $75 \%$ versus $42 \%$ ) were significantly higher in patients than in controls. In contrast, the prevalence of APC resistance (as well as other hypercoagulable states) was not increased in patients with deep vein thrombosis of the upper extremities (Chapter 5). The most common risk factor for the so-called "primary" deep vein thrombosis of the upper extremities was strenuous muscular activity of the arms, which may precipitate thrombosis aggravating the extrinsic compression of the veins caused by pre-existing anatomic abnor malities. Hence, a laboratory screening for coagulation abnormalities should not be done in patients with thrombosis of the upper extremities.

The association between factor V:Q506 and venous thromboembolism has been clearly demonstrated by many investigators, with case-control or family studies. Surprisingly, (Chapter 5), we fonnd that its prevallence in patients with isolated pulmonary embolism (i.e., without a concomitant deep vein thrombosis of the lower extremity) was not as high (12\%) as in those with deep vein thrombosis complicated or not, by pulmonary embolism (23\%), and was not significantly higher than that found in healthy controls $(3 \%)$.

Whether or not factor V:Q506 is to be considered a risk factor for arterial thrombosis is still a matter of debate. Ridker et al ( $\mathrm{N}$ Eng J Med 1995;332:912-7) demonstrated in a 
large prospective study that the mutation was not a risk factor for stoke in a population of American physicians with a stroke after 45 years of age. As advancing age is a risk factor for thrombosis per se, the same conclusions may not be drawn for stroke in the young. Hence, we studied a cohort of patients who had a stroke at an age below 45 years (Chapter 6); an interesting observation was that, although the prevalence of factor V:Q506 was similar in patients and in controls (4.2\% and $1.6 \%$ ), factor $V: Q 506$ was mostly present in the subgroup of patients with criptogenetic stroke, i.e., without any apparent cause (12\%), suggesting a possible role in this special cases.

As regarding arterial thrombosis, it is known that elevated plasma homocysteine levels are associated with an increased risk of stroke, myocardial infarction, peripheral artery disease, and extracranial arterial thrombosis. More recently, the evidence that hyperhomocysteinemia is a risk factor also for venous thrombosis has been provided by several studies. In Chapter 7 we reported that the prevalence of hyperhomocysteinemia in 89 consecutive patients with deep vein thrombosis of the lower extremities was higher $(13.5 \%)$ than in healthy controls $(6.7 \%)$. Furthermore, we underlined the importance to measure homocysteine levels in the fasting state and after a methionine loading, since the combination of the two tests identified a larger number of patients with thrombosis and impaired homocysteine metabolism than either test alone.

There is the evidence that patients with a certain coagulation defect develop thrombotic symptoms of varying severity. A discrepancy in clinical expression has been observed for example in protein $\mathrm{C}$ deficiency, which may be clinically recessive and clinically dominant. Since this discrepancy could not be explained by different mutations underlying the defect, the most plausible explanation arose from the view that more than one abnormality may be required to cause thrombosis. It has been shown that when APC resistance is present with deficiency of protein $C$, protein $S$ or antithrombin in the same individual, it causes a higher thrombotic risk than each of these abnormalities separately. So, from a concept of thrombophilia due to a single gene defect, at the present time it is accepted that in some families the co-segregation of two genetic defects can occur and then thrombophilia is a multiple gene disorder. It is likely that genetic defects particularly frequent in the general population may aggravate the risk of thrombosis, more than carrying a high risk per se. This also explains the high risk of thrombosis among non-deficient family members with respect to the general population; many of them may carry APC resistance, or hyperhomocysteinemia, or the newly identified mutant prothrombin (due to a point mutation in the 3 '-untranslated region of prothrombin [20210 AG] that accounts for approximately $10 \%$ of the cases), or other genetic defects still unknown. An explosion of knowledge on thrombophilia has been verified in the last few years, but all genetic influences and their interaction are not yet understood, since even in patients from families selected on the basis of a high number of unexplained thromboses, only in about half an underlying defect will be found. 


\section{Curriculum Vitae}

Ida Marianna Martinelli è nata a Milano il 29 giugno 1963. Dopo la maturità Scientifica si è laureata nel 1988 in Medicina e Chirurgia all"Università Statale di Milano con pieni voti e la lode.

Presso la stessa Università ha ottenuto nel 1991 la Specializzazione in Ematologia con pieni voti e la lode e nel corrente anno terminerà il corso di studi per la Specializzazione in Medicina Interna.

Dal 1987 frequenta il Centro Emofilia e Trombosi "Angelo Bianchi Bonomi" diretto dal Prof. P.M. Mannucci all'Ospedale Maggiore Policlinico di Milano, occupandosi prevalentemente di pazienti con trombosi e svolgendo attività di ricerca nello stesso ambito, con particolare riguardo alla trombofilia ereditaria. Nel 1994 ha trascorso in qualità di Senior House Office un periodo di lavoro presso il Haemophilia Centre al Churchill-John Radcliff Hospital di Oxford, UK, diretto dal Dr. P.L.F. Giangrande. Dallo stesso anno svolge la propria attività in qualità di Assistente Ematologo al Centro Emofilia e Trombosi dell'Ospedale Maggiore Policlinico di Milano. 